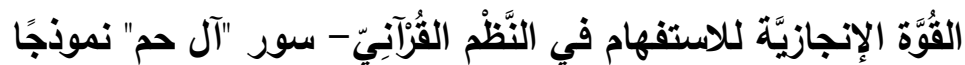

\title{
مقدمة
}

يأتلف عنوان البحث من ثلاثة عناصر مُوَسِّسَةِة، أولها-الاستفهام، وثنانيها-

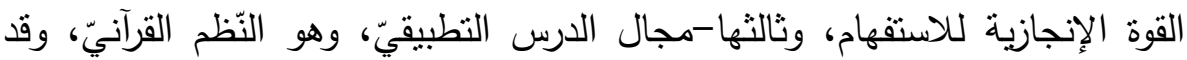

$$
\text { خصصته بـ"سور آل حم". }
$$

يعتمد الاستقهام بوصفه وسيلةً تخاطبيةً على أبرز أدوات التخاطب، منل:

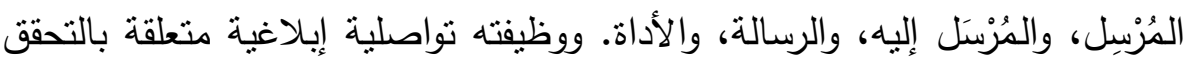
وعدمه، تصورًا وتصديقًا.

ولا يقف الكثف عن معنى الاستقهام عند حدود البنية، بل يتجاوزها إلى أحوال الاستعمال؛ لأن معناه يتمثل في "تاوله" بين السائل والمخاطب في السياقات المختلفة، وفق أغراض المتكلمين وأحوال المخاطبين. وهو نوعان: مباشر غرضنه لانه

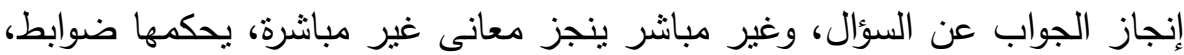
من أهمها- السياق، وقصد المتكلم، والعرف اللغويّ...إلخ. وللاستفهام قوة إنجازية مباشرة وغير مباشرة، تتفاوت شدةً وضعفًا وَفْقَ الوسائل اللغوية وغير اللغوية. ويكثف مفهوم القوة الإنجازية عن العلاقة الوثيقة بين

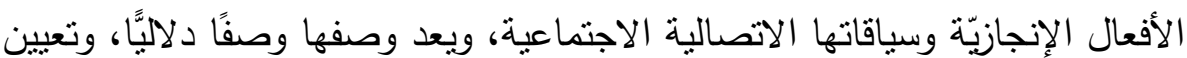

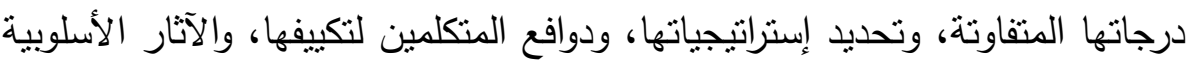
الناجمة عن ذلك التكييف- من المداخل اللسانية التداولية الضرورية لتحليل الخطاب الأدبيّ وغير الأدبيّ في سياقاته الاتصالية الحقيقية. (') أما مجال الدرس التطبيقيّ فقد خصصئه بسور "آل حم" لأسباب، منها:

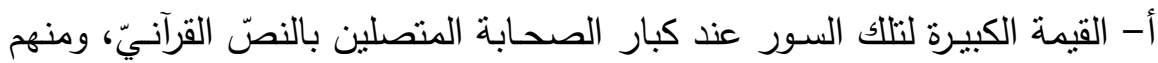

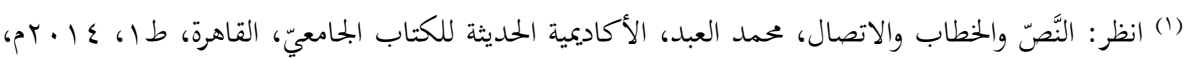
صع بr، وفي البراجماتية، الأفعال الإنحازية في العربية المعاصرة- دراسة دلالية ومعجم سياقيّ، د.علي محمود

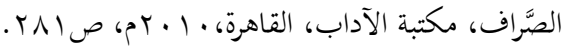


عبد الهه بن مسعود في قوله: "آل حم ديباج القرآن"، وابن عباس في قوله: "إن لكل

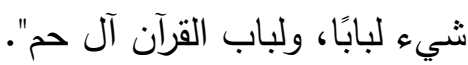
ب- أنها ثقز أصولا تتاسبية في التفكر وعدم الجدال القائم على ضمور المعرفة وتضخم الهوى مع كون العربية لسانًا وليست جنسًا، وأنها تجمع بين الوعد والوعيد، والثدة والرفق، وتحمل ذكرًا لموسى وهود وصالح ولوط -عليهم السلام-، وتمزج بين عالمي الجن والإنس في سباق حواريّ وسردي” ماتع.

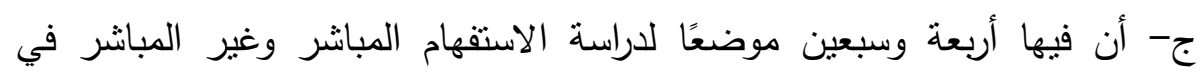

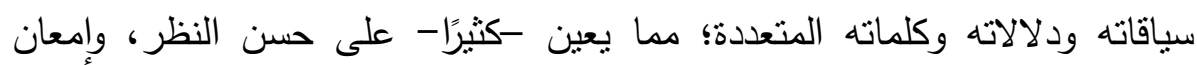
(r) (التذبر (

$$
\text { وتتمثل أسباب اختيار البحث في: }
$$

1- أهمية نظرية الأفعال الكلامية (الأفعال الإنجازية)؛ إذ تنتأثر باهتمام الباحثين

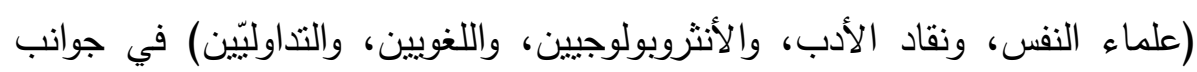
النظرية العامة لاستعمال اللغة. r- الوقوف على مفهوم الأفعال الإنجازية المباشرة وغير المباشرة، واستخلاص محدات أو ضوابط كل منهما، وبيان موضع الاستفهام في تصنيفات المحدثين لتأغراض الإنجازية الكبرى. r- وضع شروط أو ضوابط للاستفهام المباشر، وغير المباشر ذي الدانلات الإنجازية الضدنية التي ترتبط بتجدد الاستعمال اللغويّ في مختلف السياقات التداولية ولية الاتصالية في النظرية الإنجازية. ع - دراسة القوة الإنجازية للاستفهام في الاستعمال والتواصل من حيث: مفهومها، وعناصرها، وعلاماتها والفرق بين القوة والغرض، وإستراتيجيات تعديلها: تقويةً وإضعافًا، ووسائل تعديلها.

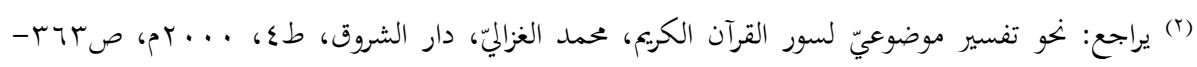

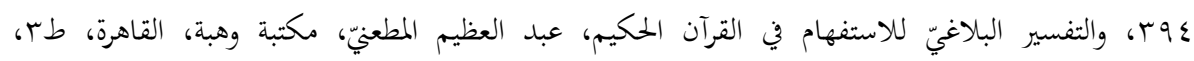


0- الوقوف على مفهوم القوة الإنجازية، وتتوعها، ووسائل تقوية إنجاز الاستفهام في النظم القرآنيّ ولاسيما سور آل حم-، والكثف عما يمكن أن يضيفه إلى تصور المحدثين. צ- الكثف عن القوى التعبيرية الإنجازية المتضمنة في الاستقهام في النظم القرآنيّ ولاسيَّما سور آل حم - وعن تفاوتها شدةً وضعفًا، ووسائل تقويتها، وسبب التعبير عنها لإيها

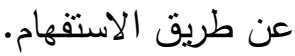
V - استتباط دوافع ميل النظم القرآنيّ -لاسبِيَّما في سور آل حم- إلى استعمال

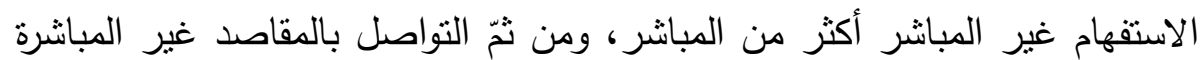

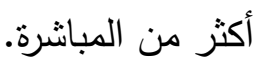
وقد بنيت الدراسة على استقراء شواهد الاستفهام الواردة في سور "آل حم"،

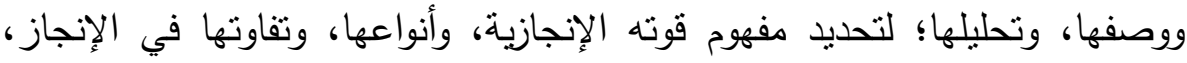
ووسائل تعديلها، وتحديد القوة الإنجازية للاستفهام المباشر، والقوى الإنجازية لغير المباشر في سور آل حم، وما تتضمنه كل منها من معنى ثانويّ.

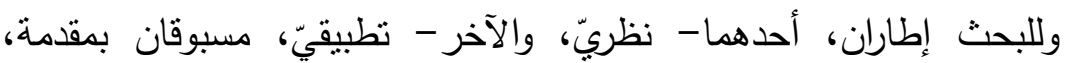
ومذيلان بخاتمة، وقائمة بالمصادر والمراجع، وفهرس المحتويات.

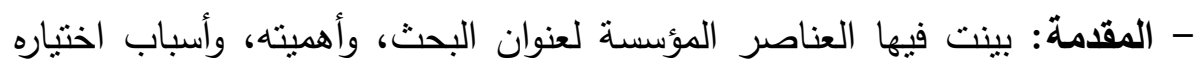

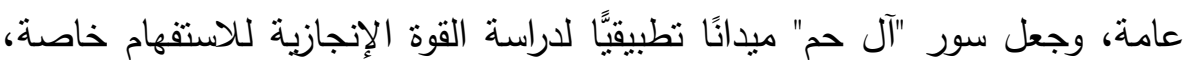
ومنهج الدراسة. - الإطار النظريّي: قسمته مبحثين، المبحث الأول، وعنوانه- "الأفعال الكلامية بين

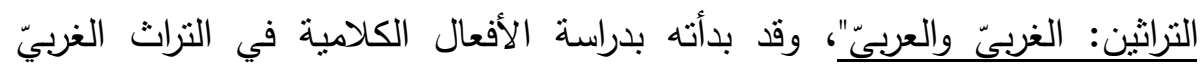

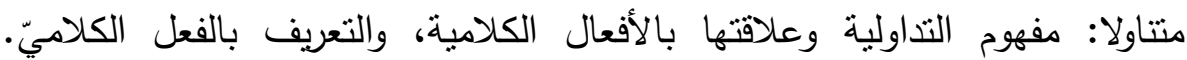

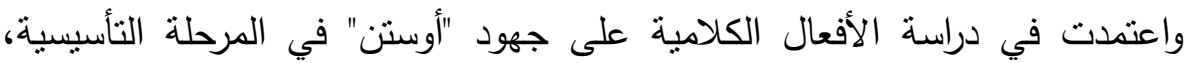
و "سيرل" في مرحلة الضبط المنهيّ. وثثيت بدراسة الأفعال الكلامية في النراث

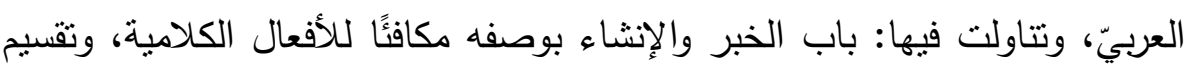
الكلام إلى خبر وإنشاء، ثم العدول عنه إلى تقسيم الأفعال إلى أفعال إيقاعية، وأفعال

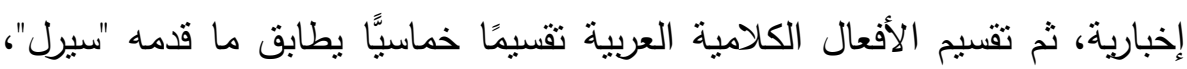


ويفيد من بعض ضوابطه. ثم أشرت إلى تصور العلماء العرب -من بلاغيين

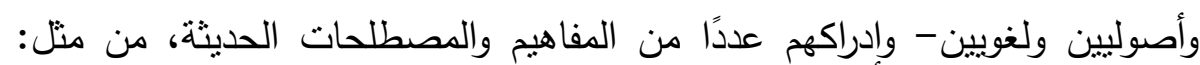
الفعل اللفظيّ والفعل الإنجازيّ، والأفعال الكلامية المباشرة وغير المبنية والمباشرة، وأهم

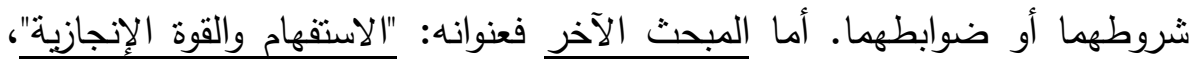
وتتاولت فيه: مفهوم الاستقهام، وعلاقته بالأفعال الكلامية، وتقسيمه إلى مباشر وغير الثير مباشر، ومفهوم كل قسم منهما، وأهم ضوابطه وشروطه. ثم تناولت مفهوم القوة الإنجازية، والفرق بين القوة والغرض، وامتلاك الغرض الإنجازيّ الواحد قوى تعبيرية عدة، وعلامات القوة الإنجازية للفعل، وإستراتيجيات تعديل القوة الإنجازية ووسائله.

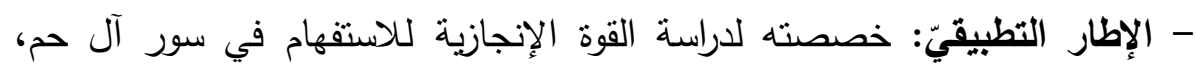

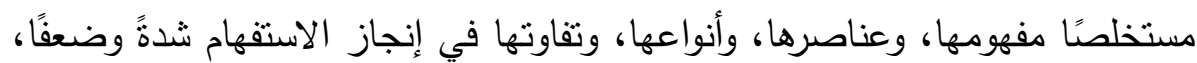
وبعضًا من وسائل تقويته. - الخاتمة: تتضمن أهَّ ما توصلت إليه الدراسة، ثم قائمة بالمصادر والمراجع، وأخيرًا فهرس المحتويات.

\section{الإطار النظريّ}

قسمت الإطار النظريّ للاراسة إلى مبحثين، الأول عنوانه: "الأفعال الكلامية بين التراثين: الغربيّ، والعربيّ"، أما الآخر فعنوانه "الاستقهام والقوة الإنجازية".

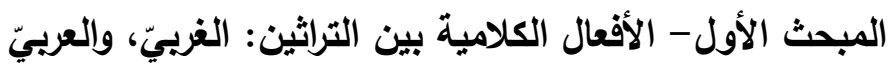

$$
\text { أولا- الأفعال الكلامية في التراث الغربيّ }
$$

تعد التذاولية Pragmatics من أبرز نظريات اتجاه عُني بدراسة اللغة في الاستعمال والتواصل، ودور المقام وما بتصل به من قرائن غير لفظية- بعد أن كانت

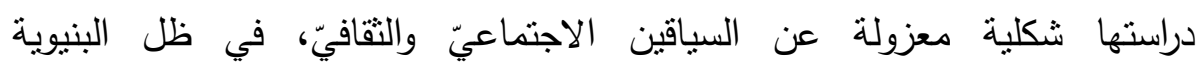

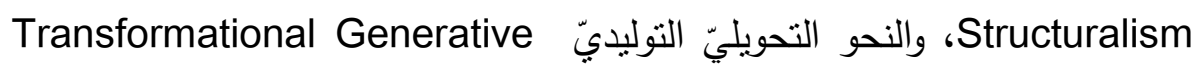
Grammar

Helbig. G. (1990): Entwicklung der Sprachwissenschaft seit 1970, Westdeutscher () Verlag GmbH. Opladen. S.179. Green, K. \& Lebhan, J. (1996): Critical Theory\& practice, (London/New York) p. 25f. 
بأنها: "دراسة اللغة في الاستعمال in Use أو في التواصل interaction

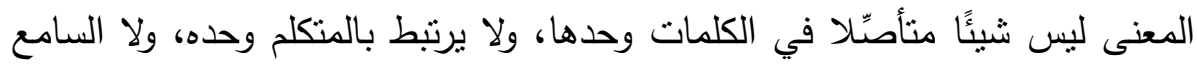

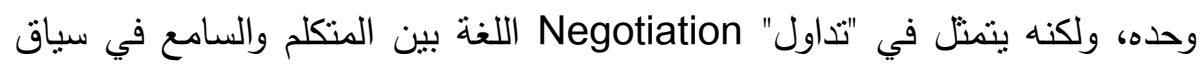

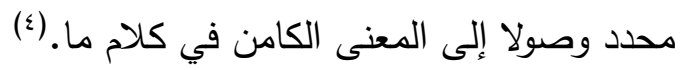

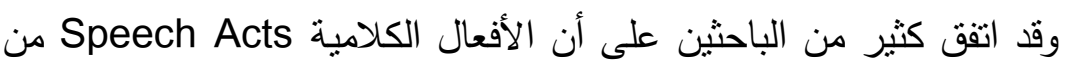

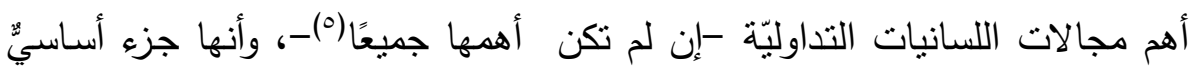

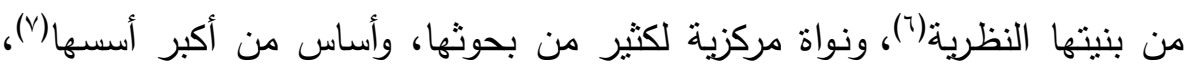

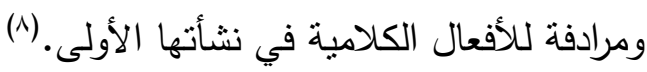
ويُعرَّنُ الفعل الكلاميّ بأنه "التصرف أو العمل الاجتماعيّ أو المؤسساتيّ الذي ينجزه الإنسان بالكلام، ويراد به الإنجاز الذي يؤديه المتكلم بمجرد تلفظه بألفاظ

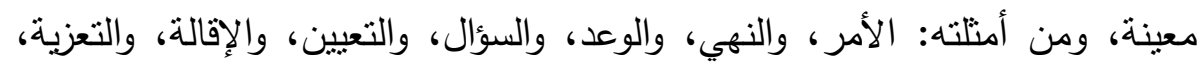

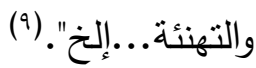
وقد ركزت في تتاول الأفعال الكلامية في التراث الغربيّ على جهود "أوسنن"

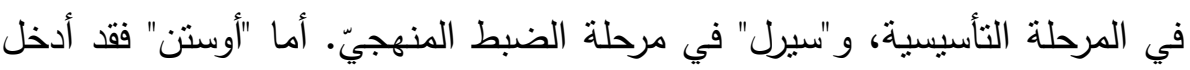
مفهوم "القصدية" في تحليل العبارات اللغوية، وذللك حين ربط بين التراكيب اللغوية وغرض المتكلم أو المقصد العام من الخطاب. وحدد خصائص الفعل الكلاميّ بأنه:

Thomas. J. (1996): Meaning in Interaction. An Introduction to Pragmatics. Longman, London and New York. p. 22.

Levinson. S. C. (1983): Pragmatics. Cambridge University Press. P.226.

$$
\begin{aligned}
& \text { (1) انظر: النَّصّ والسياق- استقصاء البحث في الخطاب الدلاليّ والتداوليّ، فان ديك، ترجمة عبد القادر قنينيّ، }
\end{aligned}
$$

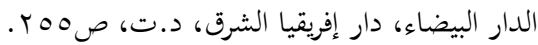

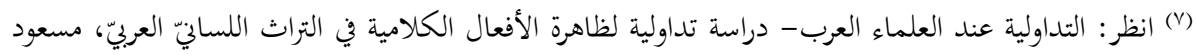

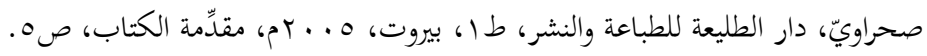

Bussmann. H. (1996): Dictionary of Language and Linguistics. Translated and edited by Trauth. G.P. and Kazzazi, K. Routledge. London\& New York. P. 374.

(9) التداولية عند العلماء العرب، مقدِّمة الكتاب، ص • . . . . 
دالٌ، وإنجازيّ ينجز الأشياء والأفعال الاجتماعية بالكلمات، وتأثنيريّ ينرك آثارًا معينة

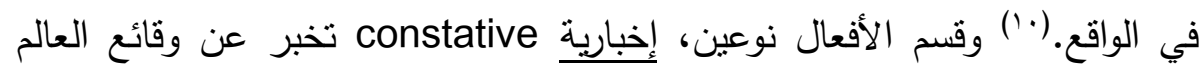
الخارجي، وتعرض أقوالا كالإثبات والتقرير والإعلان، ويمكن الحكم عليها قضوعيًا بالصدق أو الكذب، وأدائية performative يقترن النطق بها بأداء الفعل أو إنجازه، كالوعد والتحذير والأمر، ولا توصف بصدف ولا كذب، بل تكون موفقة happy أو

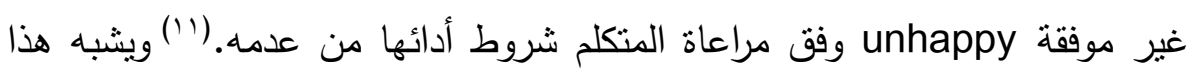
تقسيم الفارابيّ العبارات الكلامية إلى: عبارات القول، وعبارات الفعل.(ז'أ) ثم قدم "أوستن" الأفعال الأدائية إلى: صريحة Explicit، يكون الفعل فيها صريح الدلآلة

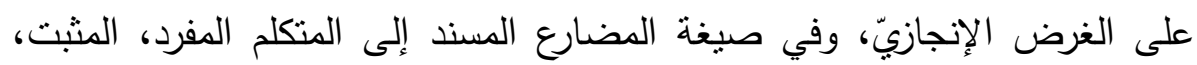

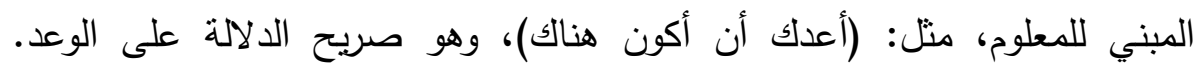

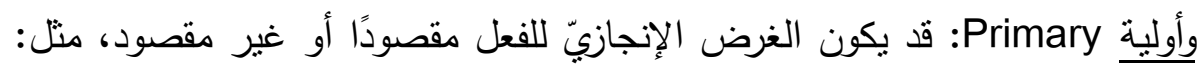

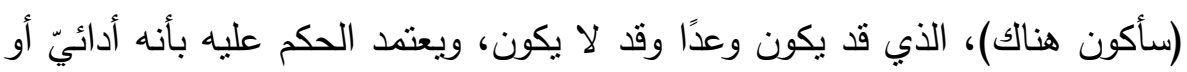

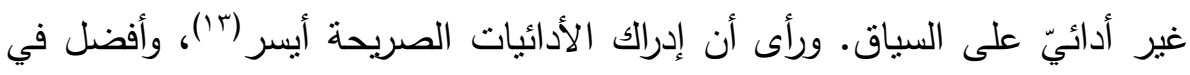
التعبير عن المراد إنجازه؛ إذ نستخدم صيغة مباشرة ليست بحاجة إلى تأويل، وتعلن إنى الئن

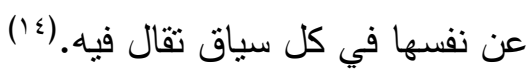
ورأى أن الفعل الكلاميّ مركب من ثناثة أفعال، تمثل جوانب مختلفة لفعل كلاميّ

(·(1) السابق نفسه: صـ-9،، وصعــ. ومن خصائصه: أنه فعل لفظيّ، وإنسانيّ، وقصديّ، وله معنى قابل

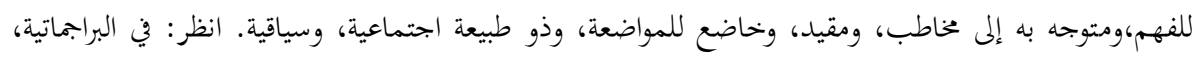

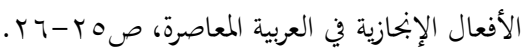

Austin. J. L. (1962): How to do Things with Words, Harvard University Press, P. 6.

والتحليل اللغويّ عند مدرسة أكسفورد، صلاح إسماعيل عبد الحق، دار التنوير للطباعة والنشر، بيروت، طال،

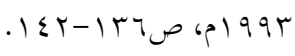

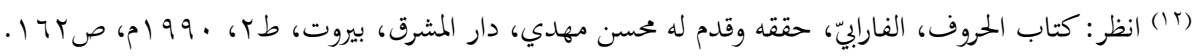
Austin. J. L. (1962), P. 57.59.

Geis, M, L. (1997): Speech act and Conversational Interaction. Cambridge University Press. P.5f. 


$$
\text { واحد، وهي (10): }
$$

1- الفعل اللفظيّ locutionary act: يتكون من النطق بأصوات لغوية، ينتظمها تركيب نحويّ صحيح، ينتج عنه معنى محدد، وهو المعنى الحرفيّ أو الأصليّ المفهوم من التركيب. r- الفعل الإنجازيّ الفيّ" يقصد به ما يؤديه الفعل اللفظيّ من وظيفة في الاستعمال، مثل: النصح، والأمر ، والتحذير، والوعد....إلخ.

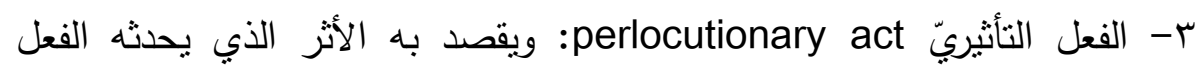

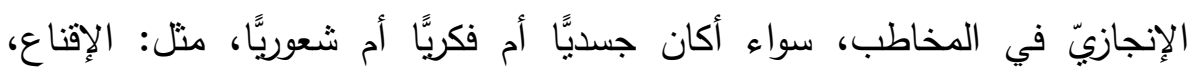
والتضليل، والتخويف...إلخ.

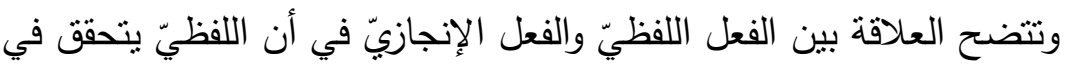
ألفاظ أو تعبيرات لغوية ذات دلالات مرجعية إحاليَّة، أما الإنجازيّ فيتحقق في ألفاظ أو تعبيرات لغوية تتطوي على قوى إنجازية تمثل القصد التداوليّ من تحقيق الفعل

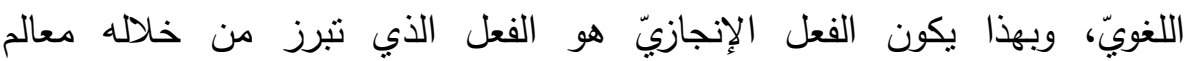

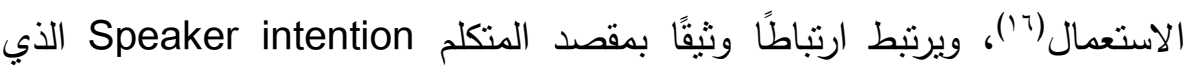
يعبر عنه بالإنجاز ، ويقوم بدور مركزيّ في نظرية الفعل الكلاميّ.

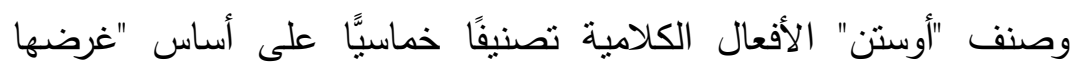
الإنجازيّ"illocutionary Force إلى أفعال: الأحكام Verdictives، والقرارات Exercitives

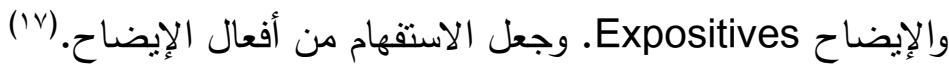

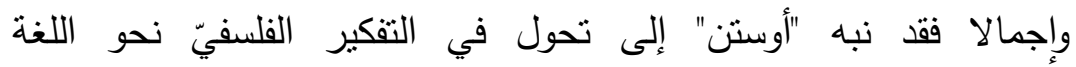
واستعمالاتها، وأدخل في البحث الدلاليّ ضرورة الاعتماد على السياق والموقف

Austin. J. L. (1962), P. 101ff. Helbig, G. (1990), S.185. 
الاتصاليّ، وربط التحليل اللغويّ بالاستعمال وليس ببنية اللغة.(^)" وميز بين محاولة أداء الفعل الإنجازيّ والنجاح في أداء هذا الفعل، وما تعنيه الجملة وما قد يعنيه

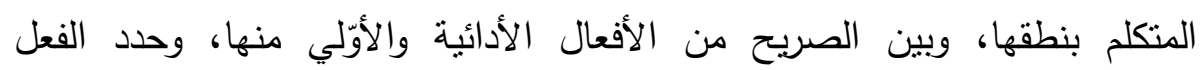

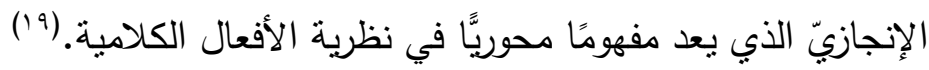
أما "سيرل" فقد أعاد النظر فيما قدمه "أوستن" من تصور لنظئا لنظرية الأفعال

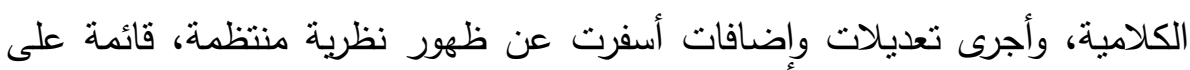

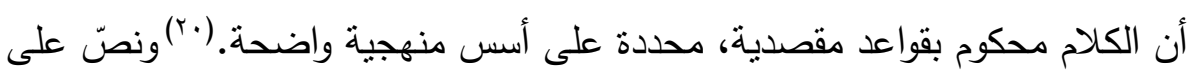

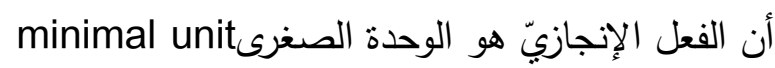

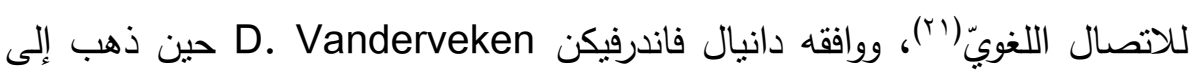

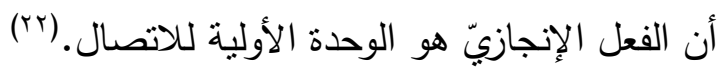

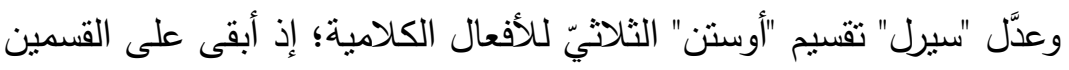

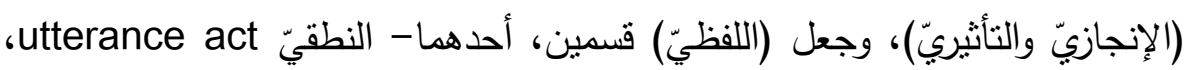

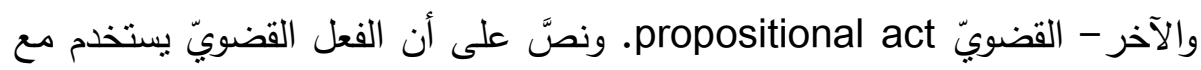
فعل إنجازيّ؛ لأنك لا تستطيع أن تتطق بفعل قضويّ من دون أن يكون للك مقصد

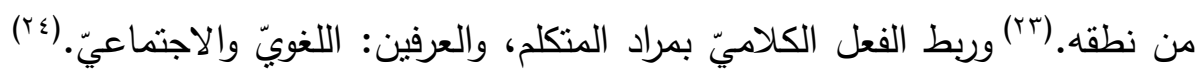

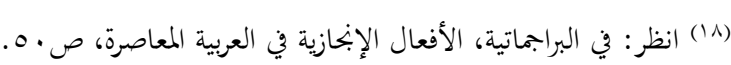

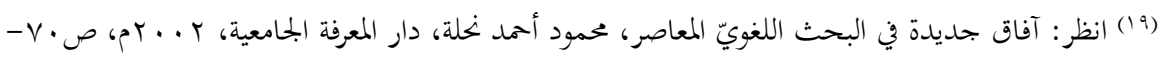

$$
\begin{aligned}
& \text {. } v 1 \\
& \text { (r) (r) السابق نفسه: صVاء. }
\end{aligned}
$$

Searle. J. R. (1969): Speech Acts. An Essay in the philosophy of language.

Cambridge University Press, p. 39. Leech, G \& Thomas, J. (1990): Language, Meaning and context: Pragmatics, in: Collinge, N.E (ed): An Encyclopedia of Language. Routledge London and New York. p.177.

Vanderveken, D. (1990): Meaning and Speech Acts. Vol.1: Principles of

Language, Cambridge University, Press, p.7.

Searle. J. R. (1969), pp. 24-25.

Leech, G \& Thomas, J. (1990), p.177. 
ثم صنف المجالات الأساسية للأفعال الكلامية على النحو الآتي: الإخباريات Assertives و مالتوجيهيات Directives، والالتزاميات Commissives، والتعبيريات Expressives، والإعلانيات Declarations. وجعل الاستقهام في التوجيهيات إن كان بصورته المباثرة.(ro) وخطا "سبرل" خطوةً أخرى -بعد تفريق "أوستن" بين الأفعال اللفظية والإنجازية، والإنجازية الصريحة والأولية- إذ ميز بين الأفعال الإنجازية المباشرة direct illocutionary act

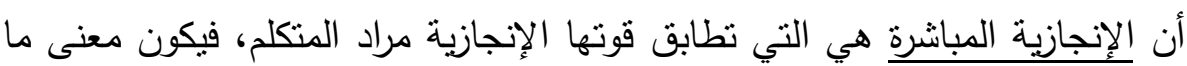

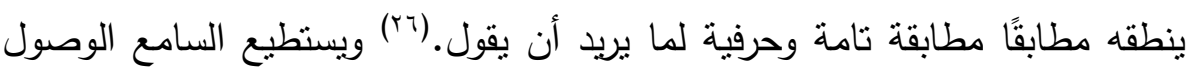

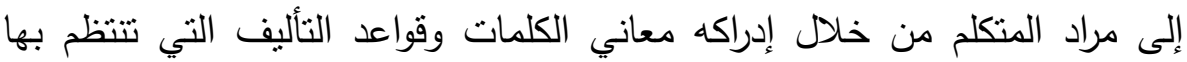

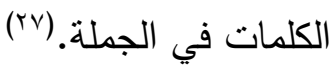

ويرى "ستانلي فش" أننا إذا وجدنا توافقًا بين التركيب والوظيفة التوصيلية

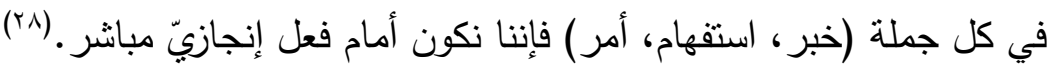

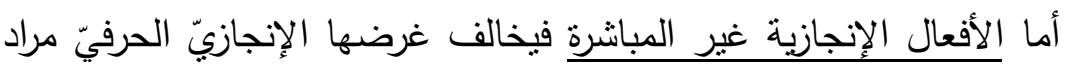

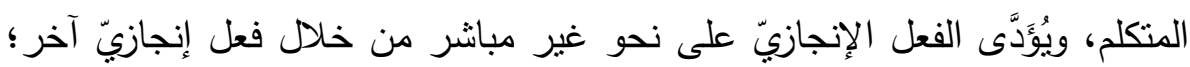

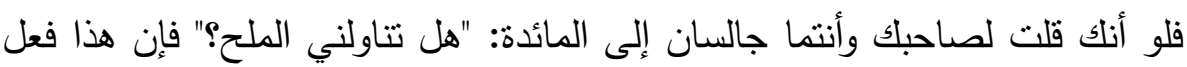
إنجازيّ غير مباشر؛ إذ معناه الحرفيّ الاستقهام، وهو مصدر بالاليل الإنجازيّ illocutionary indicator يجيك صاحبك بـ"نعم" أو بـ"لا"، بل مرادك أن تطلب منه طلبًا مهذبًا أن يناولك

Searle. J. R. (1981), Expression and Meaning. Studies in the Theory of Speech Acts, Cambridge University Press. P.12ff.

Ibid, P.30.

Ibid, P. 117.

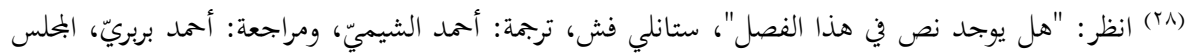

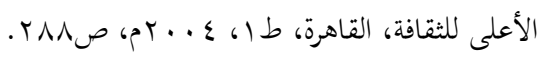


الملح.(r9)وقد نبه "سيرل" إلى أن المتكلم لا يقصد ما يقول فقط، بل يتعدى قصده ما

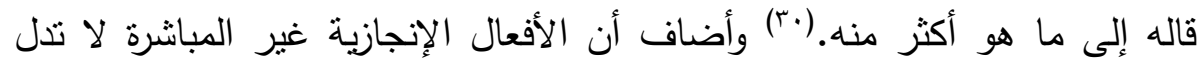

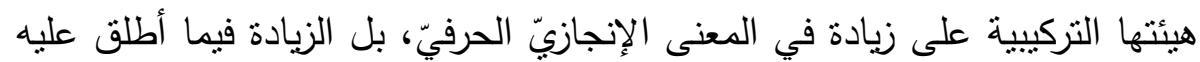

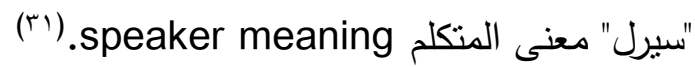
ويُعَنُِّ التفاوت الواضح في في أفعال الكلام غير المباشرة- بين القول والمقصد، أو بين معنى قضويّ والفعل الذي ينجزه المتكلم في السياق - إنشالية مركزية في تداولية

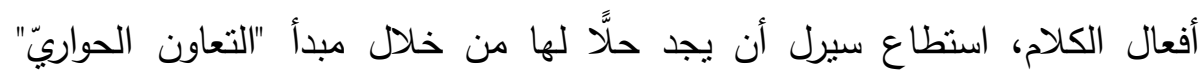
conversational cooperation

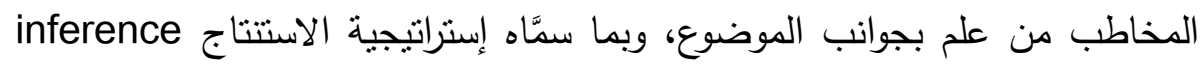
strategy خطوات من الاستدلال. (r) (r) ورأى "سيرل" أن أهم بواعث استخدام الأفعال الإنجازية غير المباشرة-

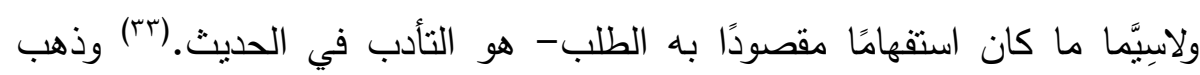

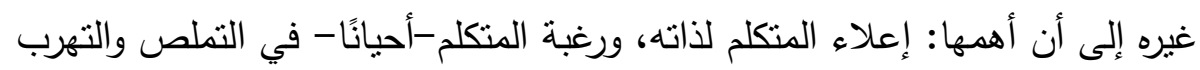

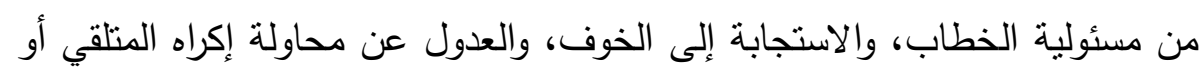
إحراجه لإنجاز فعل قد يكون غير راغب في إنجازه، والاستغناء عن إنتاج عدد من ولن إناه

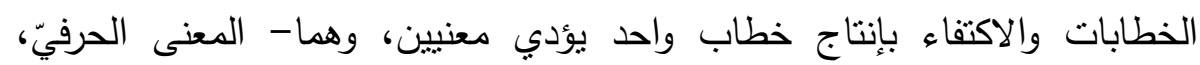

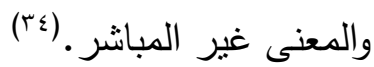
ثانيًا- الأفعال الكلامية في التراث العريّي

Searle. J. R. (1981), P.30. Lyons. J. (1996): Linguistic Semantics. An ( $(9)$ Introduction. Cambridge University Press. P.93f.

Searle. J. R. (1981).p.30.

Ibid. p.42.

Ibid. pp.46, 49.

Searle. J. R. (1981). P. 48,

Leech, G. (1983): Principles of Pragmatics. Group limited. London. p.107. 
إن المعاني المستفادة من الأساليب العربية ودلالات"حروف المعاني" و "الخوالف"- هي التي تمثل الأفعال الكلامية في التراث العربيّ؛ لأنها ذات "دلالات التات

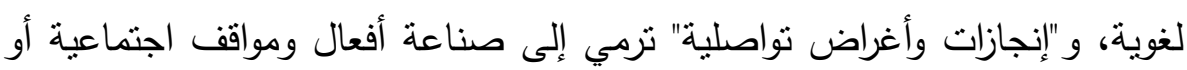
فردية بالكلمات، وإلى التأثير في المخاطب: بحمله على فعل أو تركه أو دعوته إلى لى إلى

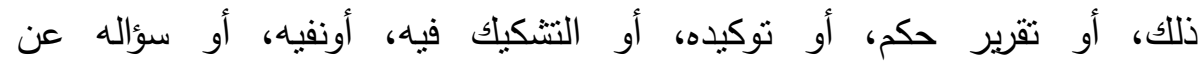

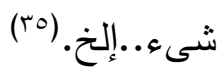
ومن الباحثين من عدّ باب "الخبر والإنشاء" يعادل مفهوم "الأفعال الكلامية"

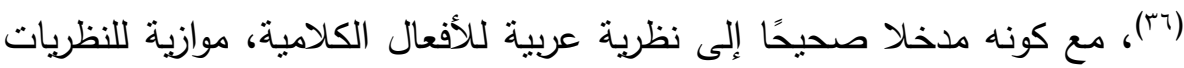

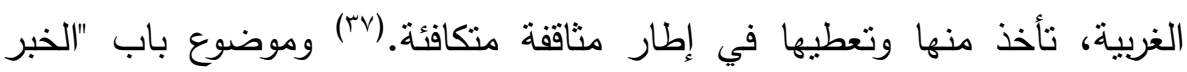
والإنشاء" نتبع خواص تراكيب الكلام المستتبطة من التركيب والسياق الذي توظف ونف

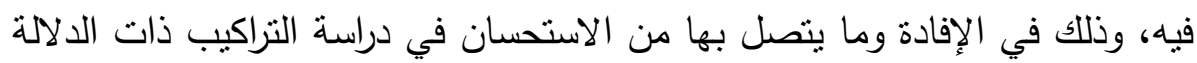

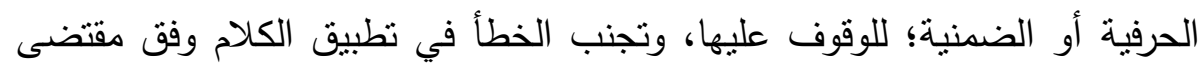

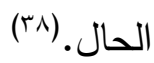
وقد رؤي تقسيم الكلام -وَفْقَ المعنى المراد- إلى خبر وإنشاء (وَ) ثم عدل

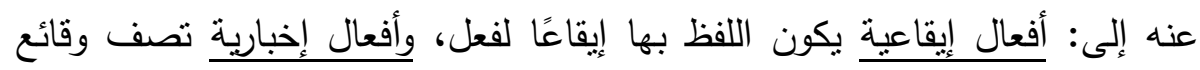

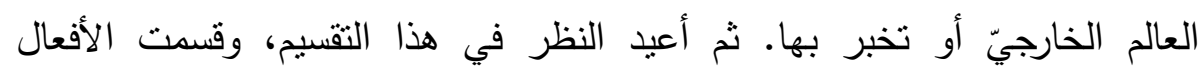

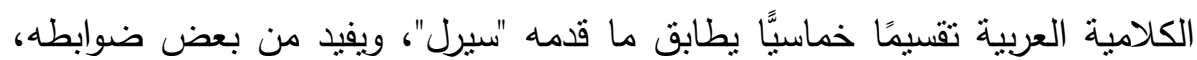
واستبدل فيه "الإيقاعيات" و "الطلبيات" بما أطلق عليه "سيرل" (الإعلانيات) و (التوجيهيات)؛ لانسجامهما مع طبيعة الاستعمال في اللغة العربية، وذلك على النحو

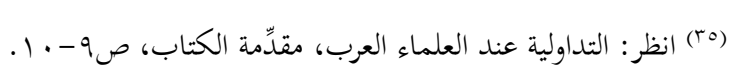

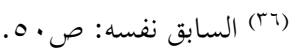

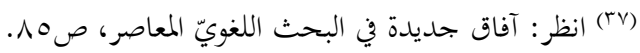

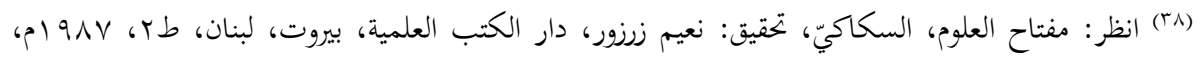

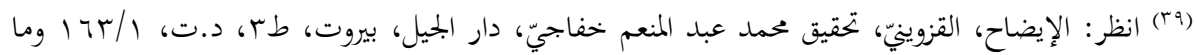


الآتي: الإيقاعيات، والطلبيات (ومنها الاستفهام)، والالتزاميات، والإخباريات،

والتعبيريات.(•)

الفعلان: اللفظيّ والإنجازيّ في تصور العلماء العرب

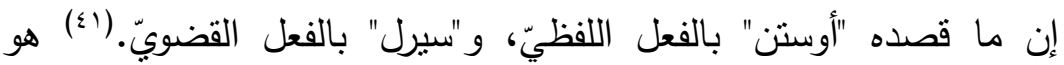

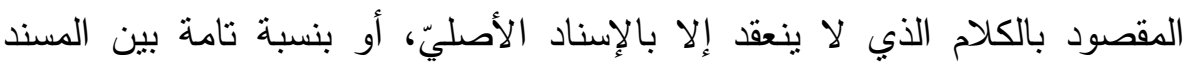

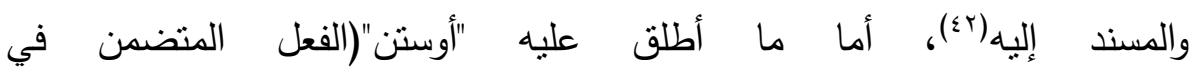

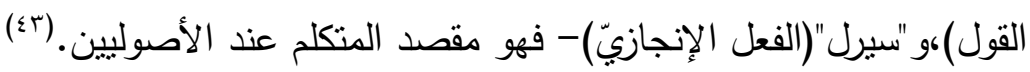

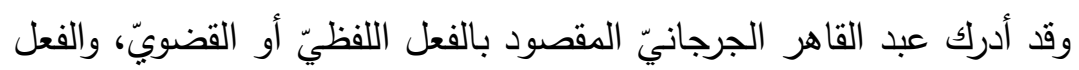

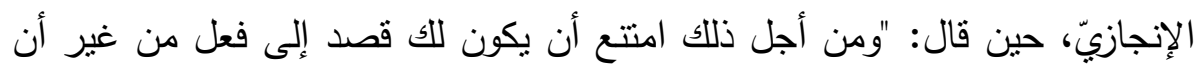

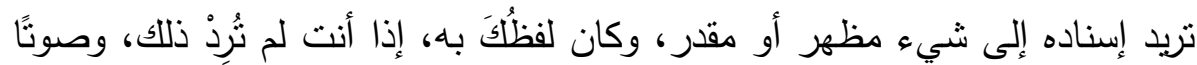

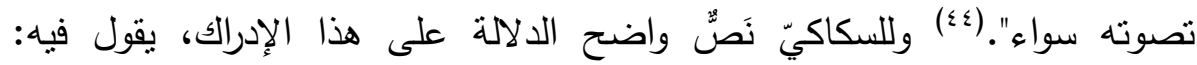
"...وأعني بالفهم فهم ذب الفطرة السليمة، منل ما يسبق على فهمك من تركيب: (إنَّ

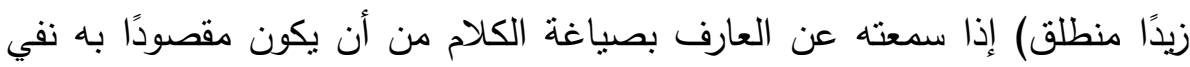

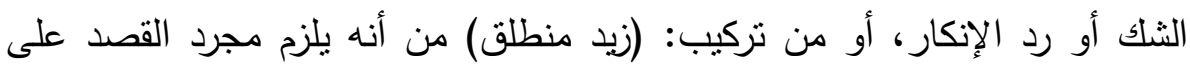

الإخبار ...". (؛0)

والحق أن علماء الأصول أدركوا ما لم يدركه "سيرل" وأستاذه؛ إذ قسَّموا الكلام الذي يحمل مقصود المتكلم -من حيث وضوح الدلالة- إلى: واضح وغير لإن

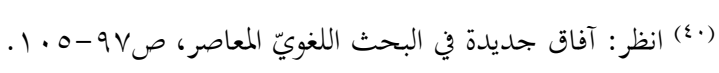

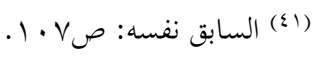
(rأ) انظر: شرح الكافية، رضيّ الدين الإستراباذيّ، تصحيح وتعليق يوسف حسن عمر، جامعة قار يونس، بنغازيّ، طب، 1999 ام. (2r) انظر: البرهان في علوم القرآن، الزركشيّ، تحقيق محمد أبو الفضل إبراهيم، دار إحياء الكتب العربية، طا، .

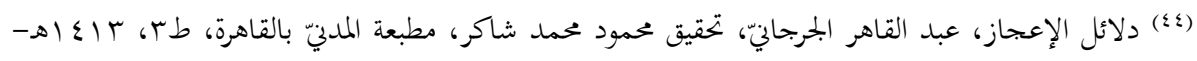
$.0 T V / 1601994$ 
واضح، وقسموا الواضح إلى: محكم، ومفسر، ونص، وظاهر، وغير الواضح إلى:

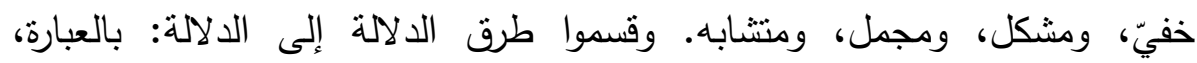

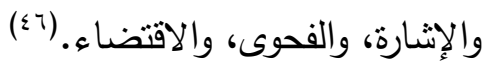

\section{الأفعال الكلامية المباشرة وغير المباشرة: تصور العلماءع العرب لها، مفهومها؛}

\section{ومحدد|تها}

لعل أقرب مصطلحين بلاغيين يقابلان الأفعال الكلامية المباشرة وغير

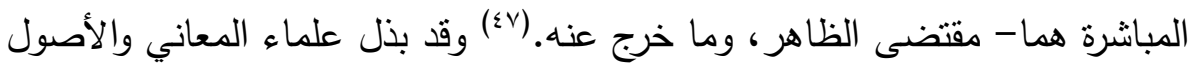
واللغة جهذًا في تحديد المعاني الخارجة عن مقتضى الظاهر . أما علماء المعاني فأدركوا مفهوم الأفعال الكلامية ذات المعنى الأصليّ أو الحرفيّ إدراكًا واضحًا، وحدد العداء

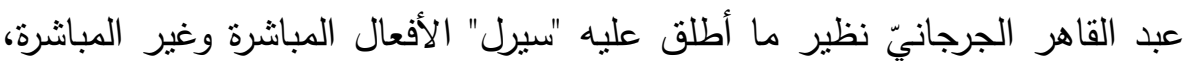

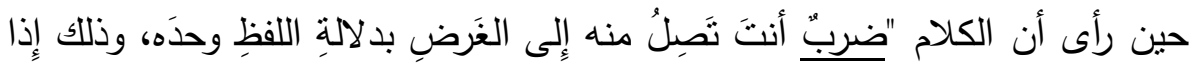

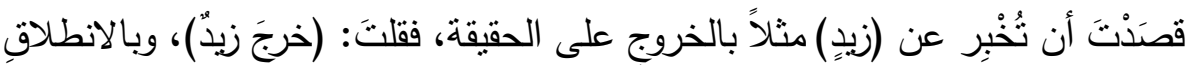

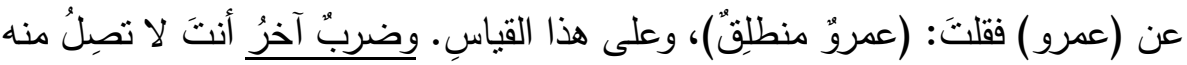

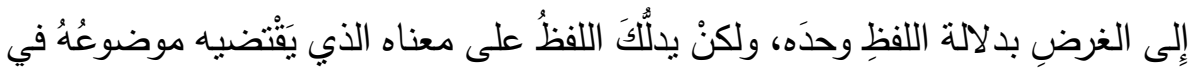

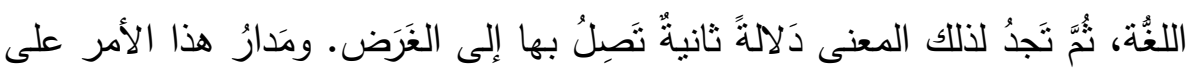

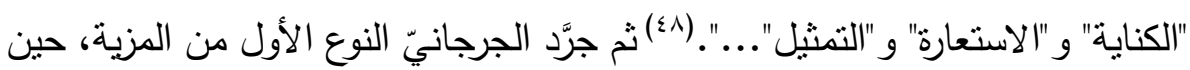
قال: "وإنما تكون المزيَّة ويجب الفضل إذا احتمل في ظاهر الحال غير الوجه الذي

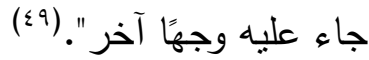
أما علماء الأصول فجعلوا تحت ما يطلق عليه الغربيون الأفعال المباشرة

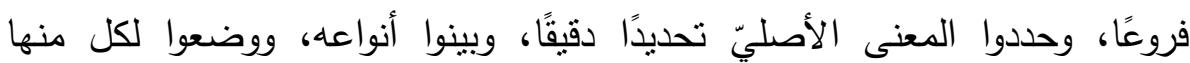
(ٓ؟) انظر: دراسة المعنى عند الأصوليين، طاهر حمودة، الدار الجامعية للطباعة والنشر والتوزيع، الإسكندرية، $.10 V-119961914$

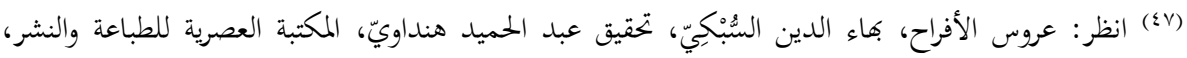

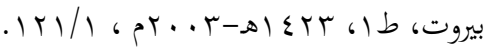

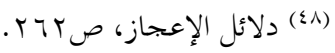

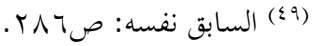


مصطلحًا يميزه عن غيره؛ إذ أطلقوا مصطلح "المحكم" على ما يدل بألفاظه على

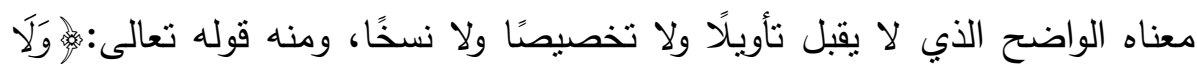

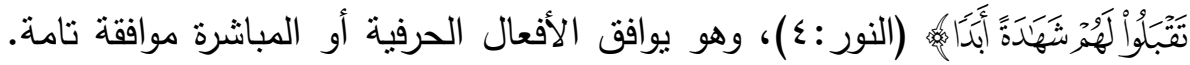

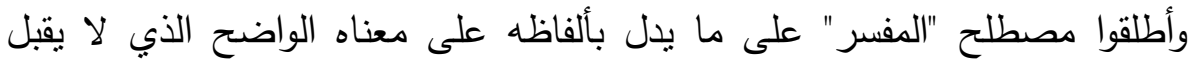

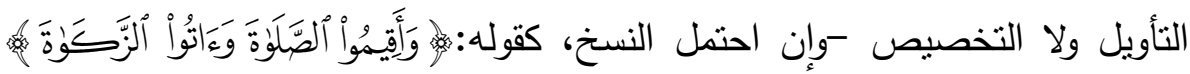
(البقرة: ؟)، فقد فسرت السنة مجمل كل منهما، لكن ظل له معناه الأصلي، ولا فرق

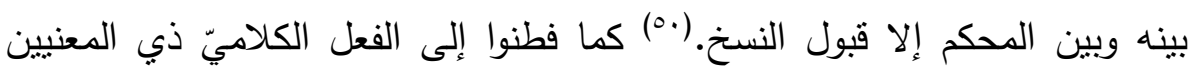
المرادين، حين أطلقوا مصطلح "النص" على المقصود الأصليّ من سوق الكلام، ومصطلح "الظاهر" على المقصود تبعًا، ثم عادوا فأطلقوا مصطلح "دلالة العبارة" على المقصود أصالة أو تبعًا.(1) وقسّم الثاطبيّ الدلالة إلى: أصلية- تشترك فيها جميع الألسنة، وإليها تنتهي مقاصد المتكلمين، ولا تختص بأمة دون أخرى، وتابعة- يختص بها لسان العرب،

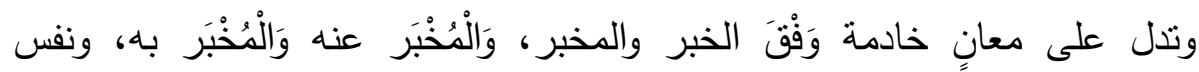

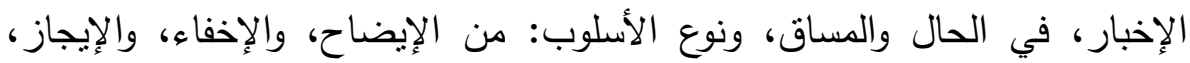

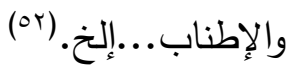
وتعرّف الأفعال الكلامية المباشرة بأنها "ما يتلفظ به المتكلم في خطابه، وهو

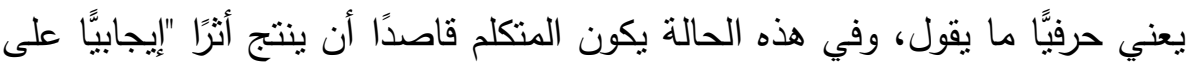

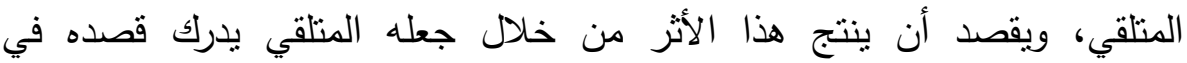
الإنجاز".(or) أما الأفعال الكلامية غير المباشرة فهي "إستراتيجية لغوية تلميحية يعبر بها المتكلم عن القصد بما يغاير معنى الخطاب الحرفيّ؛ لينجز بها أكثر مما يقوله؛

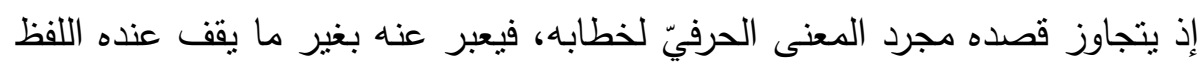

$$
\begin{aligned}
& \text { (0.(0) انظر تفصيل ذلك في: دراسة المعنى عند الأصوليين، صج ب ا وما بعدها. }
\end{aligned}
$$

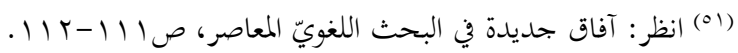

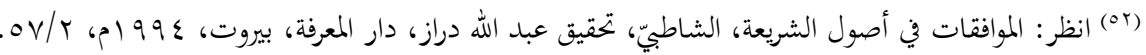

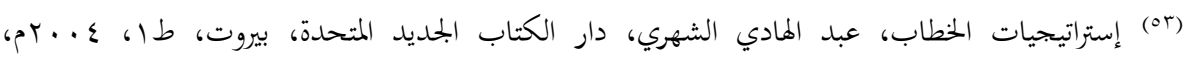


مستثمرًا في ذللك عنصر السياق".(\&) كما عرفت بأنها "الأفعال ذات المعاني الضمنية

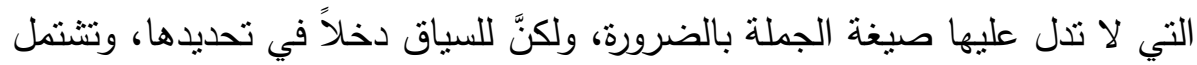
على معانٍ عرفية وحوارية". (00) ويعتمد استعمال الأفعال غير المباشرة على علاقتين، وهما- علاقة

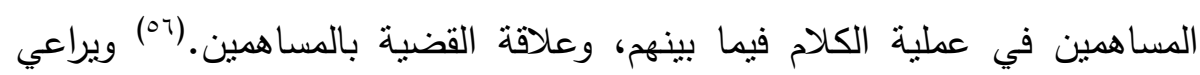

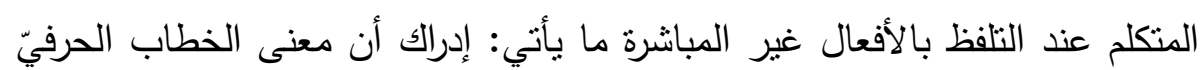
لن يناسب السياق، أو يعبر عن المراد، فيختار التعبير وفق أسلوب التلفظ بالأفعال

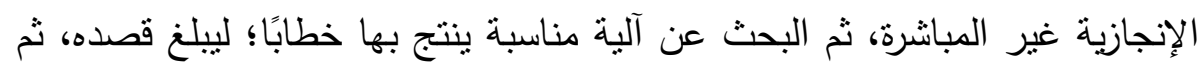

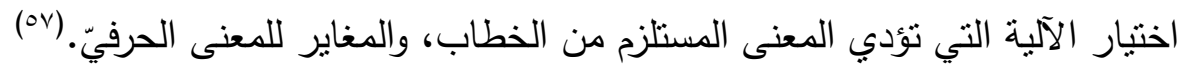
وتتعدد محددات الفعل الكلامي المباشر وغير المباشر ، وأههها:

1- السياق: نبه الأصوليون إلى أهمية المقام الذي ينبغي أن يفهم المقال من خلالها،

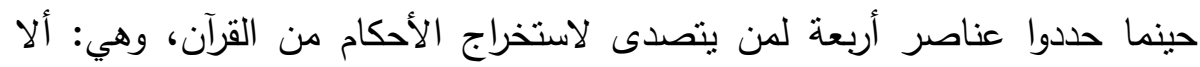

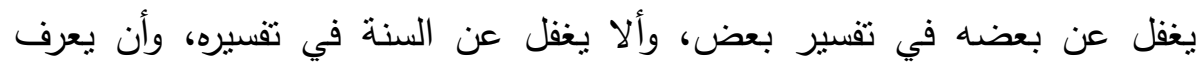

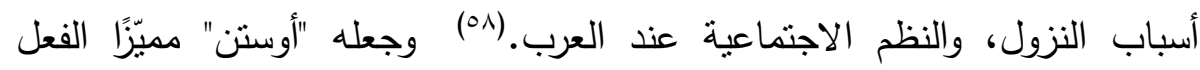

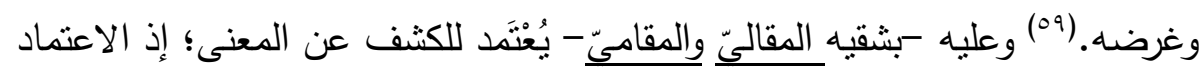
على المستوى المقاليّ كوحده- لا يعطي إلا المعنى الحرفيّ أو معنى ظاهر النص

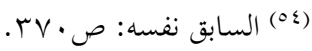

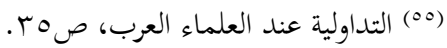
(7) انظر: تداوليات الخطاب ولسانيات السكاكيّ، أحمد الإدريسيّ، رسالة دكتوراة، جامعة القاهرة، كلية الآداب، .

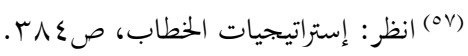

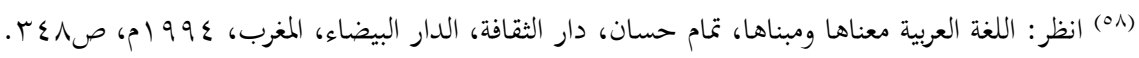

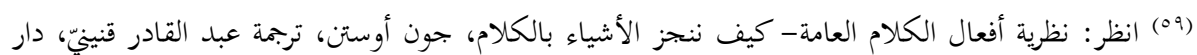

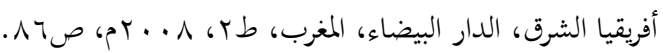
rV. 
الذي ينعزل عن كل ما يحيط بالنص من ظروف أداء المقال، والقرائن الحالية

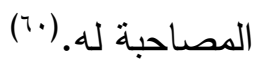

والاليل على ذللك أن عدم العلم بالمعنى المقاميّ، والاكتفاء بالمعنى القضويّ- قد أدى إلى وقوع المسلمين في اللبس في فهم المراد من "الظلم" في

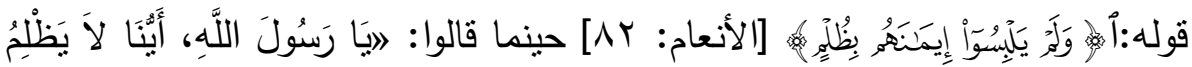

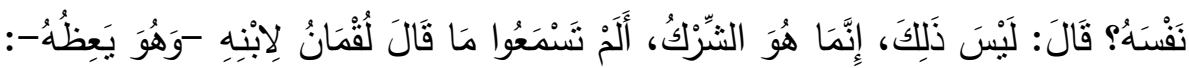

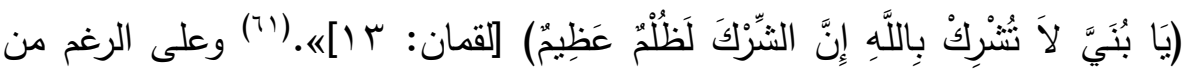
تعدد دوال التعبير عن الفعل المباشر أو غير المباشر، ومنها: الوحدات المعجمبة

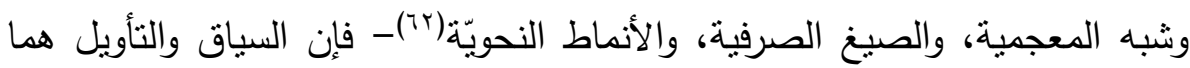

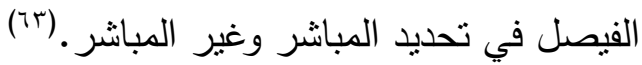
r- العرف اللُّكَويّ الاستعماليّ ومقصد المتكلم: هما أساسا النظرية المقامية العربية

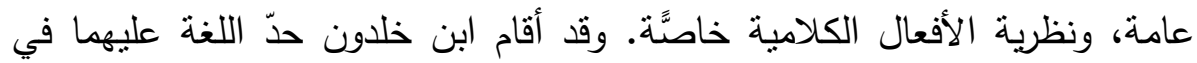

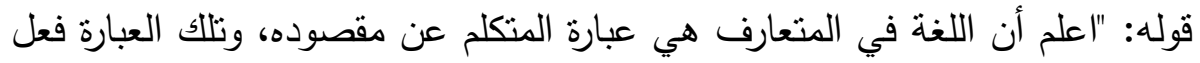

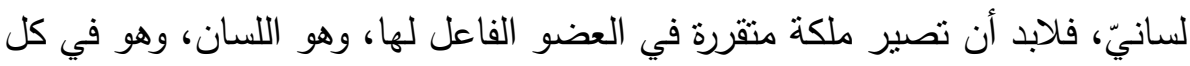

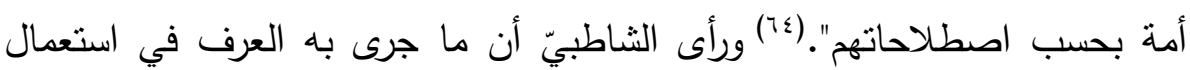

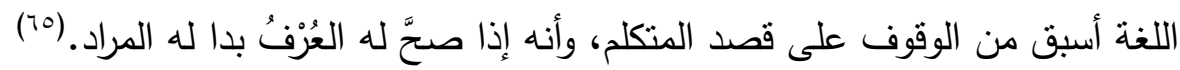
ويقصد بعرفية الاستعمال استعمال اللغة وفق ما تعارف إليه أبناؤها في مفرداتها وتراكيبها ودلالاتها، وما تقتضيه مقامات الكلام وأعراف الناس وأحكام

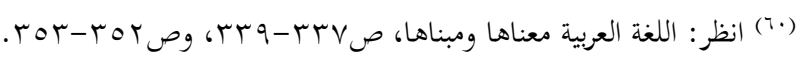

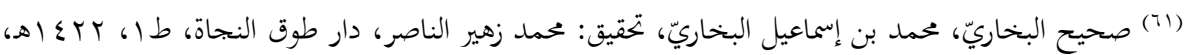
$.17 \pi / \varepsilon$

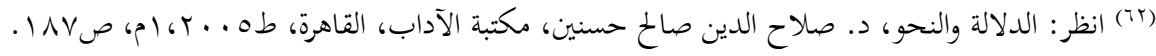

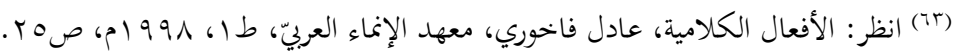

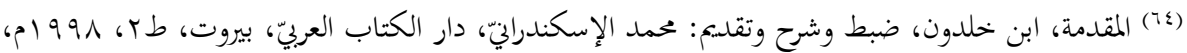

$$
\text { (70) انظر : الموافقات في أصول الشريعة، rVo/r. }
$$


الشرع. ولقد أكد "سيرل" دور العرف في تحقيق الفعل غير المباشر، ووصوله إلى المتلقي بالصورة المطلوبة.(זי) إن قولنا: "هل يمكنك أن تقتح الباب؟" أو "هل يمكنني

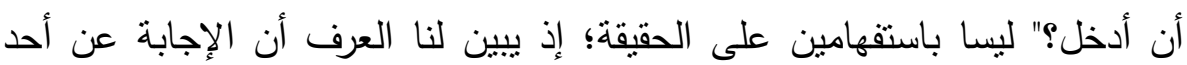
المنطوقين ليست ب"نعم" ولا بـ"لا"، وأن الصيغة الدالة على الإمكان (بمكنني) لا نسأل

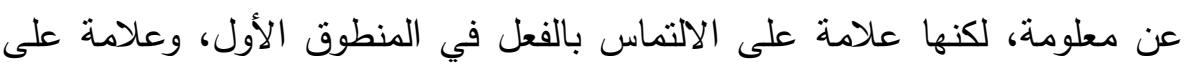

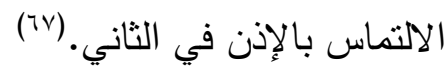
أما مقصد المتكلم فقد اهتم به الأصوليون، وفضلوه على الصبغة إذا طرأ

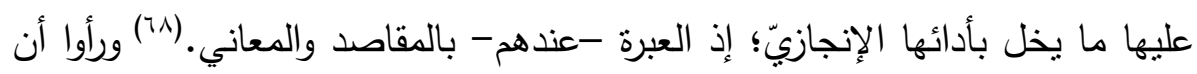

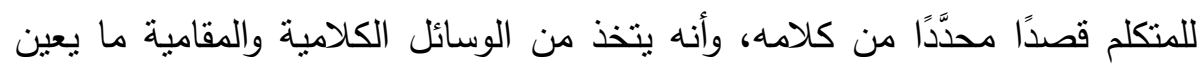
المخاطب على إدراك ما يريد، وبراعي تفاوت المخاطبين في فهم مقاصده.(79) وحذّر "ابن القيم" من مغبة إهمال قصد المتكلم، فقال: "فاياك أن تهمل قصد المتكلم ونيته

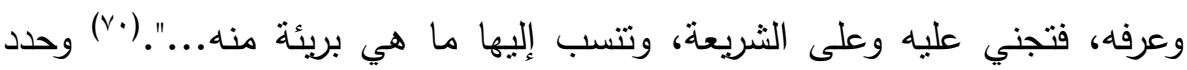

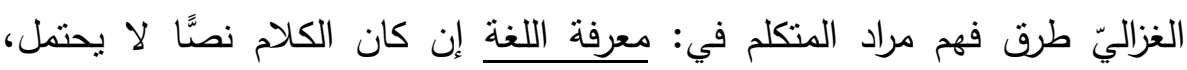

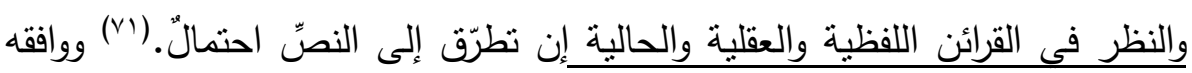

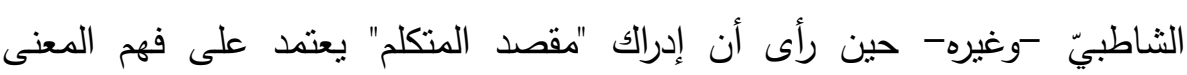
الأصليّ للألفاظ، والمعنى السياقيّ الاستعماليّ. (vr)

(17) انظر: بلاغة الخطاب وعلم النص، د. صلاح فضل، الشركة المصرية العالمية لونحمان، القاهرة، طاه

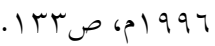

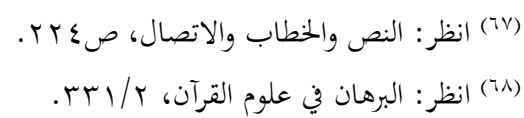

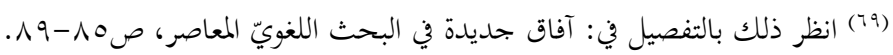

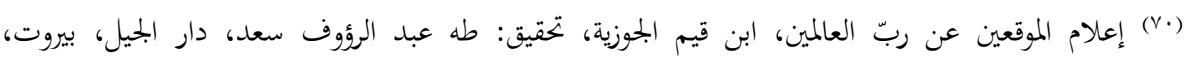
$.0 \varepsilon-0 \% / r$ (p) $9 V T$ (VI) المستصفى من علم الأصول، الغزاليّ، تحقيق محمد عبد السلام عبد الشافي، دار الكتب العلمية، طاه، $.117-110 / 1$ r 1994

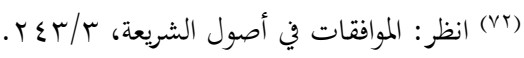
TVY 
r- الغرض الإنجازيّي: يميز بين الأفعال المباشرة وغير المباشرة؛ إذ هو في المباشرة:

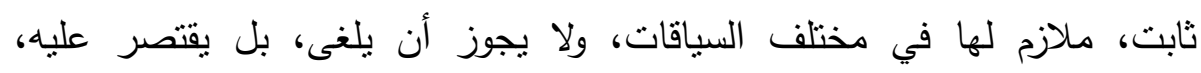

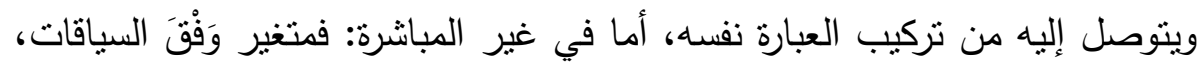

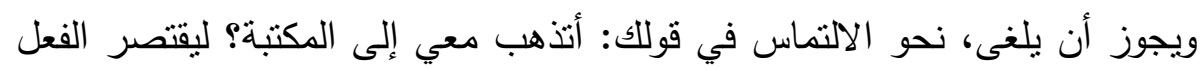

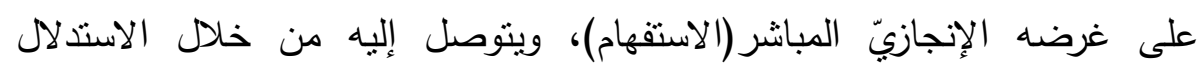

العقليّ. ع ع (v)

ع- القوة الإنجازيّة: يعد الإنجاز في الأفعال المباشرة أقوى منه في الأفعال غير

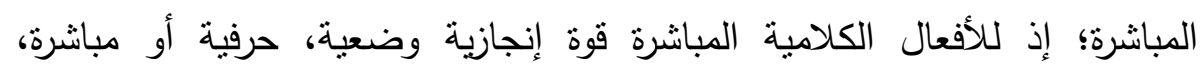
وصريحة لا تحتمل التأويل، نحو: قوة الأمر في وجوب الفعل، وقوة النهي في نرك إنك

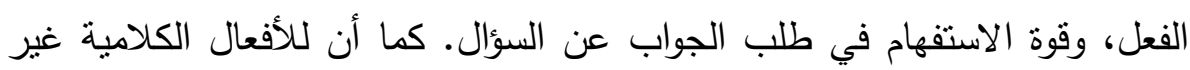

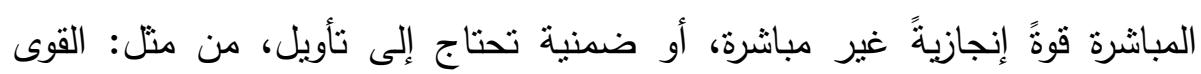

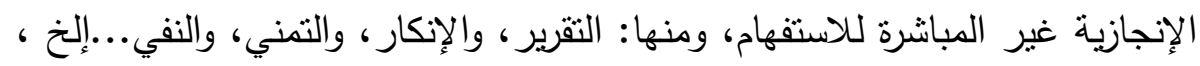

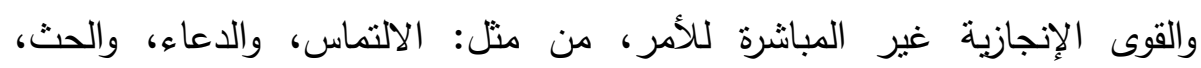
والتحضيض، والتهديد...إلخ.

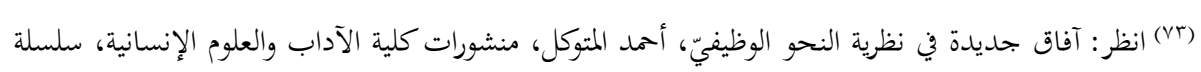

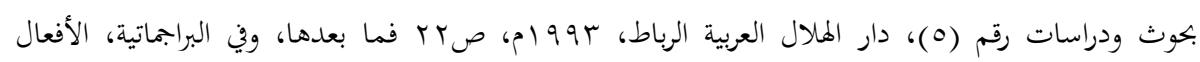

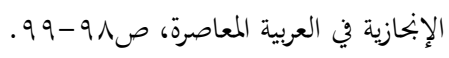




\section{المبحث الثاني: الاستفهام والقوة الإنجازية}

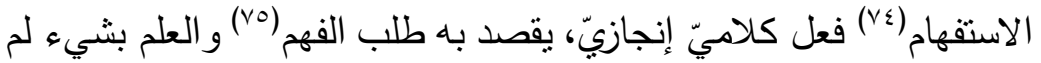

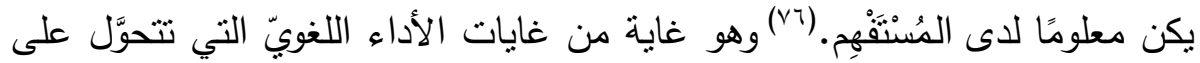

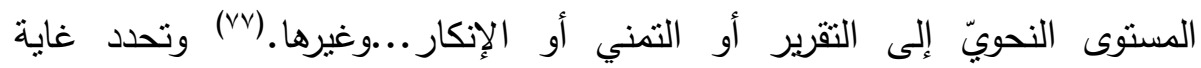
الاستقهام كونه تعاملًا أو إفصاحًا، فإذا كانت غايته طلب فهم ما يجهله السائل فهو التها تعامل، وإذا كانت غايته التقرير أو الإنكار - أو غيرهما- فهو إفصاح.

(V乏) وسماه آخرون "الاستخبار"؛ أي: طلب الخبر أو استدعاء الجواب. انظر: جامع البيان، الطبريّ، تحقيق أحمد

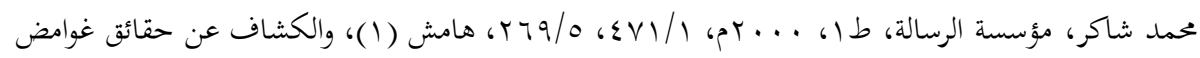

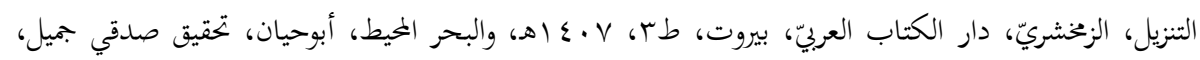

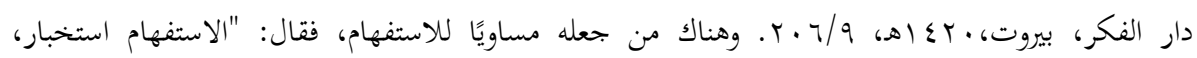

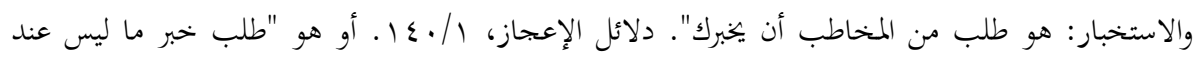

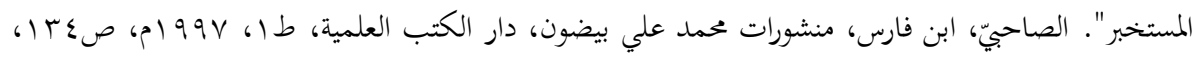

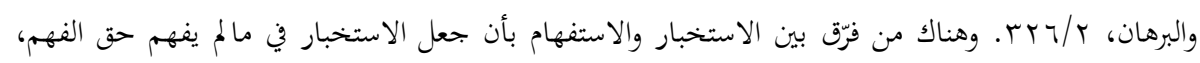

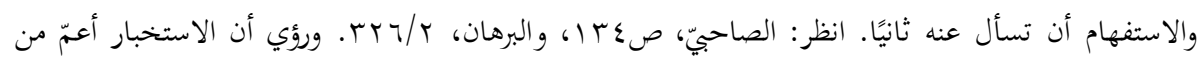

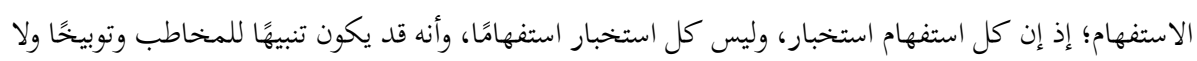

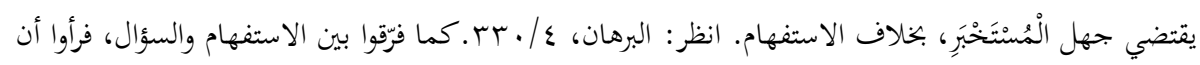

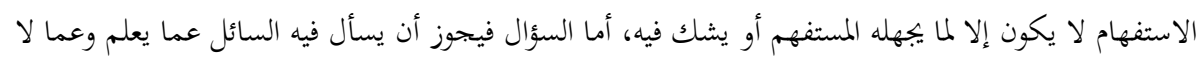

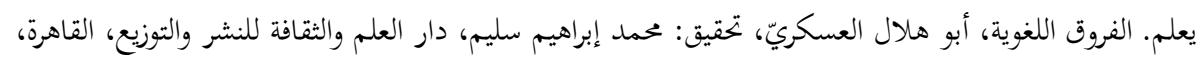

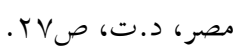

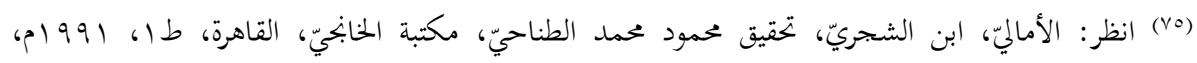

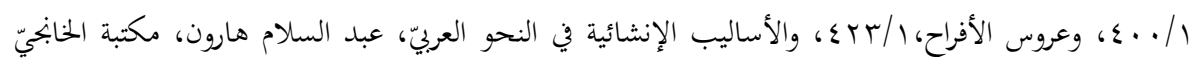

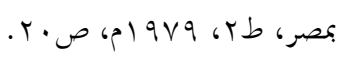

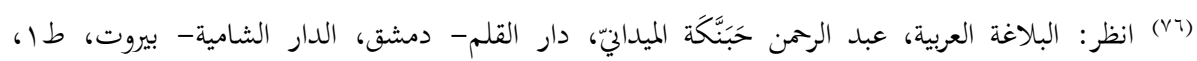

$$
\text { .r०N/1 r (999 }
$$

غايات الأداء اللغويّ: جزء من أجزاء المقام، وقريب منها "مقتضى الحال" عند البلاغيين. والتعامل والإفصاح غايتان من أكبر غاياته، ويقصد بـ"التعامل": استخدام اللغة بقصد التأثير في البيئة الطبيعية أو الاجتماعية المحيطة بالفرد، ويقصد بـ"الإفصاح" استعمال اللغة بقصد التعبير عن موقف نفسيّ من دون إرادة التأثير في البيئة. انظر

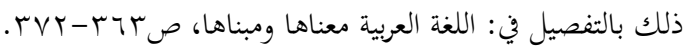


ويرتبط الاستفهام بالأفعال الكلامية Speech Acts؛ إذ هو معنى فرعيّ

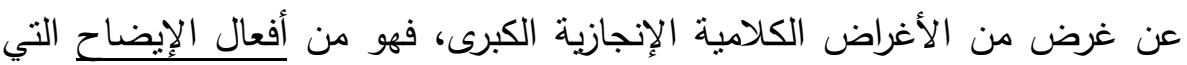
تستخدم لتوضيح وجهة النظر، أو بيان الرأي وذكر الحجة عند "أوستن".(ㅅ) أبي: يسنوضح فيها السائل من المخاطب عن شيء غامض يجهله؛ من أجل إزالة اللبس. وهو من أفعال التوجيه؛ التي يوجه فيها المتكلمُ المخاطبَ إلى فعل شيء منه ما، أو

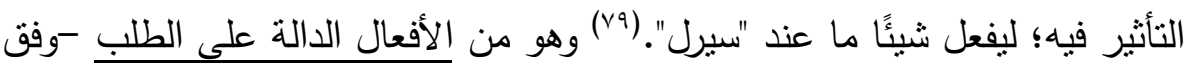
النزاث العربيّ-؛؛ إذ يطلب فيها المتكلم من المخاطب الجواب عن سؤال يجهله.

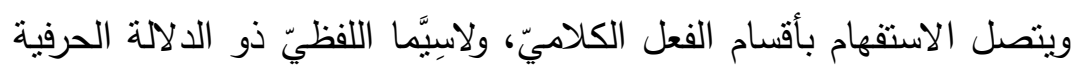
والمتضمن في القول عند أوستن، أو القضويّ والإنجازيّ عند سيرل الذي يقابله مقصد

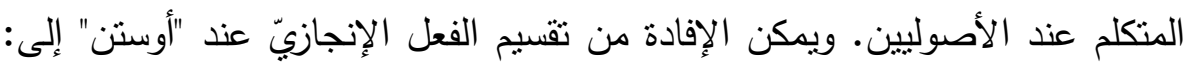

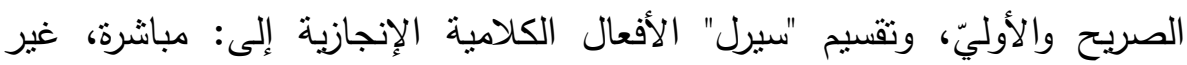

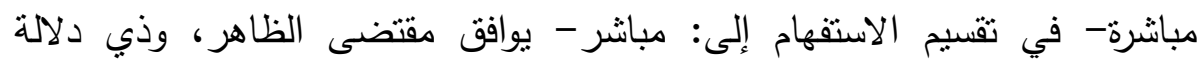
وضعية مباشرة أو حرفية، وغير مباشر - يخرج عن مقتضى الظاهر، وذي دلالة ضمنية.

وذكر السكاكيّ أن الطلب بأنواعه -ومنه الاستفهام- قد ينتقل من معناه

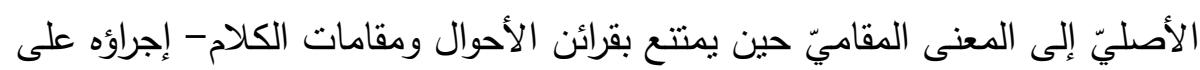

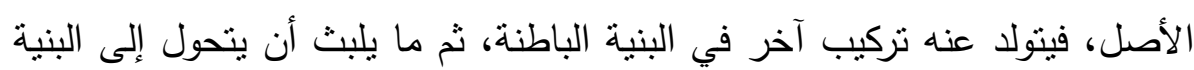

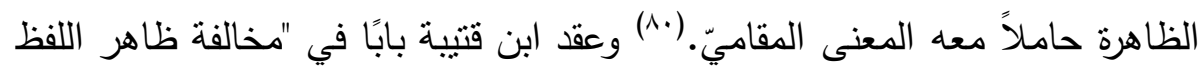

Austin. J. L. (1962), P. 160f.

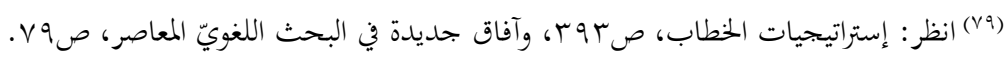

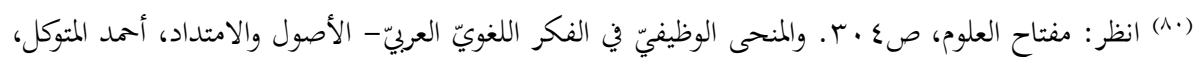

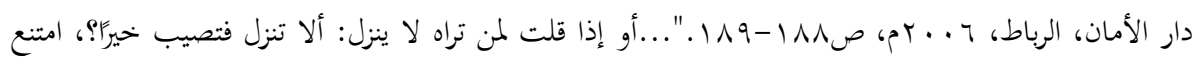

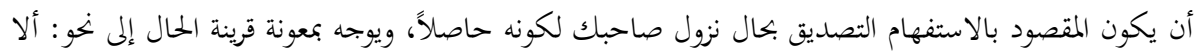

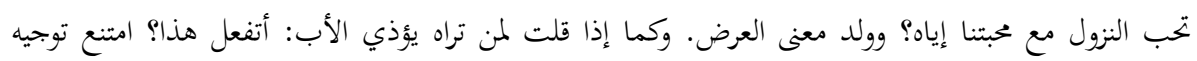

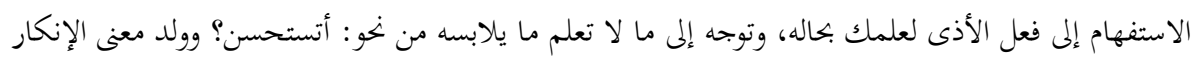

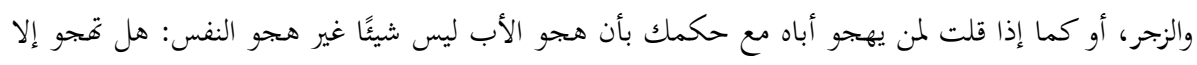


معناه"، واستعرض بعض الأوجه التي يخالف فيها ظاهر اللفظ معناه، ومنها أن يأتي

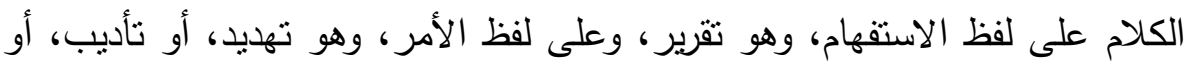

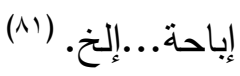

\section{الاستفهام المباشر وغير المباشر : مفهومهما، وأهم محدداتهما}

يُعرَّفُ الباحث الاستقهام المباشر بأنه "فعل كلاهيّ إنجازيّ مباشر، يتوافق

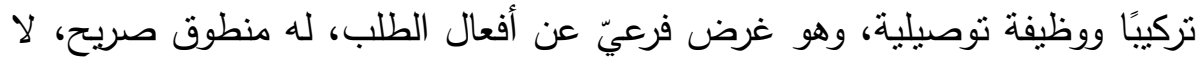
يحتمل التأويل، ويقصد به إنجاز المعنى الحرفيّ الذي يلازمه في مختلف السياقات؛

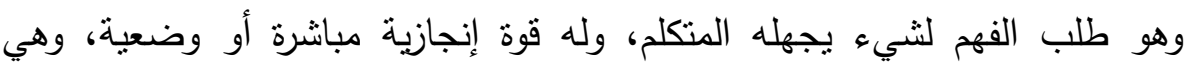
الجواب عن السؤال، بأداة تمثل الدليل الإنجازيّ للاستفهام، ويطلب بها تصور أنها

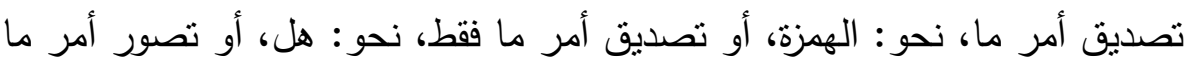
فقط، نحو : من، وأين، وكيف، وأَنَّى...وغيرها، أو من دون أداة؛ إذ يحل التَّلوين

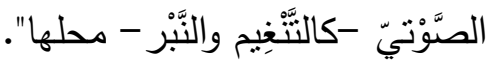
وللاستقهام المباشر محددات وضوابط يجب توافرها، من أهمها- عنصر الزمان؛ أي أن يكون المستفهم عنه غير حاصل وقت الطلب-في اعتقاد المتكلّم.(Ar)

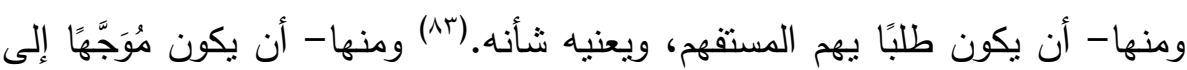

نفسك؟ أو غير نفسك؟ امتنع إجراء الاستفهام على ظاهره لاستدعائه أن يكون الهجو احتمل عندك توجهًا إلى

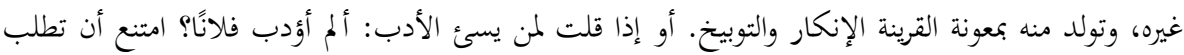
العلم بتأديبك فلانًا وهو حاصل، وتولد منه معنى الوعيد والزجر . أو كما إذا قلت: لمن بعثت إلى مهمة وأنت تراه

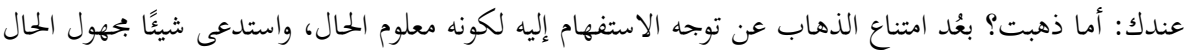

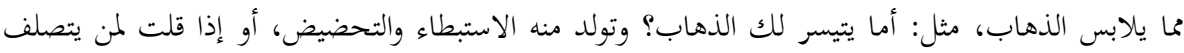

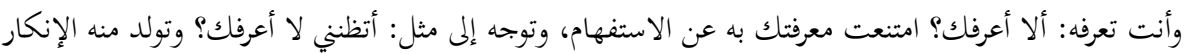
والتعجب والتعجيب، أو كما إذا قلت لمن جاءك أجئتن؟ امتنع المحئ عن الاستفهام، وولد بمعونة القرينة التقرير".

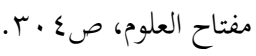

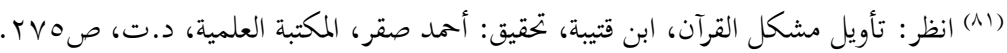

$$
\text { (Ar) }
$$

(Ar) 
المخاطب؛ لأنه إن احتمل توجهه إلى غيره امتتع إجراؤه على ظاهره(^)، ومنهاعنصر الإمكان؛ إذ بإمكان المسؤول الإجابة عن السؤال الموجه إليه؛ لمعرفته

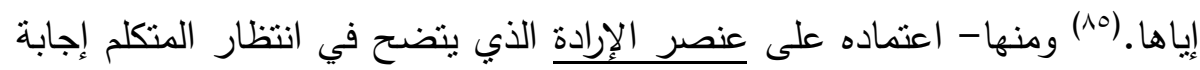

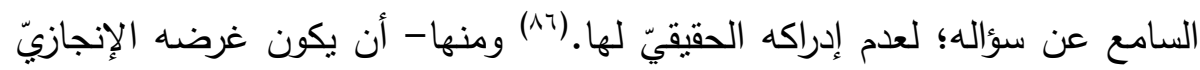

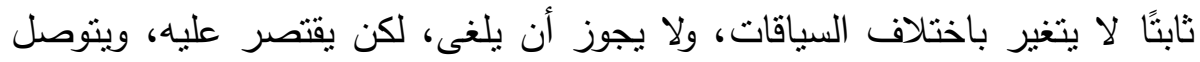

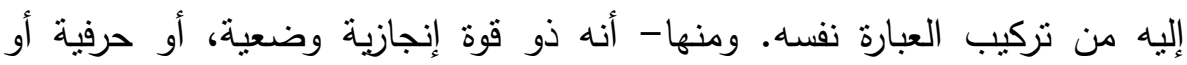

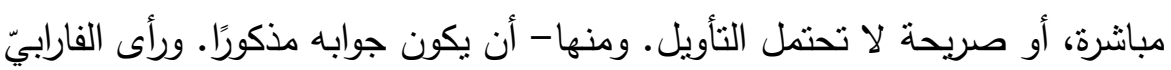

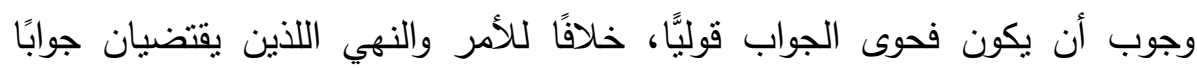
فعليًّا. (^v)

ويعرّّف الباحث الاستفهام غير المباشر بأنه "فعل كلاميّ إنجازيّ غير مباشر، لا يتوافق تركيبًا ووظيفة توصيلية؛ إذ تدل هيئته التركيبية على معنى لا لانيل

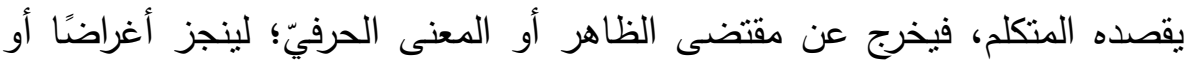
معاني-عند البلاغيين-، أو"وظائف تواصلية إبلاغية" بتعبير الوظيفيين، أو "أفعالا

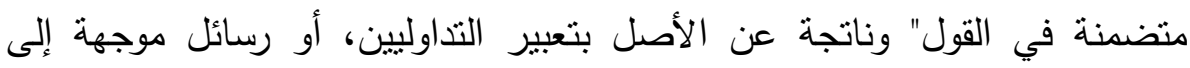

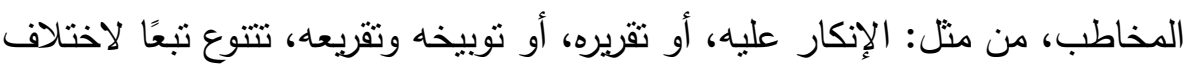

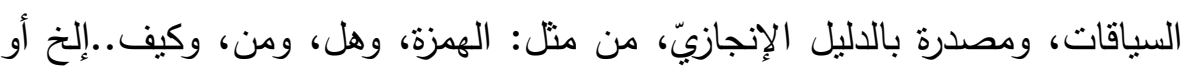

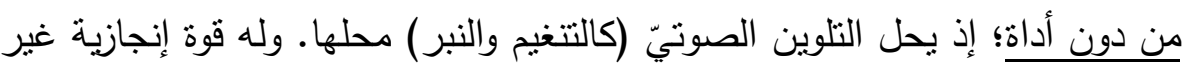
مباشرة تتفاوت شدة وضعفًا، وتتضمن معنى ثانويًّا". وللاستفهام غير المباشر محددات وضوابط يجب توافرها، منها - السياق. ومنها- قصد المتكلم من الخطاب؛ إذ لا ينتظر جوابًا عن سؤاله، ومنها- قدرة المُخَاطَب على فهم قصد السائل. ومنها- ألا يكون الاستقهام متعلقًا بالمستقبل، وألا

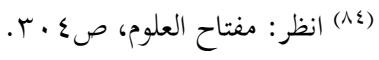

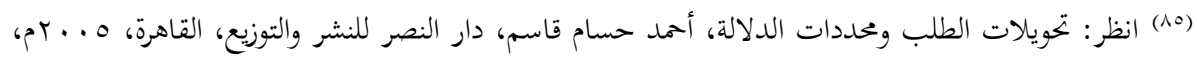


تكون إجابة السؤال في إمكان المسؤولـولو من وجهة نظر السائل على الأقل.(^)

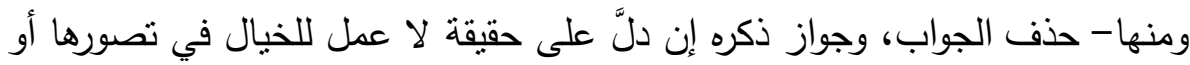

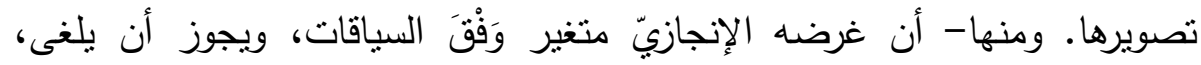

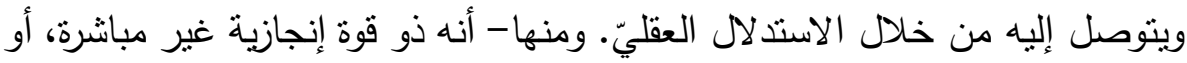

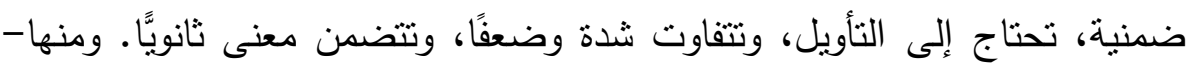

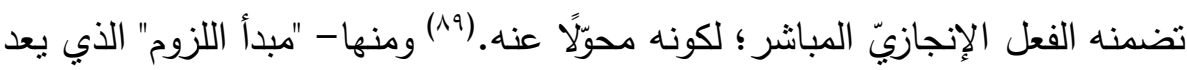

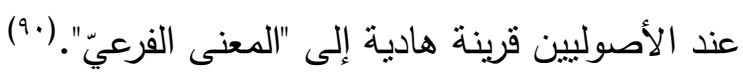

\section{القوة الإنجازيـية}

القوة الإنجازية illocutionary force جزءٌ من البنية الدلالية للفعل الكلاميّ الإنجازيّ"(9)، وتعرف بأنها "الثدة أو الضعف اللذان يعبر بهما عن غرض إنجازيّ من النهي

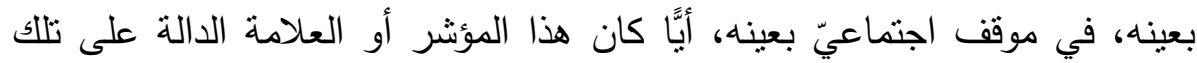
القوة، وإذا كان لكل من الثدة والضعف درجات متفاوتة، وصفت القوة الإنجازية بأنها

نسبية". (9)

وقد التقت أبو هلال العسكريّ إلى تفاوت درجة القوة في الفعل الإنجازيّ-

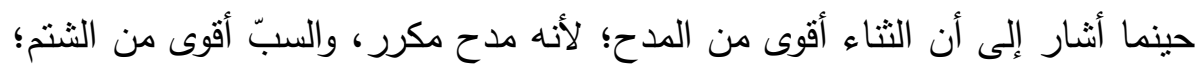

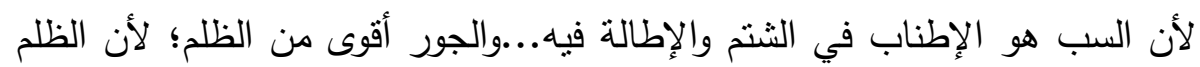

(1^) انظر: تحويلات الطلب ومحددات الدلالة، صو ا 1، وفي البراجماتية، الأفعال الإنجازية في العربية المعاصرة،

Helbig. G. (1990), S.200.

(·•) ينصرف الذهن عن طريق اللزوم إلى معالٍ سياقية للاستفهام عندما يجصل له اقتناع بأن المعنى الحقيقيّ غير

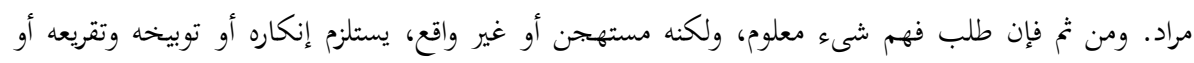

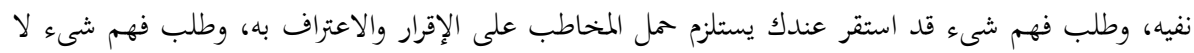
إمكان لوقوعه يستلزم التمني، وطلب فهم شىء لا قدرة عليه يستلزم التعجيز .

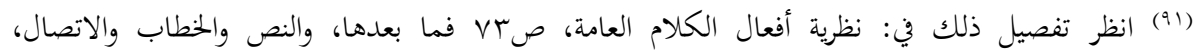


نقصان الحق، والجور: العدول عن الحق، والفزع أقوى من الخوف؛ لأنه خوف

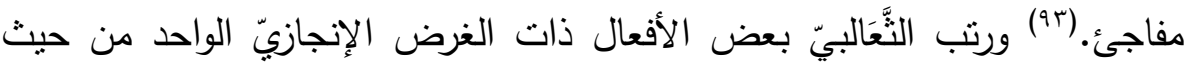

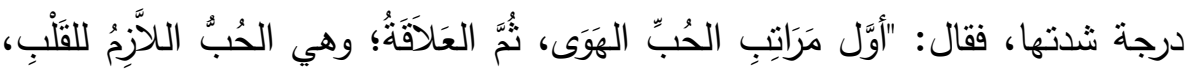

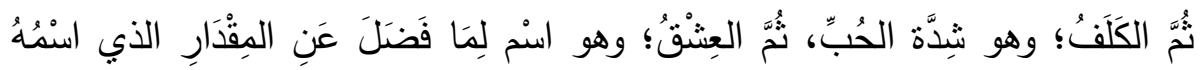

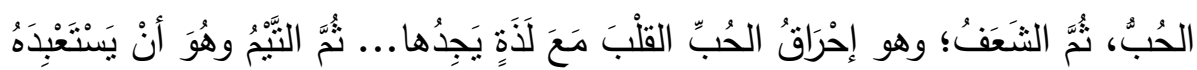

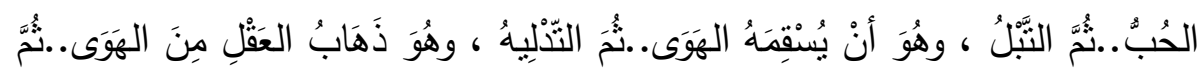

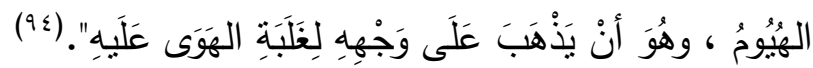

\section{الفرق بين القوة والغرض}

خلط "أوستن" بين مفهومي القوة والغرض؛ إذ استعمل مصطلح القوة (Force)

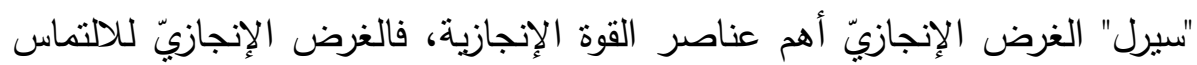

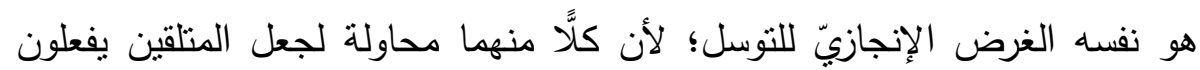

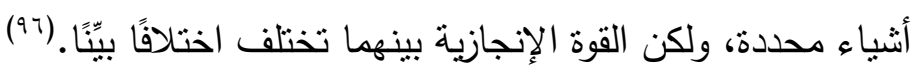
لقد عَدَّ "سيرل" القوة الإنجازية بعدًا من أبعاد التمييز بين الأفعال الإنجازية

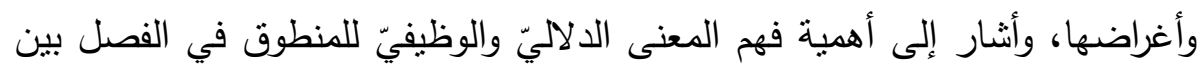
درجات قوة الفعل الإنجازيّ؛ إذ المعنى محدِّد من محددات القوة الإنجازية بمعاونة السياق وعناصره. في حين رأى محمد العبد أن القوة الإنجازية بعد من أبعاد التمبيز بين الأغراض الإنجازية الفرعية لغرض إنجازيّ أكبر واحد، فالاقتراح والإصرار فعلان

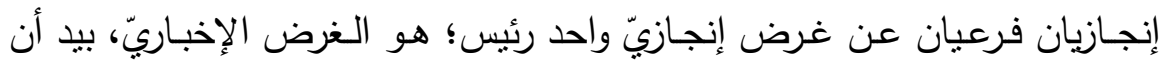

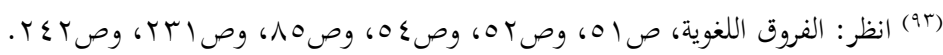

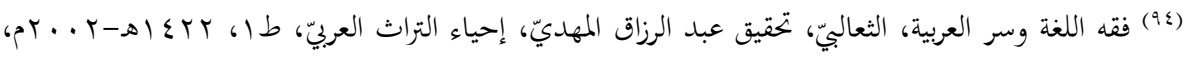

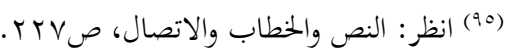

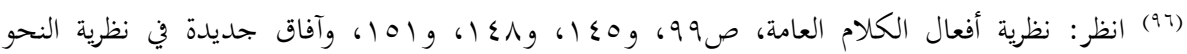
الوظيفيّ، صז r-rr. 
درجات القوة بينهما مختلفة. (9v)

إن قوة الفعل الإنجازيّ جزء مكمل لمعناه، وهذا بعني أن المعنى أوسع من

القوة؛ لأنه يضم القوة والمحتوى القضويّ في آن معًا. واللافت أن استعمالات اللغة غير محدودة من جهة القوة الإنجازية، بل من جهة الغرض الإنجازيّ الذي حصره "سيرل" في خمسة أغراض. (9^) وخلاصة القول إن القوة والغرض عنصران مكملن للمعنى، وإن القوة درجة والغرض وظيفة، مثل: (أفعال التوجيه) التي تتعدد أغراضها الفرعية، كالأمر والالتماس والعرض والتحضيض وغيرها. ولكل غرض فرعيّ درجات منفاوتة من القوة وَفْقَ سياقات الاتصال. ويعتمد تقسير كل من الغرض الإنجازيّ والقوة الإنجازية على الصيغة اللغوية للمنطوق، والسياق والمعنى.(99) وإذا كان "أوستن" قد رأى أن قوة المنطوق الإنجازية تحقيق لمقصد المتكلم تحقيقًا ناجحًا، فقد خالفه "سيرل" حين رأى أن القوة تفسير المستمع للمنطوق، وما يعدد إليه لا ما يقصده المتكلم؛ إذ لا يمكن أن يتأكد أحد المتلقين أو محللو الخطاب من مقصد المتكلم؛ لأنه لا يقبل الفحص، أما تفسير المتلقي فيتجلى في استجابته، وهذا ما يحدد ثقدم التفاعل اللغويّ أو نجاحه.(.') وحدد "أوستن" وسائل القوة الإنجازية للفعل في: الصيغة وما يعاضدها من أفعال مساعدة، نحو قولنا: "أَغْلِق البَابَ" التي تضاهي "آمرك"، و "أغلق الباب" إذا أردت تضاهي "آذن للك"، ونغمة الصوت أو التتغيم والتفخيم: وتختلف نغمة التحذير عن نغمة السؤال أو الاعتراض...إلخ، وأشباه الجمل (ظروف الزمان والمكان): ويقصد بها تكييف المنطوق، منل نكييف قوة "سوف أفعل" بإضافة "من المحتمل"، أو تكييف قوة النهي بالظرف، مثل: "لا تتس أبدًا"، وأدوات الربط بين الجمل: مثل "من

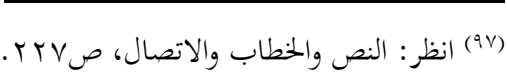

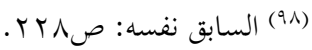

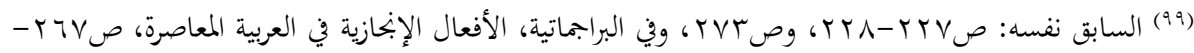


أجل ذلك التي تستخدم في قوة "استتنج"، و"على الرغم من ذلك" التي تستخدم في قوة

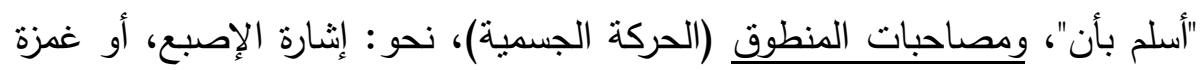

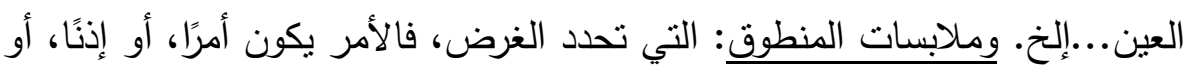

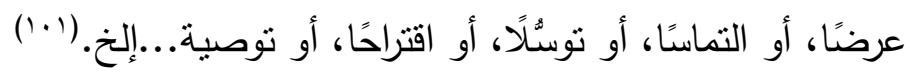

\section{Modifying illocutionary Force تعديل القوة الإنجازية}

للمتكلم أن يعدل منطوقه وفق مقصده في سياق معين عن طريق اختياره

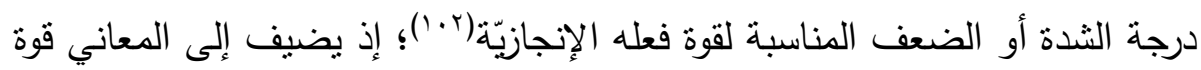
إنجازية ترسخ المعنى في ذهن المتلقي، كما يمكن أن يتعدد المتكلم عدم إيضاح مقدار فوة المنطوق الإنجازية، ويجعلها

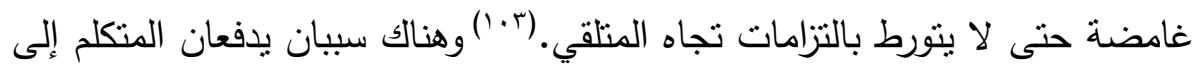
تعديل قوة الفعل الإنجازيّ، هما-نقل المعنى المرتبط بالمتكلم وتصرفاته إزاء القضية التي يعبر عنها، والتعبير عن معنى نأثيريّ affective meaning، أو عن سلوك

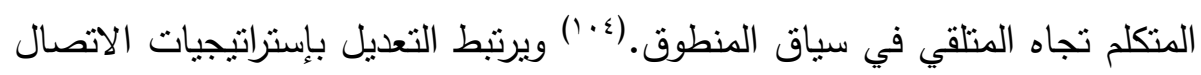
التي تتتوع من حالة إلى أخرى، وبغرض المتكلم الذي بحدد الطريقة التي بتكلم بها،

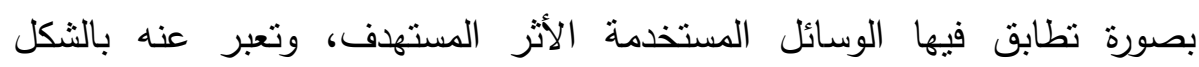
المطلوب؛ لإتمام الاتصال ووصول الرسالة. إستراتيجيات التعديل: لتعديل قوة الإنجاز إستراتيجيتان، هما- التقوية التي تهدف إلى الإلى

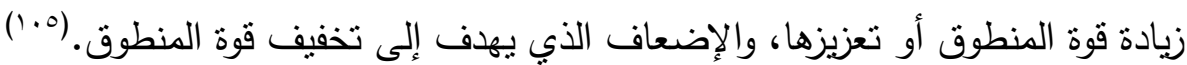

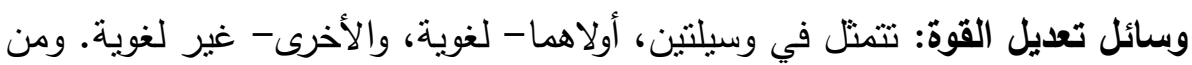

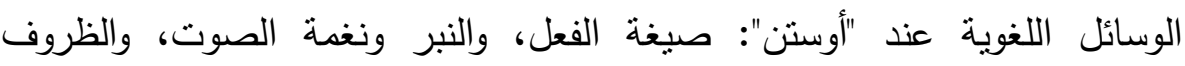

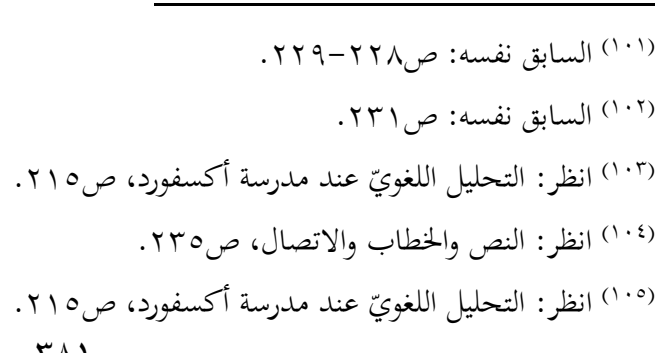

rN 
النحوية، وأدوات الربط بين العبارات(؟·') وعد "سيرل" نظام الجملة، والنبر Stress، والتتغيم Intonation، وعلامات الترقيم Punctuations، وصيغة الفعل mood، وما يسمى الأفعال الأدائية- من الوسائل المؤثرة في قوة المنطوق الإنجازية في اللغة

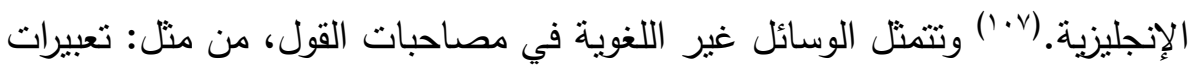
الوجه، وحركات الرأس واليد، وغمز العين...إلخ. وقد جمع ابن جني بين الوسائل

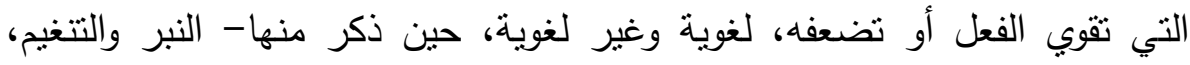

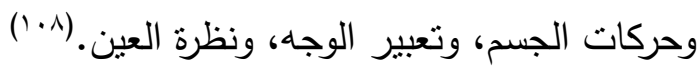

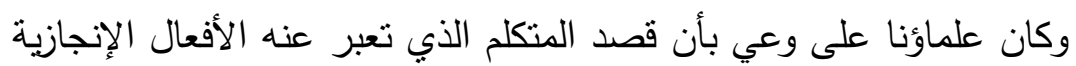

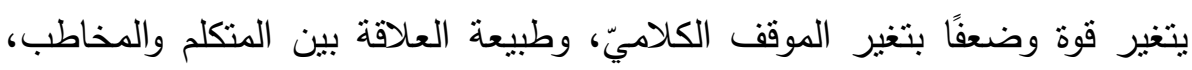

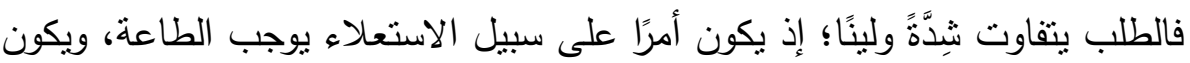

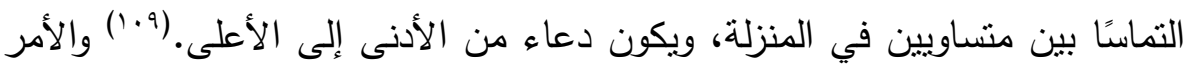

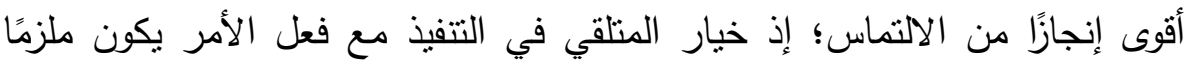
بصورة تفوق خياره في الالتماس. ويكون هذا الطلب قويَّا حين يستخدم المتكلم أفعال

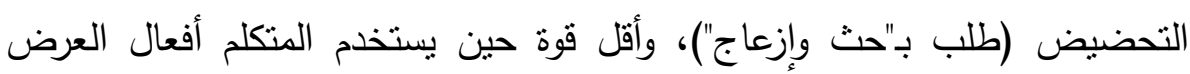

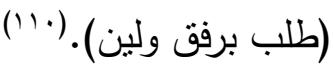
وسائل تقوية الفعل وإضعافه: تتعدد وسائل التقوية، ومنها- وسائل التشكيل الصوتيّ (نحو: النبر ، والتتغيم، وغيرهما)، والوسائل المعجمية، وتتشمل مقويات موجهة إلى:

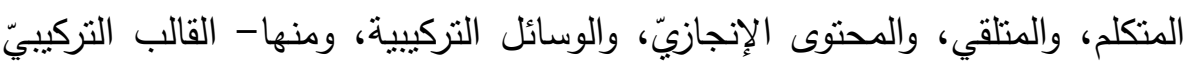

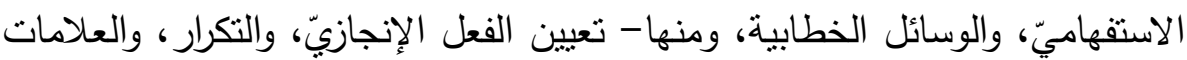

$$
\text { (7 ·. (1) انظر: نظرية أفعال الكلام العامة، صبو. }
$$

Searle. J. R. (1969), p. 39.

(^•(1) انظر: الخصائص، ابن جنيّ، تحقيق محمد علي النجار، الهيئة المصرية العامة للكتاب، مركز تحقيق التراث، P

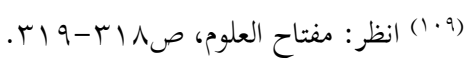
(.1) انظر: الأساليب الإنشائية في النحو العربي، صع ا وما بعدها، وآفاق جديدة في البحث اللغوي المعاصر، 
أو الأدوات الرابطة. وتعرف إستراتيجية الإضعاف من الوسائل ما عرفته إستراتيجية

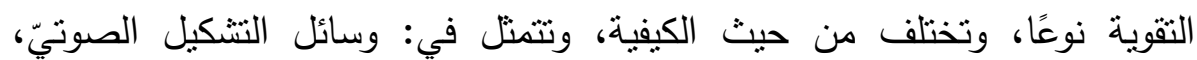
والوسائل المعجمية، وتتثمل مضعفات موجهة إلى المتكلم، والمنلقي، والمحتوى الإنجازيّ، والوسائل التركيبية، ومنها الإضعاف أو التلطيف بأنماط من الإنه الاستفهام الإنجازيّ غير المباشر ،والوسائل الخطابية.('l')

\section{الادراسة التطبقية}

\section{القوة الإنجازية للاستفهام في سور آل حم}

القوة الإنجازية للاستفهام نوعان، أحدهما- مباشرة أو وضعية؛ وهي الجواب

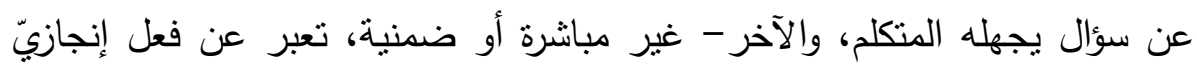

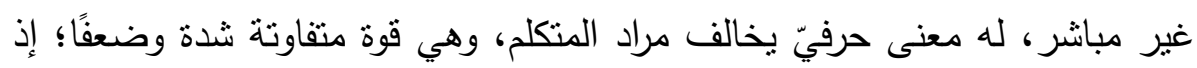
تعتمد على وسائل لتعديلها، وتتضمن معنى معنى ثانويًًا.

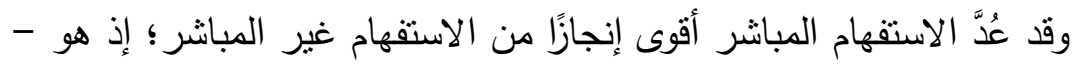

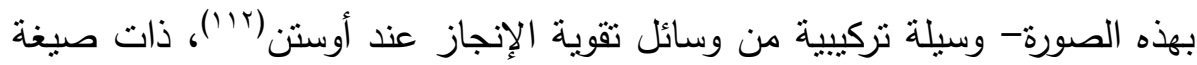
صريحة ومحددة، وتعلن عن نفسها في كل سياق تقال فيه، ولا تحتاج إلى التأويل،

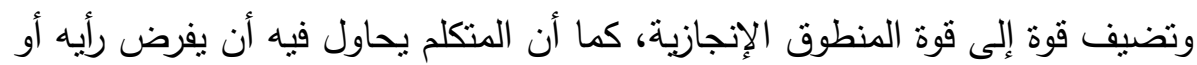
رغبته على المتلقي، وذلك بالجواب عن سؤال يجهله. خلافًا للاستفهام غير المباشر

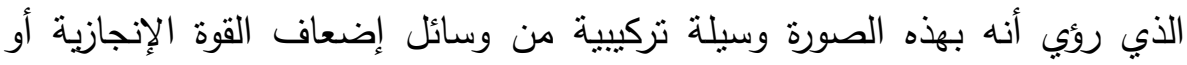

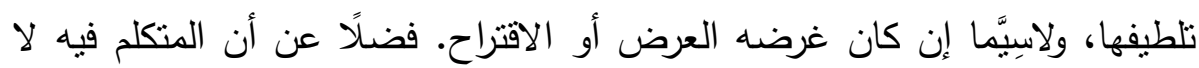

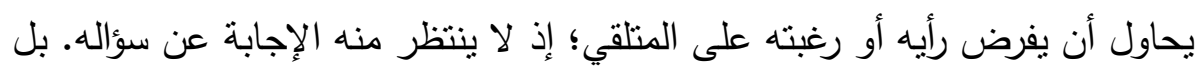

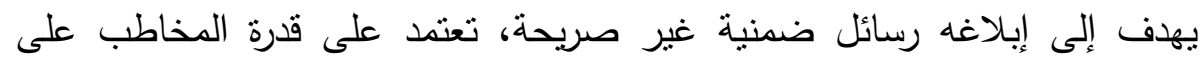
التأويل، وما تطرق إليه التأويل -في المعاني المتضدنة- لا ينبغي عليه التعويل.

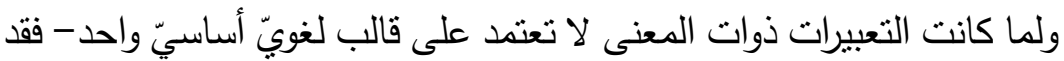

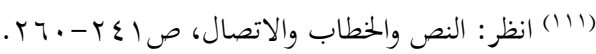

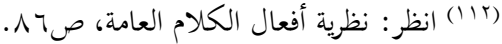


تمت صيغ التركيب الاستفهاميّ -في سور آل حم- في أكثر من قالب لغويّ؛ إذ استفهم بالدليل الإنجازيّ عن الاسم أو الجملة الاسمية، وكذلك عن الفعل أو الجملة الفعلية. أولا- الاستفهام المباشر في سور آل حم الإن ورد في سور آل حم في موضعين فقط، في قوله:

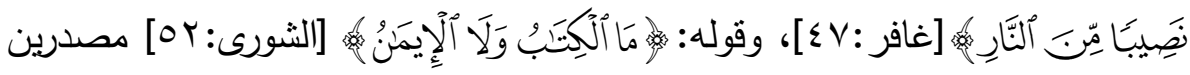
بالدليلين الإنجازيّين "هل" للتصديق في الموضع الأول، و "ما" للتصور في الموضع الإينع

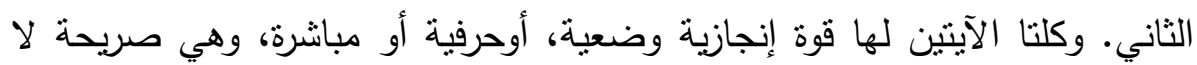

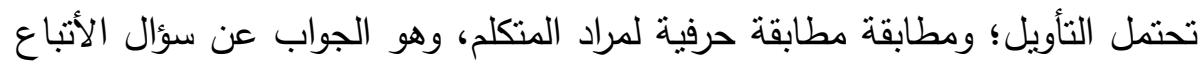
كبراءهم أن يتحملوا عنهم نصيبًا من العذاب في الآية الأولى، والجواب عن ماهية القرآن وحقيقة الإيمان في الثانية.

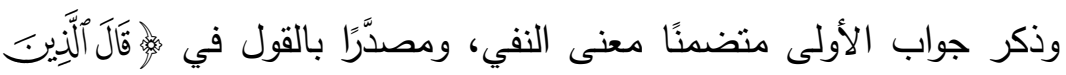

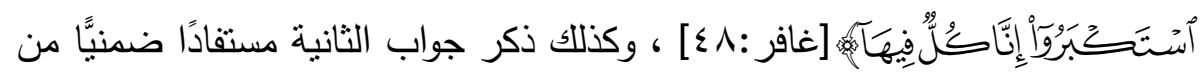

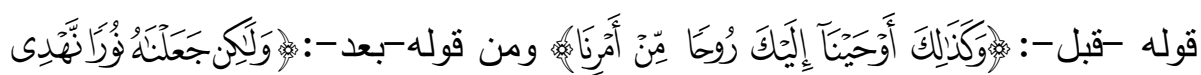
- برِ

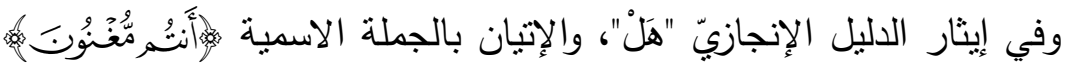

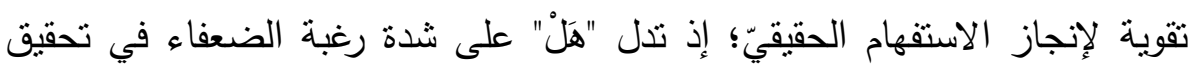

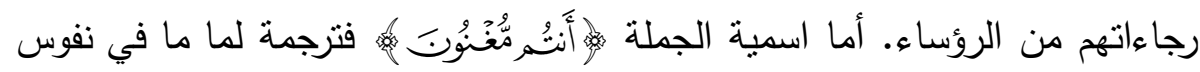

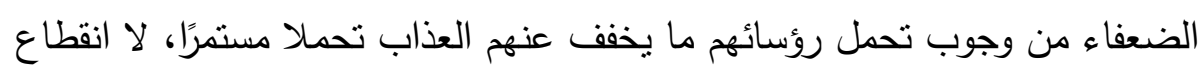

\section{ثانيًا- الاستفهام غير المباشر}

اختُصَّ النَّظُْ القرآنيّ في سور آل حم بعدد وافر من شواهد الاستفهام غير

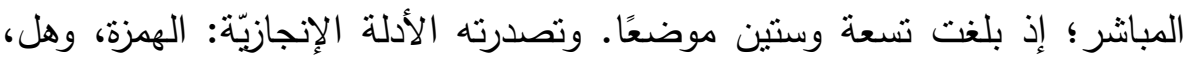

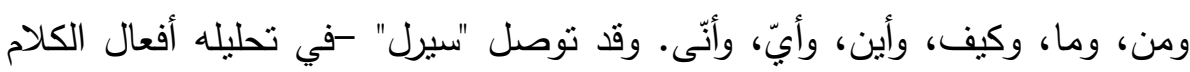
غير المباشرة- إلى أن المنطوق الواحد يمنل قوتين إنجازيتين؛ إذ يؤدي فعل إنجازيّ وتي توني 
أداء غير مباشر، عن طريق أداء فعل آخر. (r) ولقد وجدتتي -باستقراء آراء المفسربن والبلاغيين واللغوبين - أمام عدد كبير من الأغراض والدلالات المجازية للاستفهام غير المباشر -بلغت أكثر من خمسين-، وهي: الإنكار، والتوبيخ، والتقريع، والتهكم، والتهديد، والتكذيب، والتقرير، والتكبر، والافتخار ، والإفحام، والوعيد، والتخويف، والإلزام بالحجة، والتنبيه، والتجهيل، والتشنيع، والاستبعاد، والنصح، والتبصير والإرشاد، والنفي، والتعجيز، والاستحالة، والتتديم، والاغترار بالقوة، والاعتداد بالنفس، والرجاء، والتهويل والتفظيع، والتوقيف، والتثيت، والتقنيط والتيئيس، والذم والتحقير، والتعجيب، والرمي بالغفلة والبلادة والسفه، والاستهزاء، والسخرية، والتسفيه، والتبكيت، والاستعطاف، والتمني، والتحسر والتتدم، والوعد، والحث، واستدراج المخاطب إلى الاعتراف ، ونسلية النبيّ، والعتاب. وقد رددت كثيرًا منها، لاعتبارات، منها- ما شاب بعضها من تعميم، أو عدم مناسبة للسباق، أو كونها معنى ثانويًّا، ومن ثم يحتاج إلى إعادة التوظيف. وقد توصلت من خلال استقراء آراء المفسرين والبلاغيين واللغوبين، واستقراء النصوص القرآنية- إلى حصر القوى الإنجازية للاستقهام غير المباشر في سبع قوى إنجازية -فقط-، هي- التقرير، والإنكار، والنفي، وإثارة النشاط الذهني من أجل أمرية "أَخْبِرْني"، والتمني، والتعجيب، والاستحالة.

والاستهام -بهذه الصورة- فعل كلاميّ إنجازيّ غير مباشر؛ إذ معناه الحرفيّ الاستفهام، وهو غير مراد، وتخالف قوته الإنجازية الحرفية قوته الإنجازية غير الحرفية التي هي مراد المتكلم، وهي قوى إنجازية غير مباشرة تحكمها ضوابط، من أهمها- السياق، والعرف اللغويّ، وقصد المتكلم، وصيخة الفعل، والتركيب النحويّ، وقدرة المخاطب على الاستدلال، ومصاحبات الكلام...إلخ. 1 - التقرير: قوة إنجازبة غير مباشرة، وأساسية؛ لإقرار المخاطب بما يريد المتكلم، تتضمن معنى ثانويًّا، وقد تصدر بالدليلين الإنجازبيّن "الهمزة" و "من"، وأتي المقرر به بعدهما، سواء أكان فعلًا أم اسمًا. 
ومن شواهد المقرر به الفعل المضـارع المنفيّ بـ"لم": ما جاء بالدليل

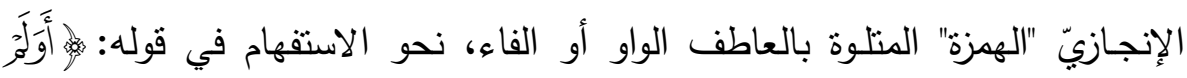

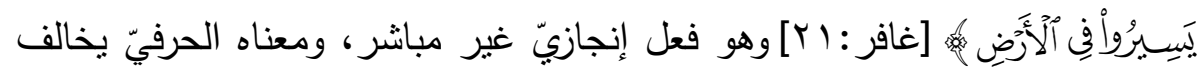
مراد المتكلم؛ وهو الاستقهام عن سير مشركي العرب في الأرض. وقوته الإنجازية

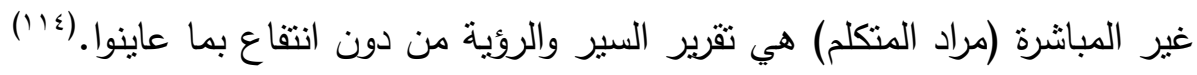

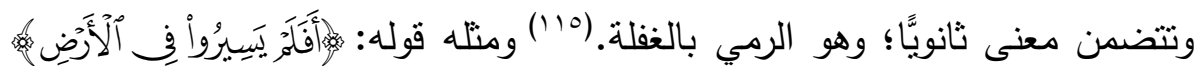

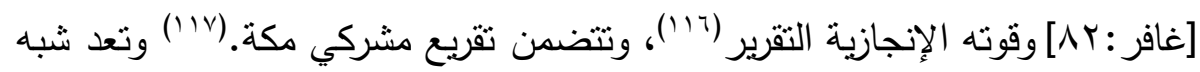

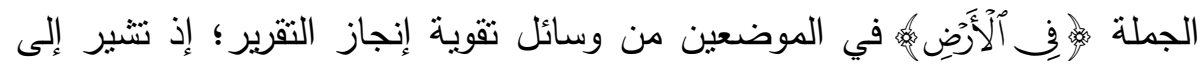
تمكنهم في سيرهم من معرفة أحوال الهالكين من الأمم السابقة.

أما الاستفهام في قوله:

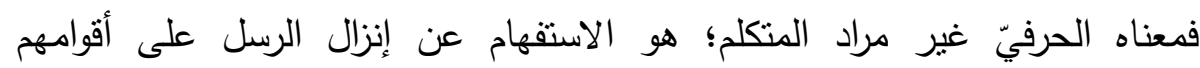

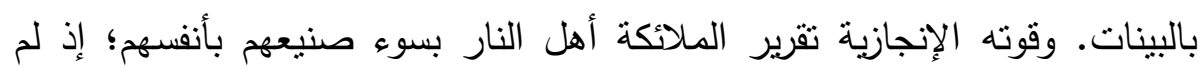

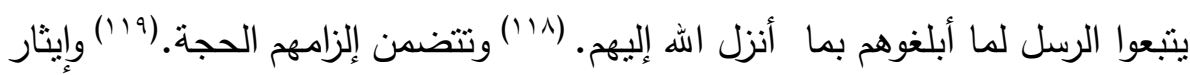

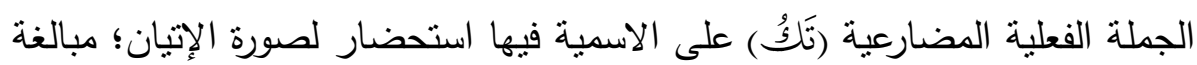

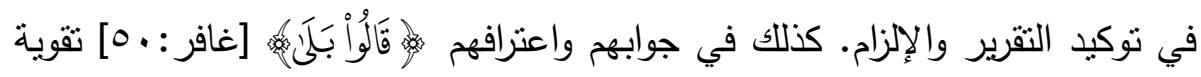

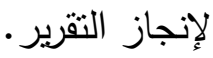

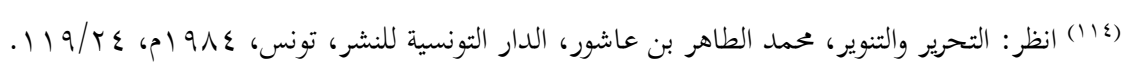

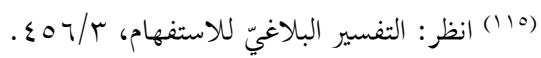

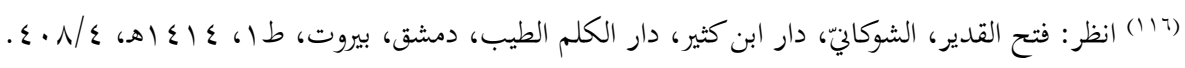

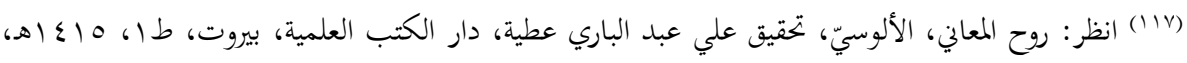
$r \leqslant V / 1 T$

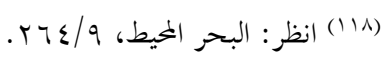

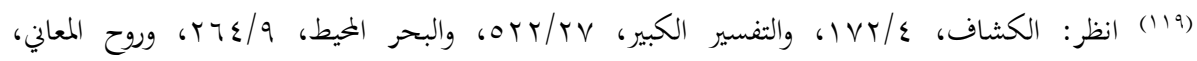


أما في قوله: إنجازيّ غير مباشر، ومعناه الحرفيّ غير مراد المتكلم؛ هو الاستقهام عن علم عاد

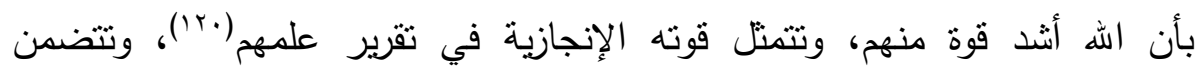

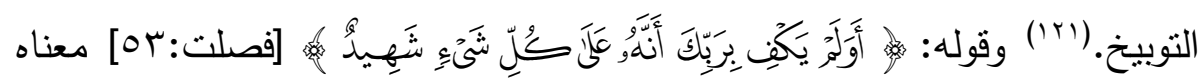
الحرفيّ الاستفهام عن كفاية شهادة الله بصدق النبيّ -صَلَّى اللهُ عَلَيْهِهِ وَستَلَّمَ، وصدق ما نزل به، وقوته الإنجازية تقرير كفاية شهادة الله على صدقه، وصدق ما نزل به، وتتضمن الوعد بتجلية الحق، ونصرته، وإقامة الحجة على المعاندين. (rr') وقوله:

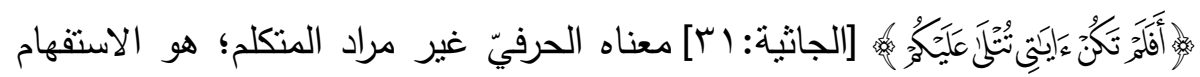
عن إعراض الكافرين وقت تلاوة آيات الله عليهم. وقوته الإنجازية نقرير

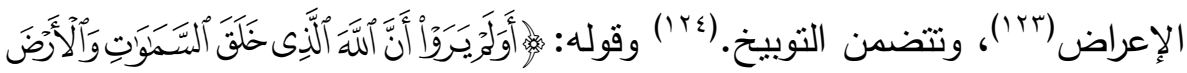

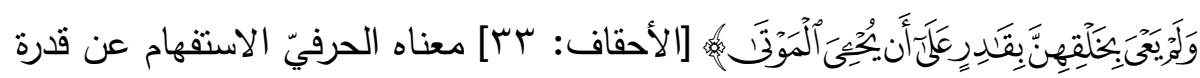
الله على إحياء الموتى، وقوته الإنجازية تقرير المشركين على قدرته على إحياء الموتى، وتتضمن توقيفهم على خلقه السماوات والأرض. (ror)

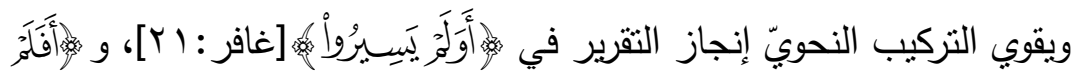

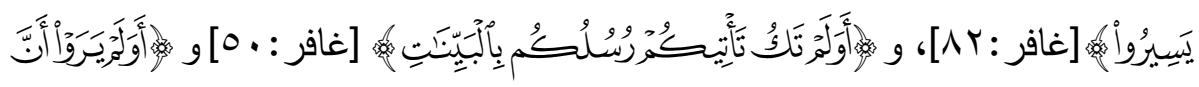

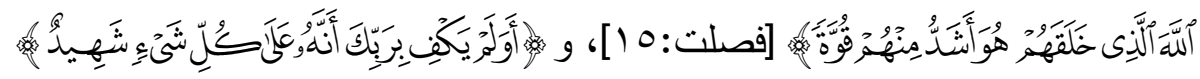

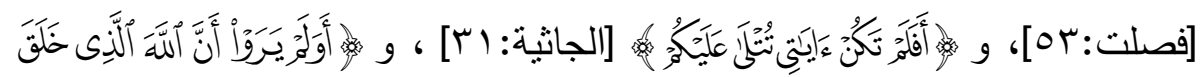

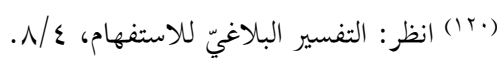

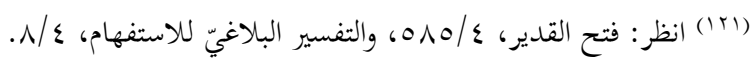

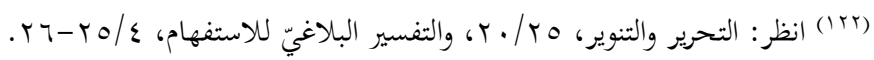

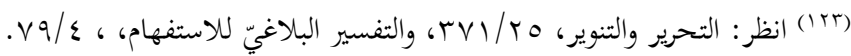

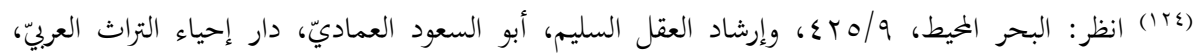

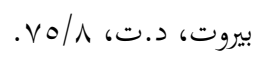

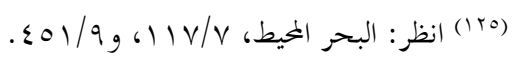




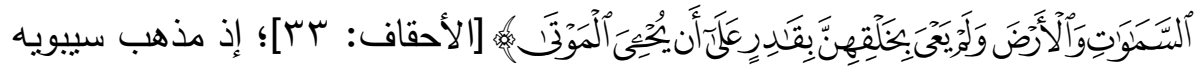

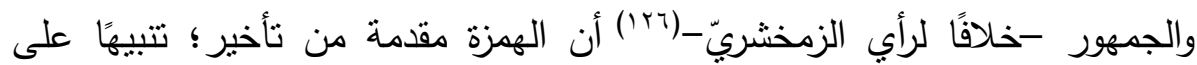

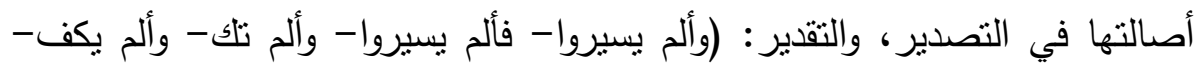

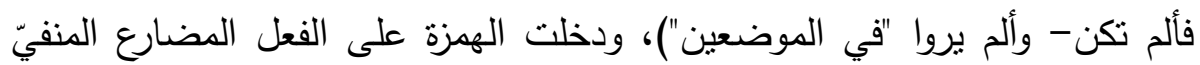

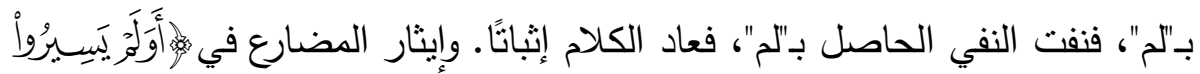

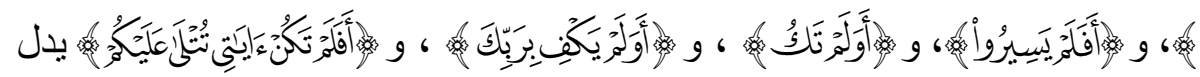
على تجدد السير في الأرض وتكراره، وإنيان الرسل بالبينات لأقوامهم، وشهادة الله على ولى ولى صدق النبيّ وصدق ما نزل به، وتلاوة آيات الهه على الكافرين - ودوامها. ويدل إيثار

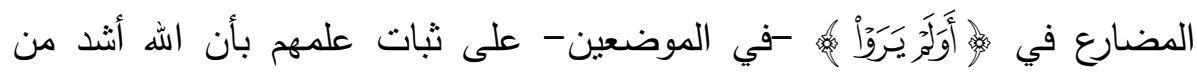
المشركين قوة، وقدرة على إحباء الموتى. وقد يأتي المقرر به بعد الهمزة الداخلة على الجملة المضارعية المنفية بـ"لم" ألى من دون العاطف، نحو قوله: الحرفيّ الاستقهام عن مجادلة المشركين في آيات الله، وقوته الإنجازية تقرير العلم

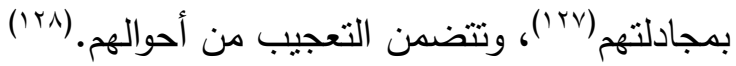
وقد يأتي المقرر به بعد الهمزة جملة اسمية منسوخة بـ"ليس"، نحو قوله:

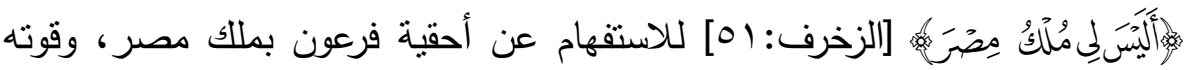

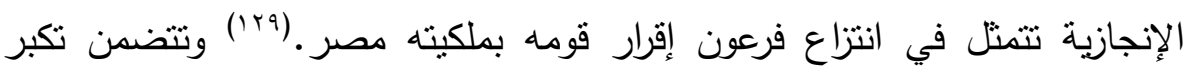

(TrT) انظر في تقرير المذهبين: الكتاب، سيبويه، تحقيق عبد السلام محمد هارون، مكتبة الخابخيّ، القاهرة، طس،

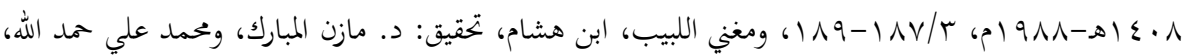

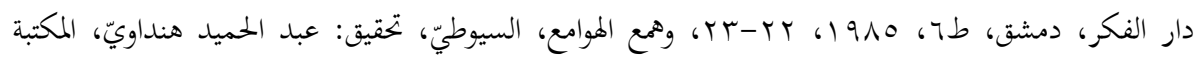

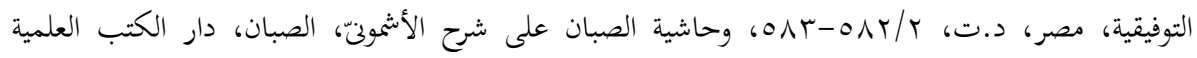

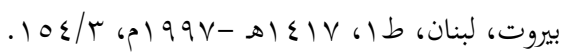

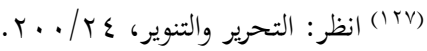
(T)

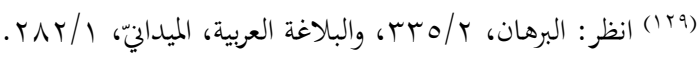
rAN 
فرعون.(·r) وقد قوى التركيب النحويّ إنجاز التقرير ؛ إذ دخلت الهززة على "ليس" في الموضعين، فحصل فيها معنى الإيجاب بعد النفي.('آ) وكذلك زيادة الباء في

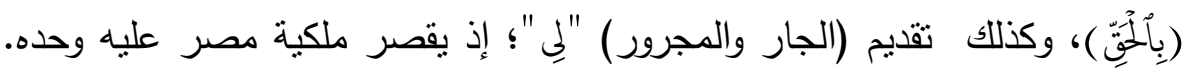

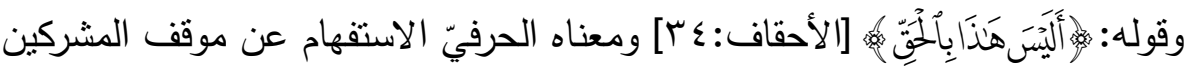

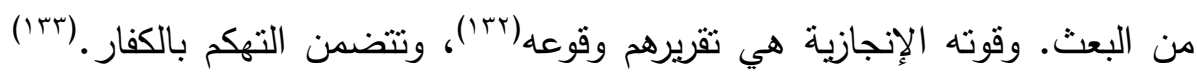

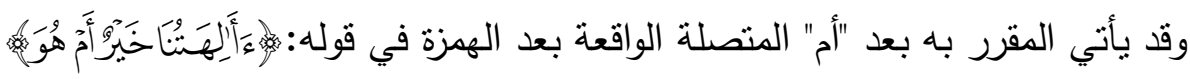

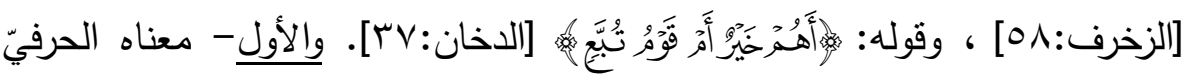

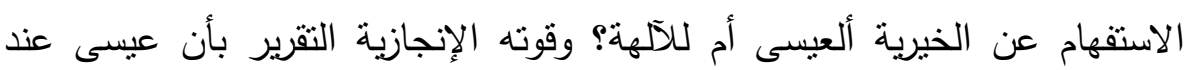

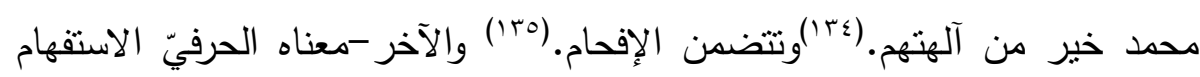
عن الأفضلية: ألمشركي مكة أم لقوم تبع؟ وقوته الإنجازية التقرير بأن قوم تبع أكثر قوة وأعظم نعمة من مشركي مكة، وتتضدن الوعيد. (بrا') أما الاستقهام ب"من" في قوله: الاستفهام عن ملك يوم القيامة، وقوته الإنجازية تقرير الخلق يوم القيامة بأن الملك

(r.r) انظر : الكُليّّات، أبو البقاء الكفويّ، تحقيق عدنان درويش، ومحمد المصريّ، مؤسسة الرسالة، بيروت، د.ت، ص191. (اriا) المسائل الحلبيات، أبو علي الفارسيّ، تحقيق حسن هنداوي، دار القلم للطباعة والنشر والتوزيع،دمشق،

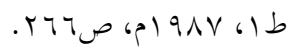

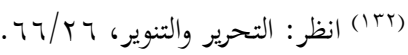

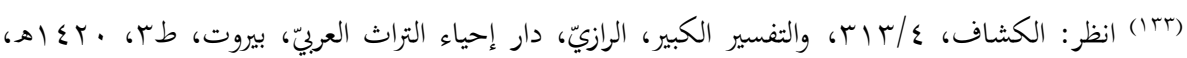
.r./r人

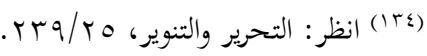

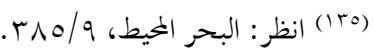
(جrا) انظر: المحرر الوجيز، ابن عطية، تحقيق عبد السلام عبد الشافيّ محمد، دار الكتب العلمية، بيروت، طلها، V0/0 ك 


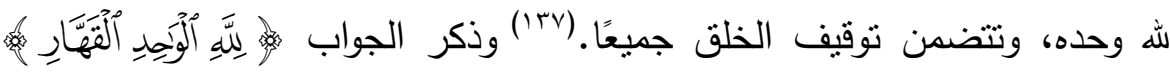
[غافر:17 1 ] يقوي إنجاز التقرير؛ إذ جاء ليؤكد حقيقة أن الملك لله وحده. ومثلكه قوله: والأول- معناه الحرفيّ الاستقهام عن خالق السماوات والأرض، وقوته الإنجازية هي

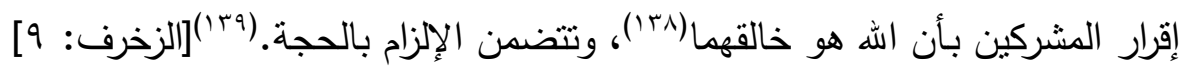
أما الموضع الآخر فمعناه الحرفيّ الاستفهام عن الخالق، وقوته الإنجازية تقرير

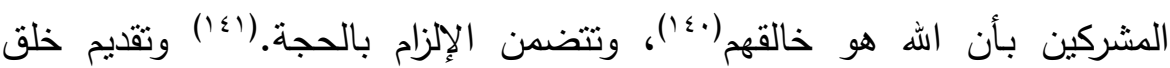

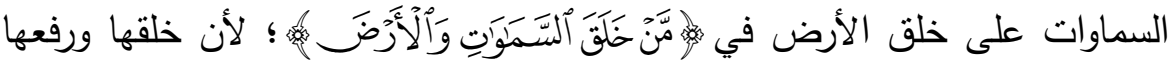
أدخل في باب التقرير الذي من أجله سيق الاستقهام. ثم عطف عليها خلق الأرض؛ لأن خلقها يليها فخامة وعظمة. وتكرار (خَلَعَهُنَّ) بعد (خَلَقَ) يقوي إنجاز التقرير

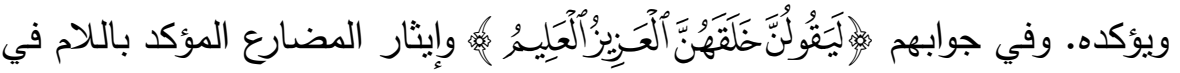
جواب القسم تقوية لإنجاز التقرير ؛ إذ في الجواب إقرار بأن اله هو خالق السماوني والأرض، وفي اللام توكيد القول، وفي إيثار المضارع-في الموضعين - دليل على تجدد قولهم واستمراره، وتكرار اعترافهم في الحال والاستقبال.

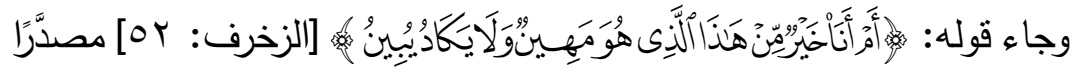

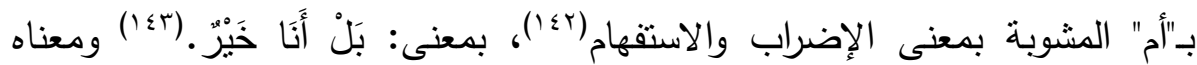

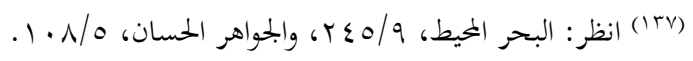

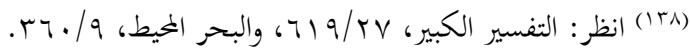

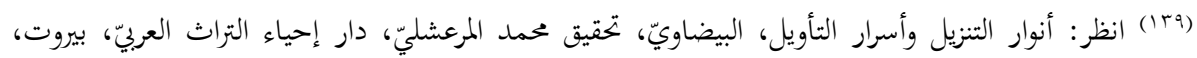
. NV/0 6 (ه)

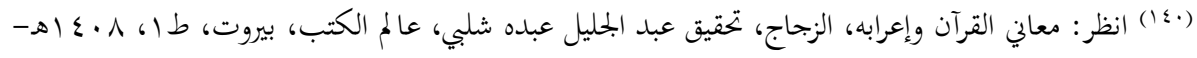
. \&) \&/\& (p) 914

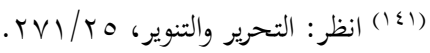

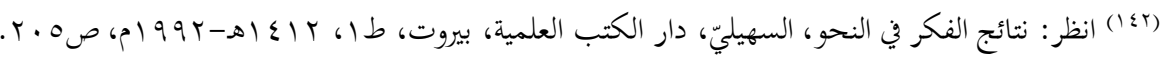

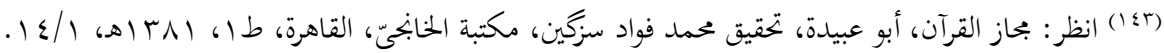


الحرفيّ الاستقهام عن أفضلية فرعون على موسى. وقوته الإنجازية تقرير قومه بعظمة

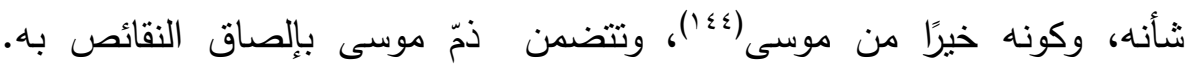

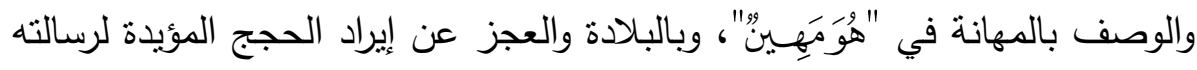
بادعاء العيب في نطقه في "وَلَايَكَادُيُبِينُ " من مقويات إنجاز التقرير بأفضلية فرعون.

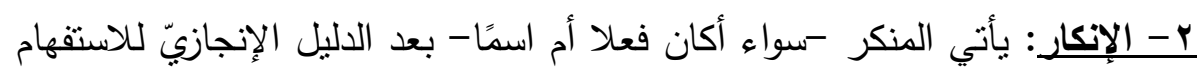

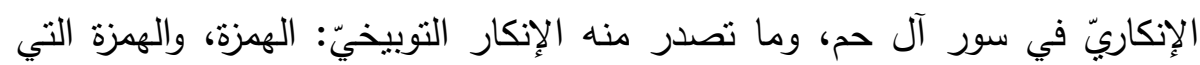
تتضمنها "أم" المنقطعة؛ بمنزلة (بل والهمزة)، وهل، وما، ومن، وأنّى، وأيّ، وأين. أما التكذيبيّ منه فورد بـ: الهمزة، والهمزة التي تتضمنها "أم" المنقطعة؛ بمنزلة (بل والهمزة)، وما، ومن. والاستفهام غير المباشر في المواضع التالية فعل إنجازيّ غير مباشر، معناه الحرفيّ يخالف مراد المتكلم، وله قوة إنجازية غير مباشرة، تتضمن معنى ثانويًا. ومن شواهد الإنكار التوبيخيّ بالهمزة، متلوة بالفعل المضارع قوله:

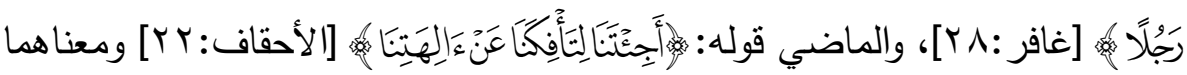
الحرفيّ الاستفهام، أما الأول فلاستفهام عن علة القتل من دون موجب، وقوته

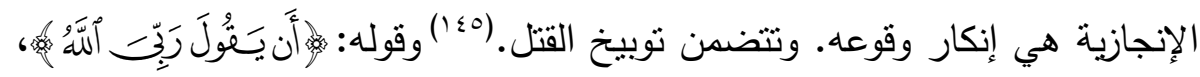

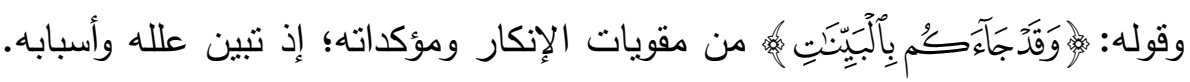

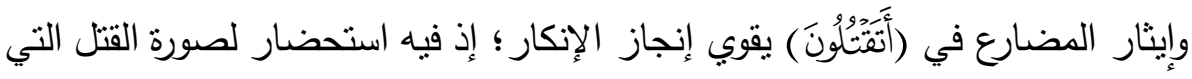

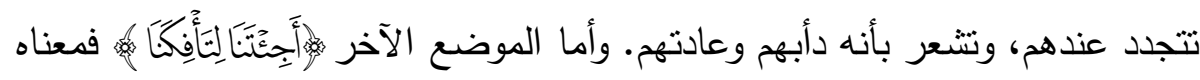
الحرفيّ الاستقهام عن مجئ هود -عليه السلام- لقوم عاد لصرفهم عن عبادة

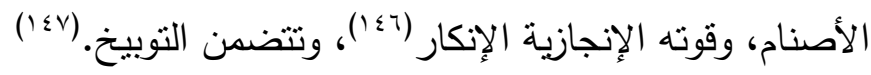

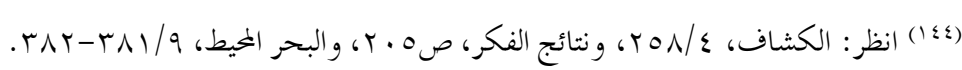

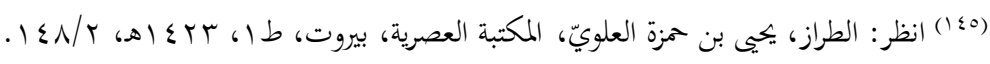

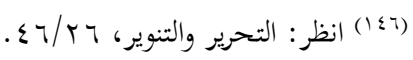

$$
\begin{aligned}
& \text {. }
\end{aligned}
$$


ومنه الاستقهام بـ"الهمزة" المتلوة بحرفي العطف الواو والفاء، أما المتلوة بالواو

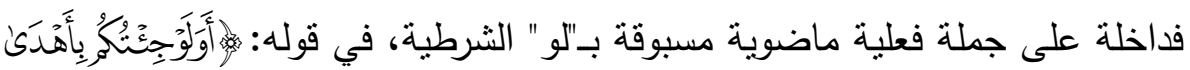

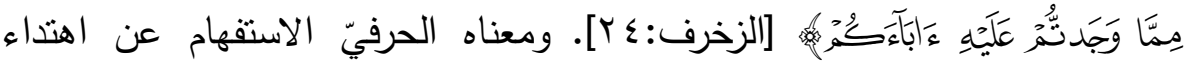
المشركين إن جاءهم النبيّ بدين أهدى من دين آبائهم وأحق، وقوته الإنجازية إنكار

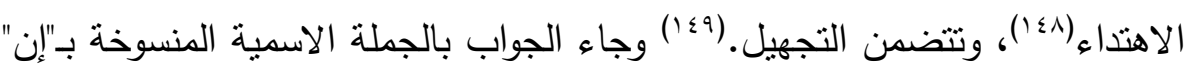

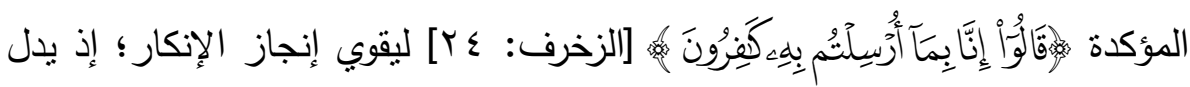
على استمرار كفرهم بما أرسل به النبيّ -صَلَّى اللهُ عَلَيَهْهِ وَسَلَّمَ- ودوامهم عليه. كذلك

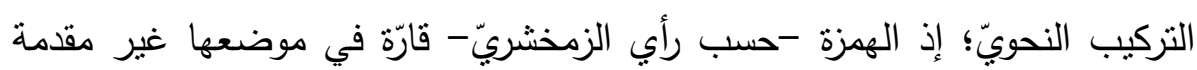
من تأخير، ومدخولها -المعطوف عليه بالواو - محذوف، وتقديره: أتتبعون آباءكم ولوجئتم بدين أهدى من دين آبائكم".(10.) أما التقدير عند سييويه والجمهور : (وألو جئنكم)، والهمزة مقدمة من تأخير ، داخلة على الفعل (جئتكم) دخولًا مباشرًا من دون لهن أن يفصل بينها وبين الفعل حرف نفي، فنفت هي الفعل، وتحقق الإنكار، فاستوى المذهبان في إفادة الإنكار • وأما المتلوة بـ"الفاء" فداخلة على جملة فعلية مضارعبة، في قوله: قطع الذكر عن المسرفين في الكفر والإعراض عما نزل من القرآن، وقوته الإنجازية إنكار قطع الإرشاد(101)، وتتضمن التجهيل. وقد دعم التركيب النحويّ إنجاز الإنكار على مذهب سيبويه والزمخشريّ؛ إذ التقدير على مذهب سيبويه والجمهور (فأنضرب

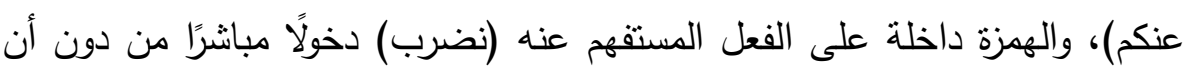
يفصل بينها وبين الفعل حرف نفي، فنفت هي الفعل، وتحقق الإنكار ـ وأما الزمخشري فعد الهمزة قارّة في موضعها غير مقدمة من تأخير، وأن مدخولها -المعطوف عليه

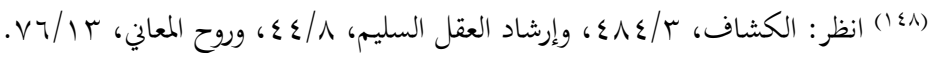

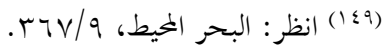

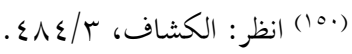

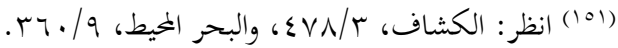


بالواو - محذوف، وتقديره: (أنهملكم فنضرب عنكم الذكر صفحًا)، فتحقق الإنكار، واستوى المذهبان في إفادة الإنكار .(10r) بالمون ومنه ما جاء بالهمزة التي تتضمنها "أم" المنقطعة بمنزلة "بل والهمزة"، في

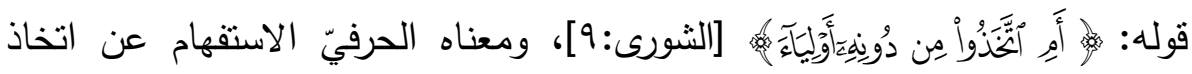
الظالمين أولياء من دون الله وقوته الإنجازية إنكار الاتخاذ(بr)، وتتضمن التوبيخ.(10) ويعد ذكر الجواب والتعبير بالجملة الاسمية في الجواب في قوله الإنهابه

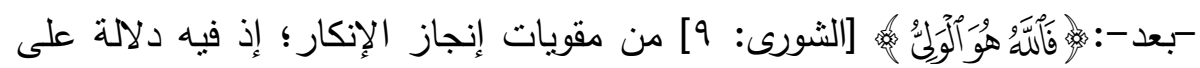
ثثبوت الولاية ودوامها، وقصرها على لفظ الجلالة (فَلَّْهُ) قصرًا حقيقيَّا، عن طريق تعريف الطرفين، وضمير الفصل (هوَ).

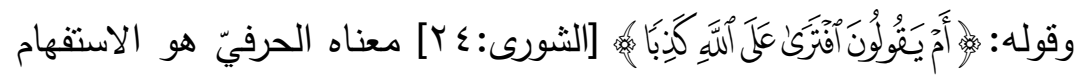
عن ادعاء المشركين كذب النبيّ على الله، وقوته الإنجازية إنكار هذا الادعاء.(100)

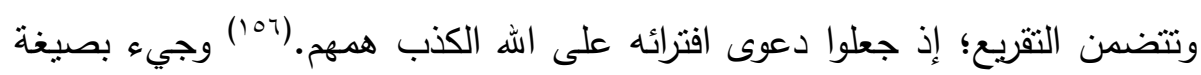
المضارع (يَقُولُونَ) لتقوية إنجاز الإنكار، ليتوجه هو والتقريع إلى استمرارهم على هذا

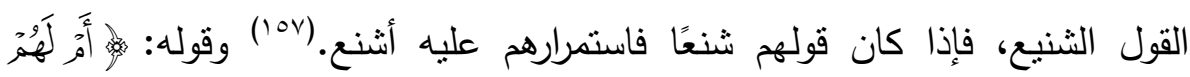

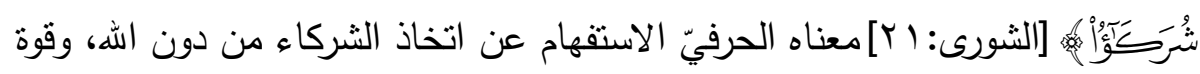

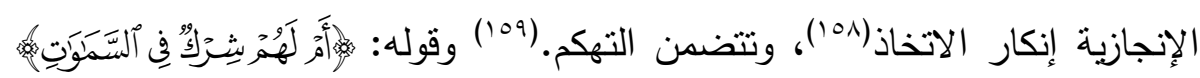

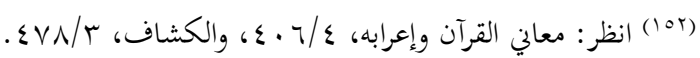

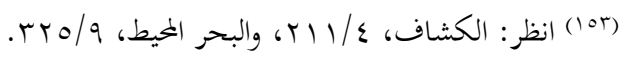

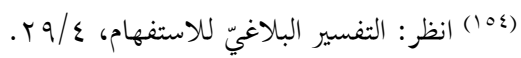

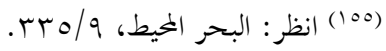

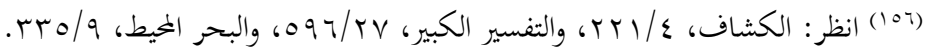

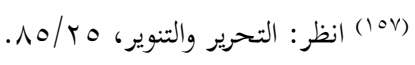

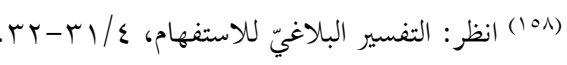

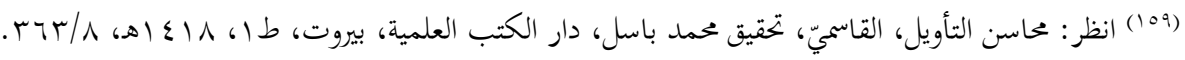


[الأحقاف:؛] معناه الحرفيّ الاستقهام عن شراكة آلهتهم الله في خلق السماوات، وقوته

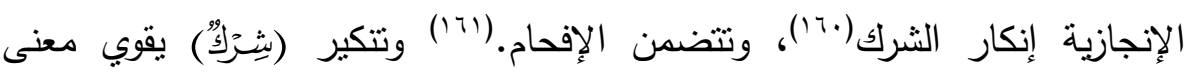
الإنكار؛ إذ يفيد انعدام الثريك قطعًا. وفي تضمّن (أم) التي بمعنى (بل) همزة

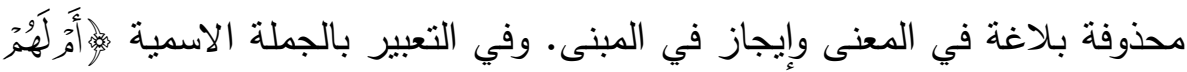

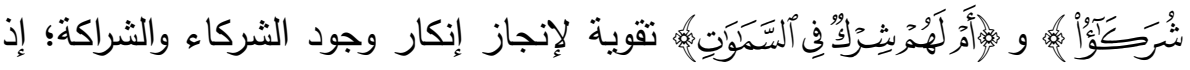
تدل على دوامه واستمراره من دون انقطاع.

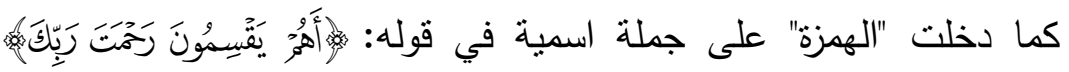
[الزخرف:Yr]، ومعناه الحرفيّ الاستقهام عن أن يكون المشركون هم المتولون قسم رحمة الله، وقوته الإنجازية هي إنكار ذلك(rآ)، وتضمن التعجيب من جهل

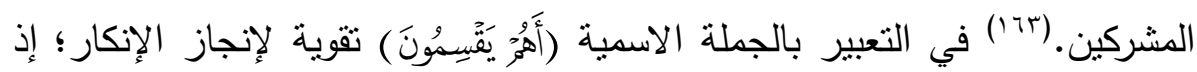
تدل على ثبوتههم في ادعائهم، واستمرارهم من دون انقطاع.

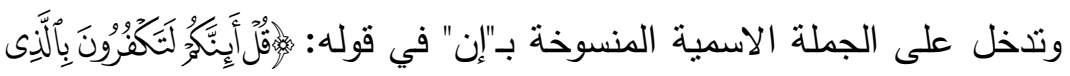

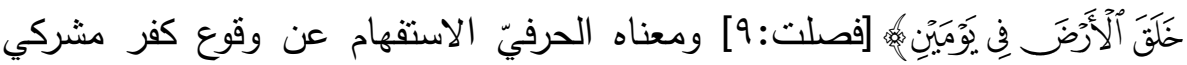
العرب باله بإثبات الثركاء، وقوته الإنجازية إنكار ذلك(ئ1)، وتتضمن تهديد

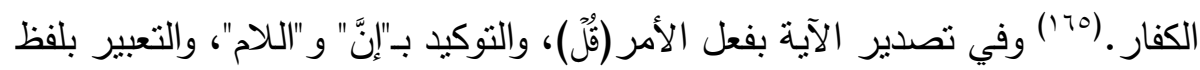

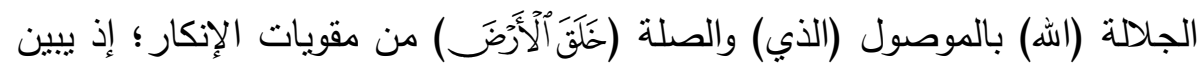

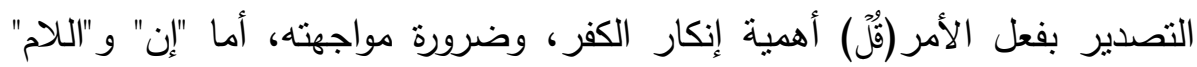

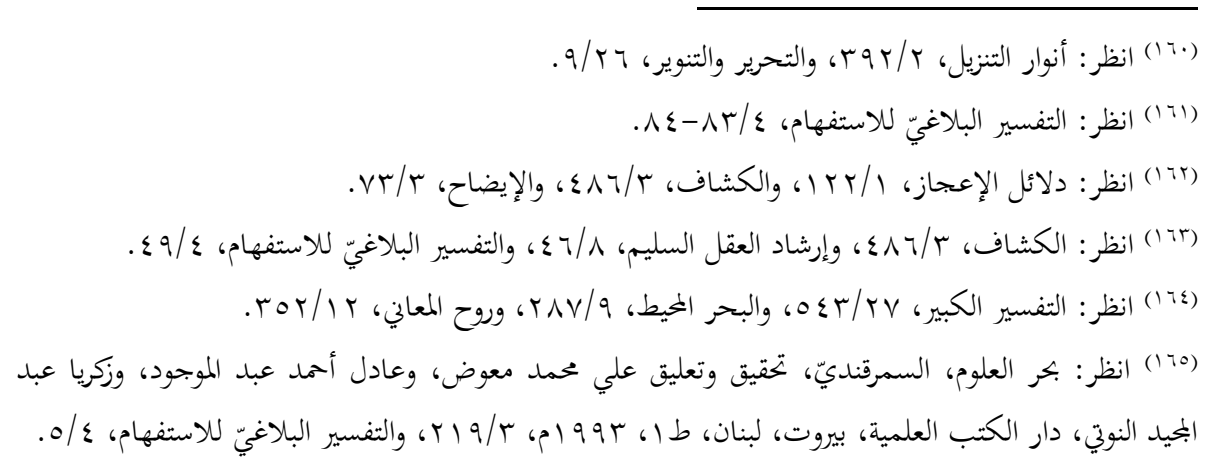


فلتأكيد الإنكار وتغليظه، أو للإشعار بأن كفرهم من البعد بحيث بنكر العقلاء وقوعه، فيحتاج إلى التأكيد، وفي التعبير بلفظ الجلالة (اله) بالموصول (الذي) والصلة (خَلَقَ

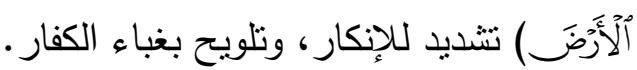

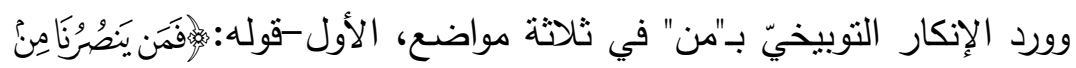

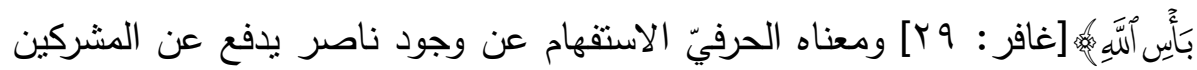

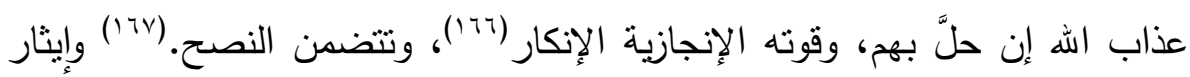
المضارع "يَضُ-ُنَّا" من مقويات الإنكار ؛ إذ بضفي المقام علي المضارع دلالة الاسم الإن على الثبوت والاستمرار والدوام؛ وليس التجدد والحدوث الذي يتخلله انقطاع. والثاني -

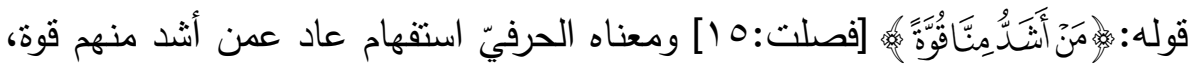
وقوته الإنجازية إنكار أن يكون في الوجود من هو أقوى منهم ونفيه(1)، (1)، وتتضمن

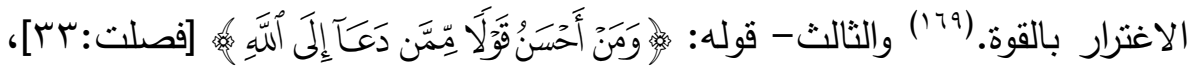
ومعناه الحرفيّ الاستفهام عن أحسن الأقوال الداعية إلى الله، وقوته الإنجازية

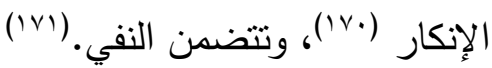

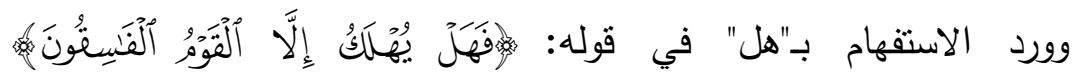
[الأحقاف:10]، ومعناه الحرفيّ الاستقهام عن هلاك الفاسقين، وقوته الإنجازية

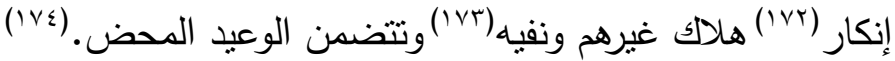

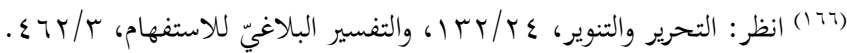
)

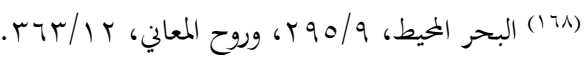

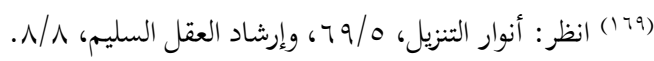

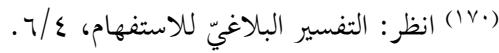

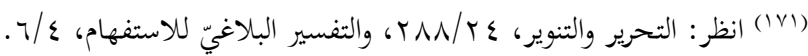

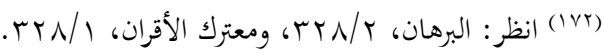

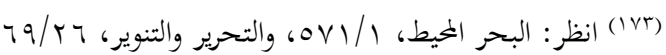

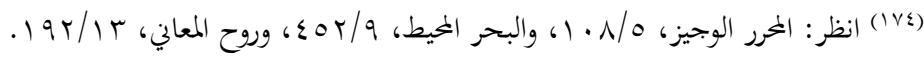


وقوى أسلوب الحصر -بالنفي وإلا- إنجاز الإنكار ؛ إذ حصر الهلاكى في القوم الفاسقين.

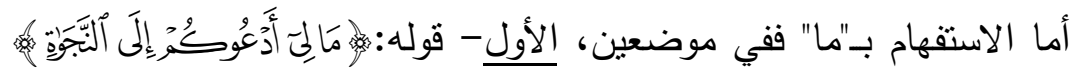

[غافر: 1؟] ، ومعناه الحرفيّ الاستفهام عن سبب دعوة مؤمن آل فرعون قومه إلى الى

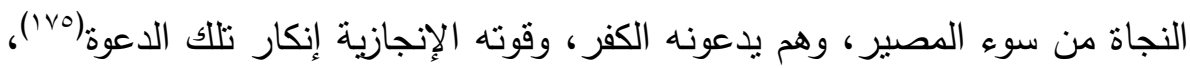

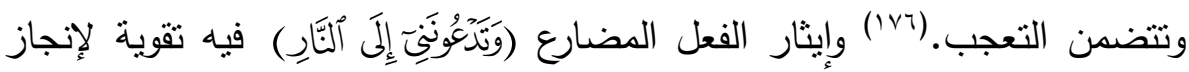
الإنكار؛ إذ فيه الدلالة على تكرار دعوتهم مؤمن آل فرعون إلى الكفر الموجب خلوده

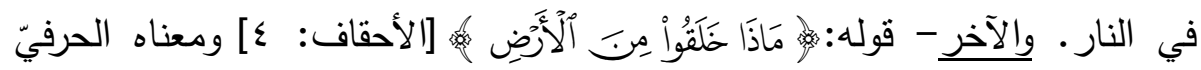

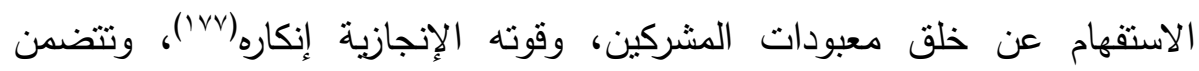

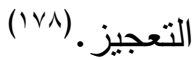

وللاستفهام بـ"أَنّ" موضعان، أحدهما - قوله:

ومعناه الحرفيّ الاستقهام عن انصراف المشركين عن توحيد الله إلى إثرالك غيره به،

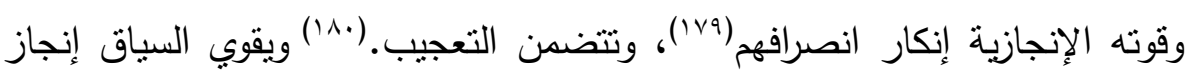

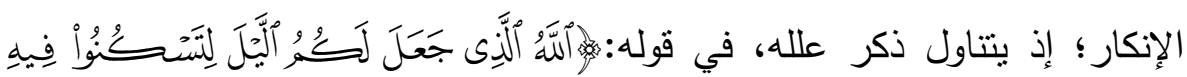

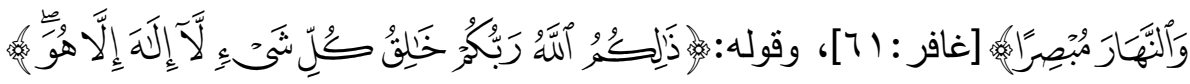

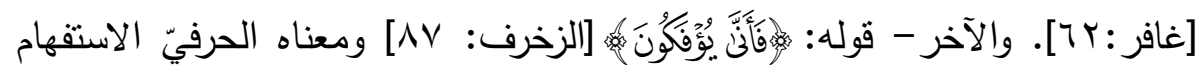
عن انصراف المشركين عن عبادة الله، وتتمثل قوته الإنجازية في إنكار انصرافهم

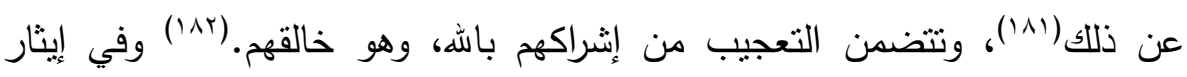

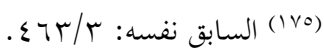

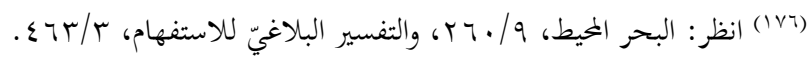

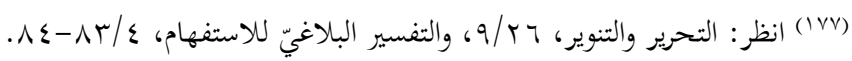
(IV^)

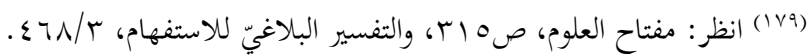

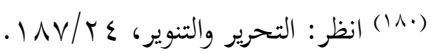

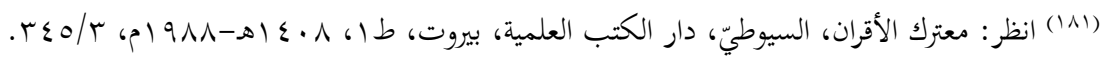

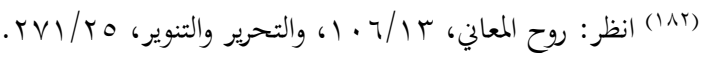
एव7 


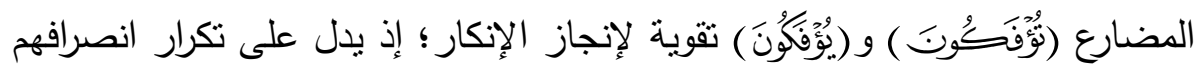
عن عبادة الله، واستمرارهم في ذللك، وحتى صار هذا من عادتهم ودأبهم. والاستقهام بـ"أبيّ" في قوله:

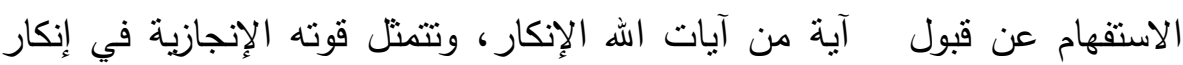

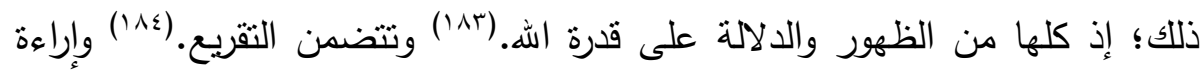

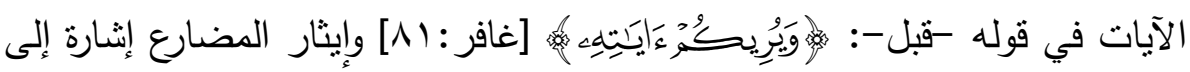
شمولها الأوقات كلها، مما يقوي إنجاز الإنكار، ويؤكده، ويجعله مترتبًا على الإراءة.

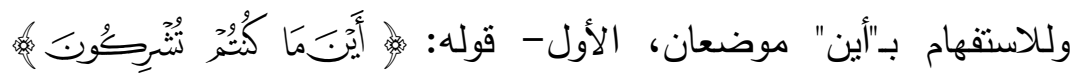

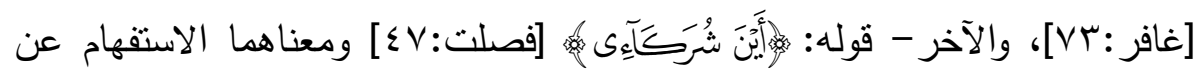

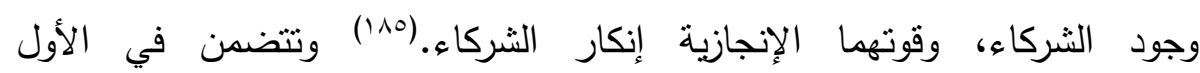
التقريع(ז^)، وفي الآخر التهم.(AY(') ومن مقويات إنجاز الإنكار في الموضع الأول:

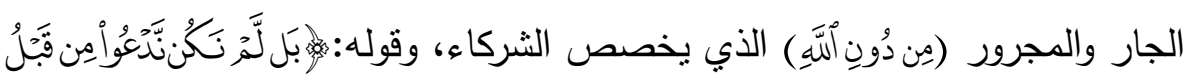

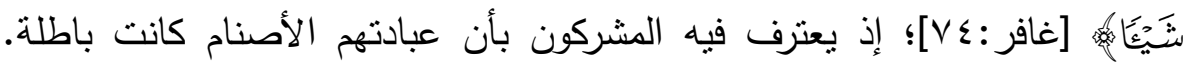

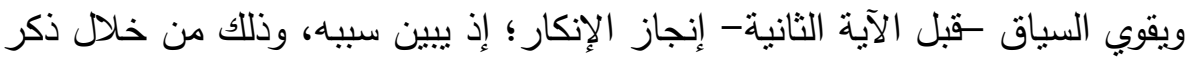
بعض خصائص الألوهية التي لا يشاركه أحد في الإحاطة بها، وهي: استئناره بعلم

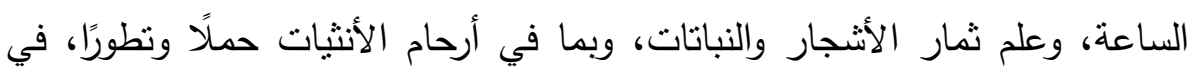

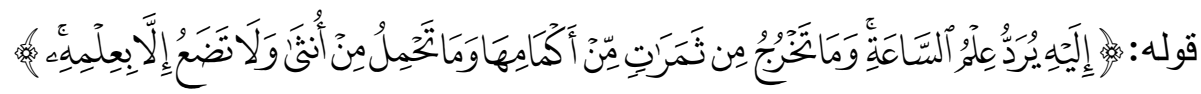
[فصلت: $[\leqslant \vee]$

أما الإنكار التكذيبيّ فقد ورد بـ: الهمزة، والهمزة التي تتضمنها "أم" المنقطعة بمنزلة "بل والهمزة"، وما، ومن. أما الاستفهام بـ"الهمزة" ففي موضعين، الأول - داخلة

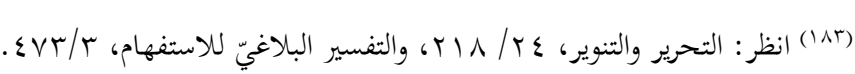

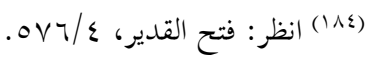

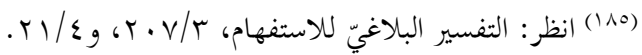

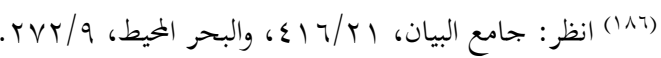

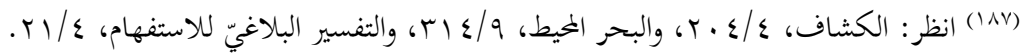


على الاسمية المتلوة بالواو في قوله: [الزخرف: 1 1] ومعناه الحرفيّ الاستفهام عن خلق البنات والبنين، وقوته الإنجازية إنكار بدعة تقسيم المشركين الخلق، واستئثارهم بالذكور ، وترك البنات لله؛ إذ لم يقر الله

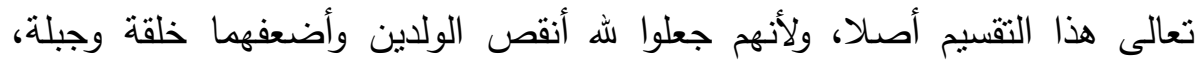

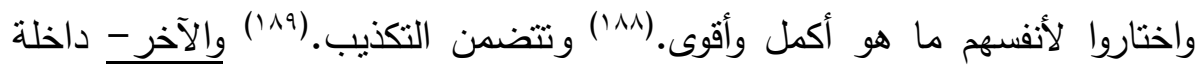

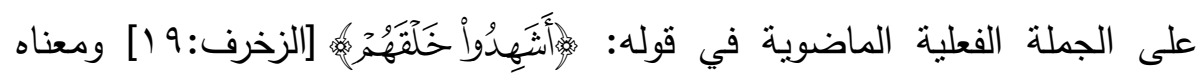
الحرفيّ الاستفهام عن مشاهدة المشركين خلق المائكة، ووصفهم بأنهم إناث، وتتمنل

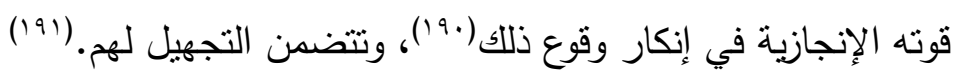

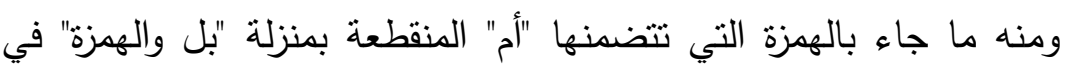

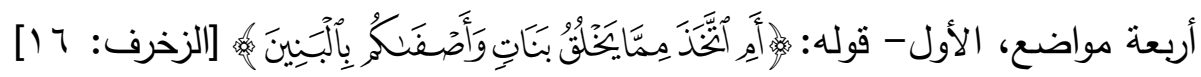
ومعناه الحرفيّ الاستقهام عن جعل المشركين البنات لله والبنين لهم، وقوته الإنجازية

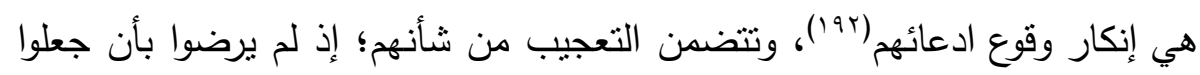

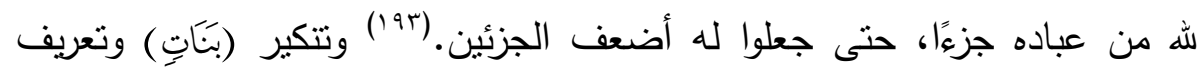

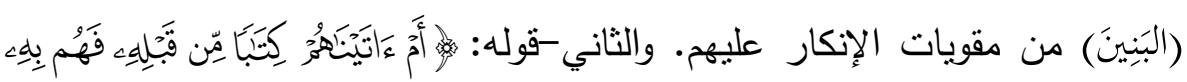

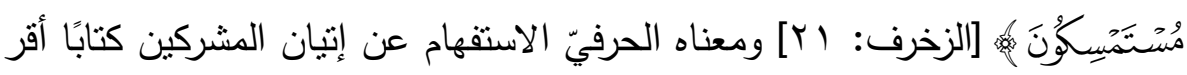
الله فيه بما كفروا به، وقسمتهم لخلق الله، وتخصيص بعضه لهم وبعضه لله،

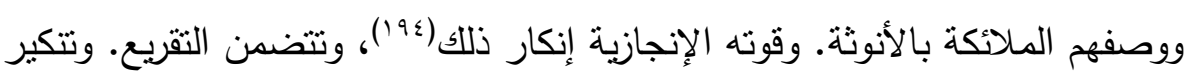

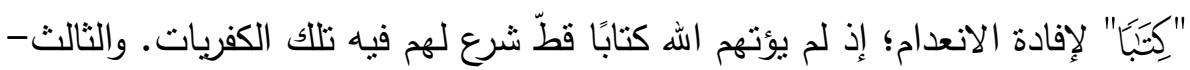

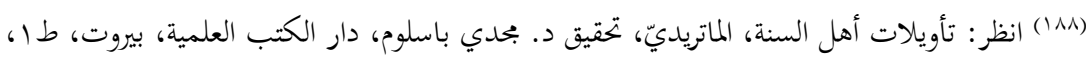

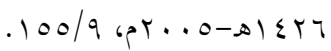

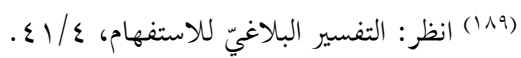

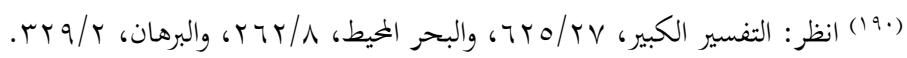

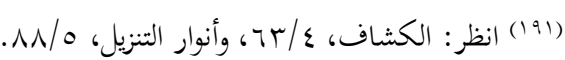

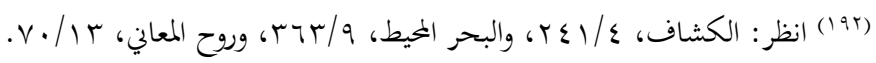

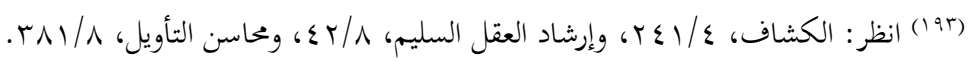

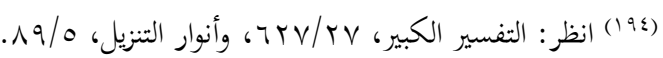
r१ᄉ 


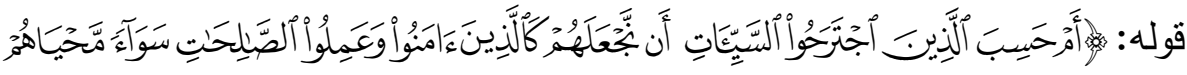

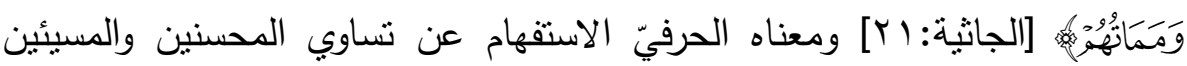

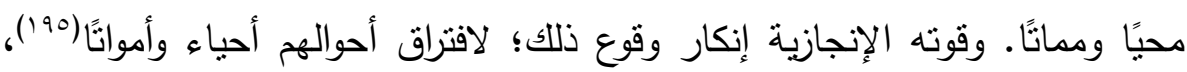

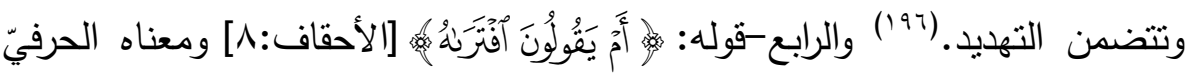

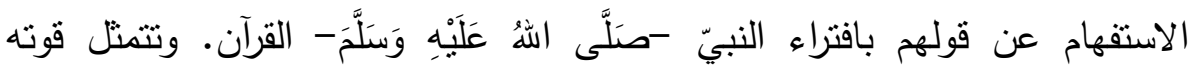

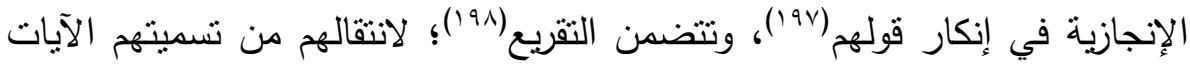

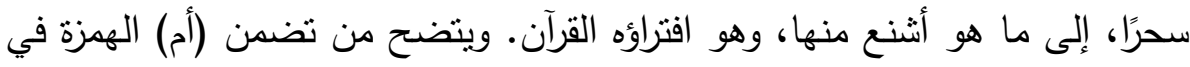

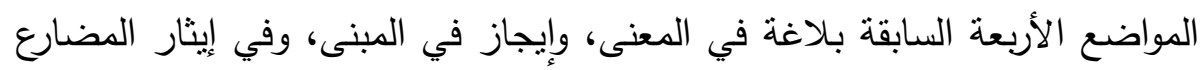

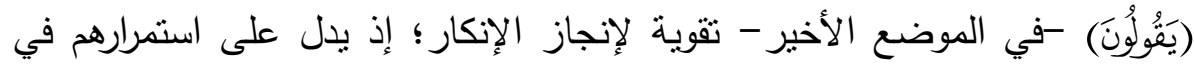
القول بافتراء النبيّ القرآن ودوامهم.

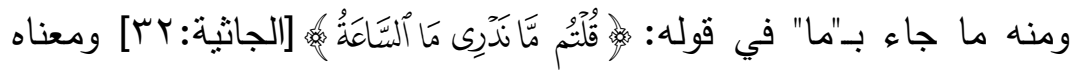
الحرفيّ استفهام الكفار عن وقوع البعث، وقوته الإنجازية إنكار وقوعه، وتتضيناء

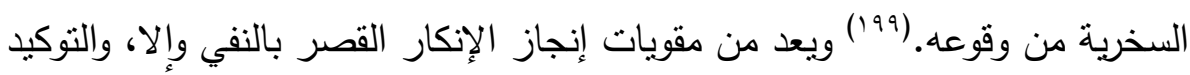

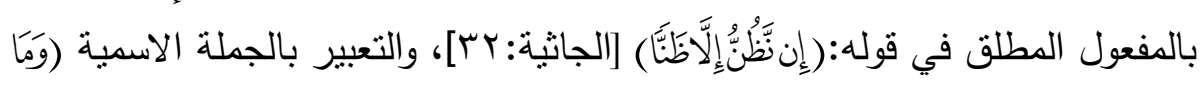

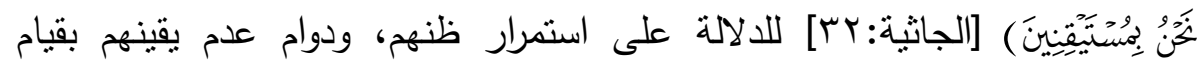

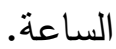

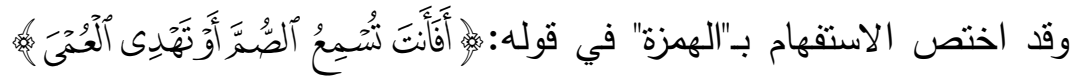
[الزخرف:•؛] بكونه ليس موضعًا من مواضع الإنكار التوبيخيّ أو التكذيبيّ؛ نأدبًا

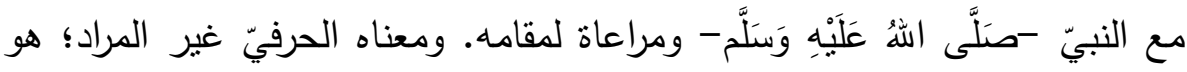

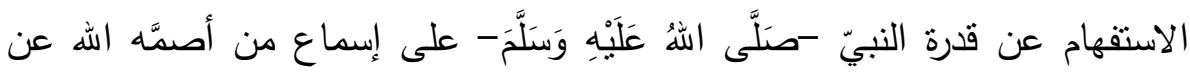

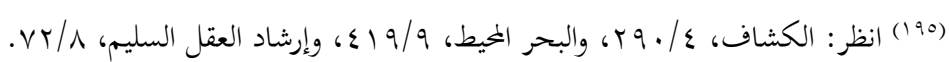

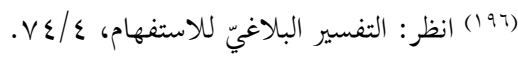

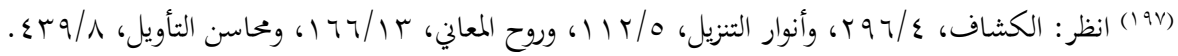

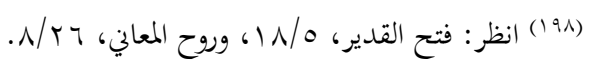

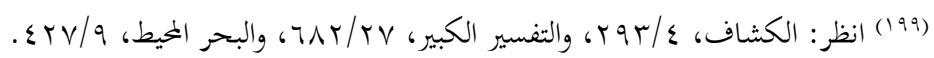


سماع الحق، أو هداية من أعمى قلبه عن طريق الهدى. وقوته الإنجازية إنكار وقوع

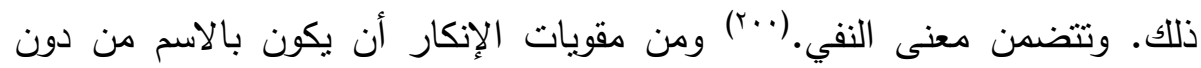

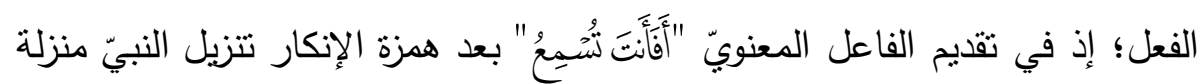

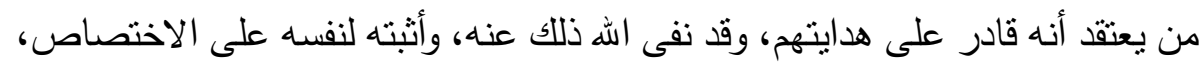

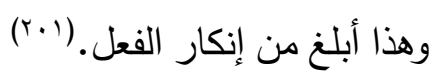

وهناك ثلاثة مواضع يحتمل الاستفهام فيها التقرير والإنكار وفق توجيه المعنى

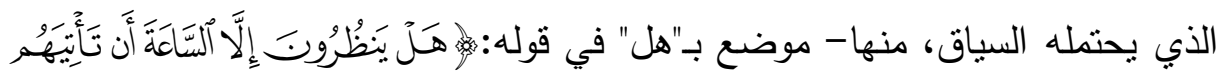

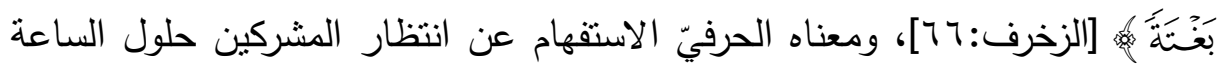

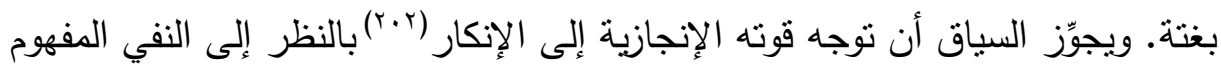

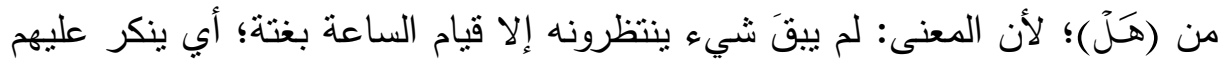

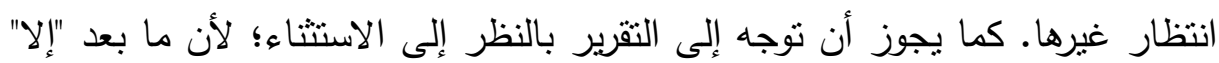
مثبت، ويكون المعنى: أن الأمر الوحيد الذي ينتظرونه أو ينتظرهم هو قيام الساعة.

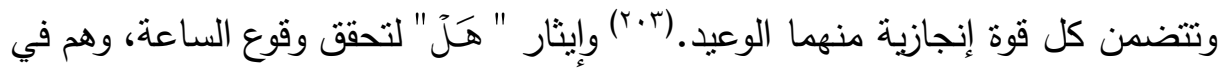
غفلة عنها، فتبهتهم. وإيثار المضارع "يَظُروروتَ" من مقويات التقرير أو الإنكار؛ إذ يضفي المقام علي المضارع دلالة الاسم على الثبوت والاستمرار والدوام؛ وليس التجدد

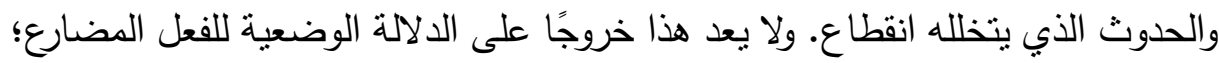

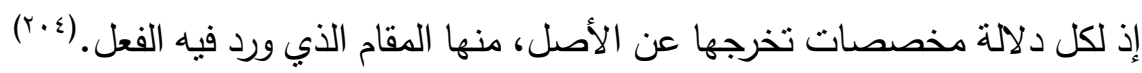

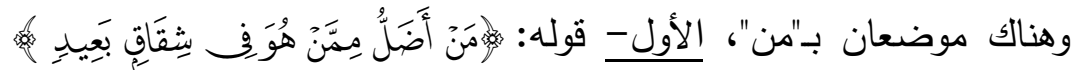

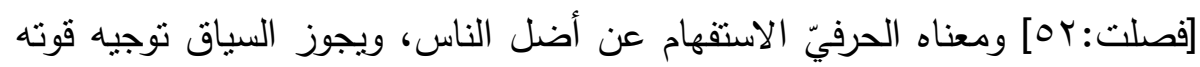

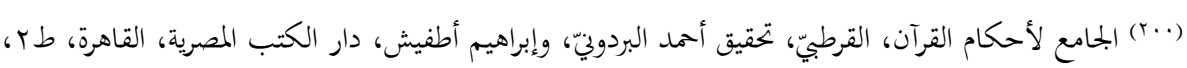

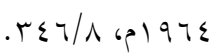

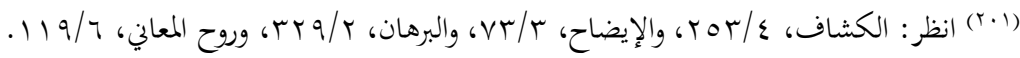

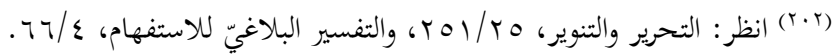

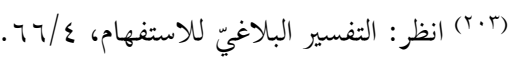

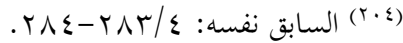




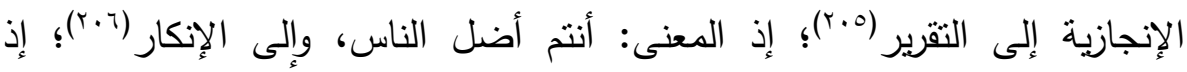

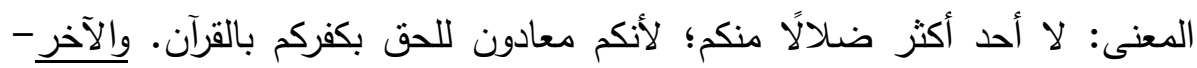

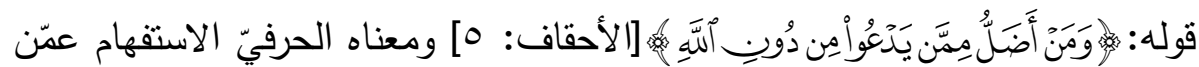

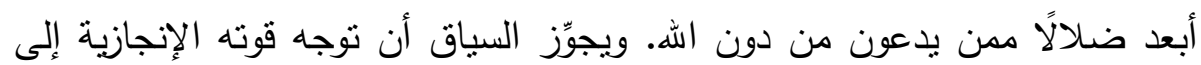

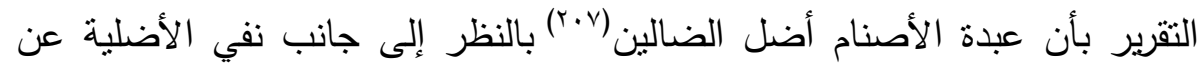

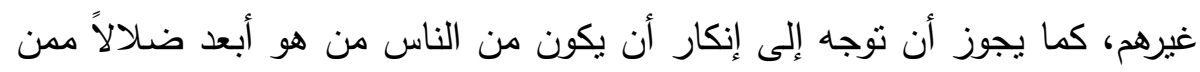

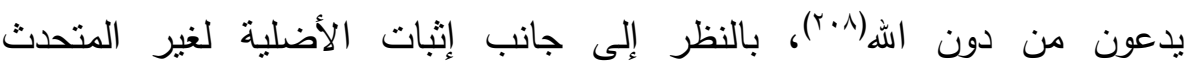

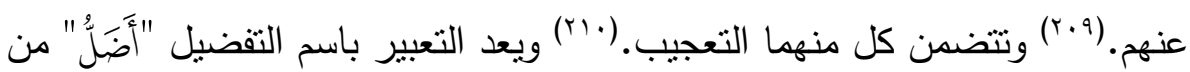
مقويات إنجاز التقرير أو الإنكار في الآيتين. r- النفي: اقتصر على مجيئه ذا قوة إنجازية غير مباشرة، تتضمن معنى ثانويًّا،

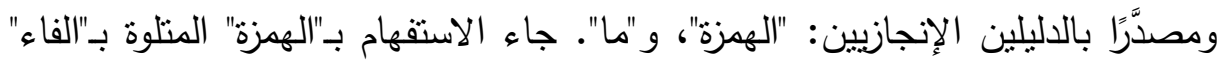

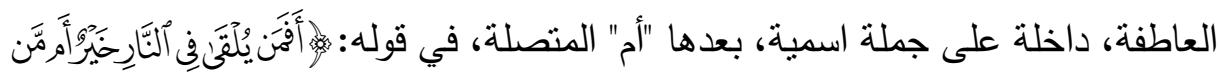

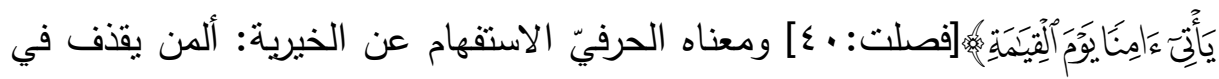

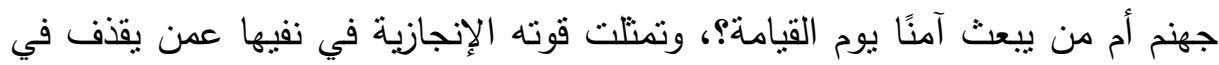
جهنم، وإثباتها لمن يبعث آمنا يوم القيامة('(r)، وتتضمن التوبيخ المستعمل في التتبيه

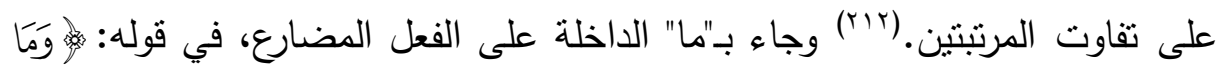

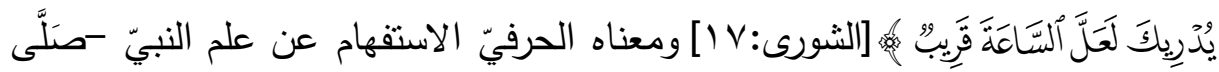

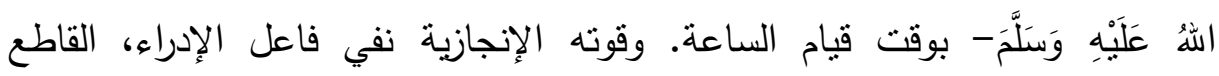

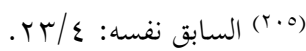

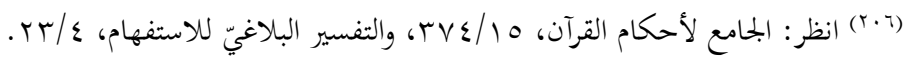

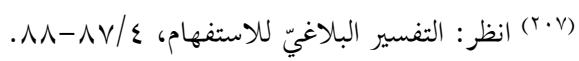

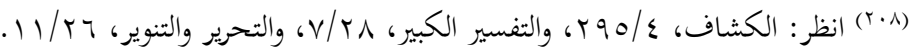

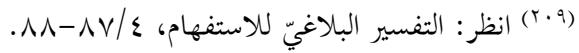

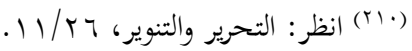

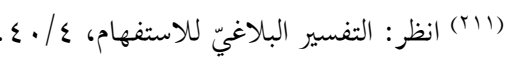

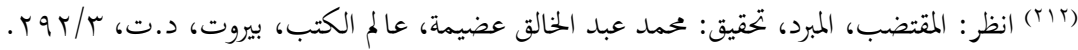


المؤبد.(r/(r) وتتضمن تهديد السائلين عن وقتها على وجه الإنكار والتهكم.(؟) وإيثار المضارع "يُدِِِيكَ" يقوي النفي؛ إذ يعم النفي جميع الأوقات، ويضفي المقام علي وني المضارع دلالة الاسم على الثبوت والاستمرار والدوام؛ وليس التجدد والحدوث الذي يتخلله انقطاع.

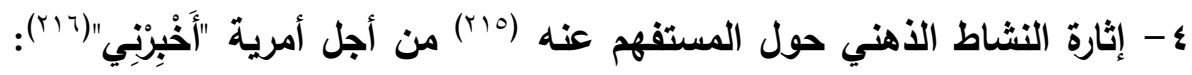

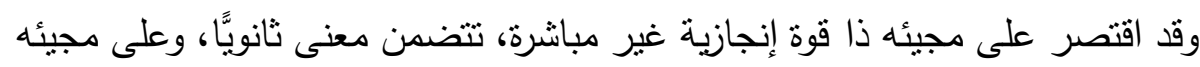

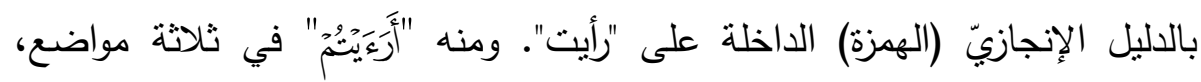

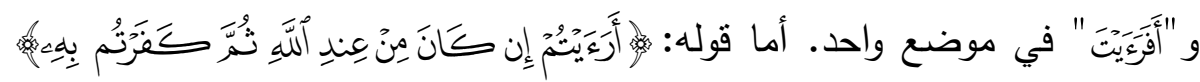

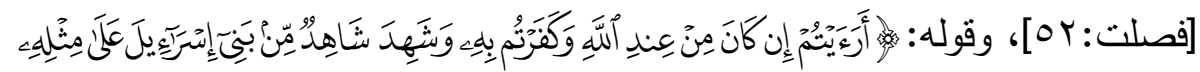

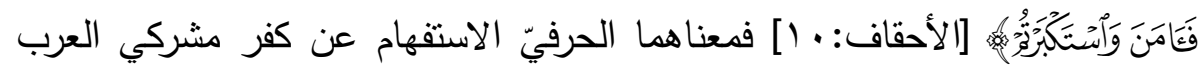
بالقرآن، وتتمثل قوتهما الإنجازية في إثارة النشاط الذهني حول كون القرآن من عند الندان

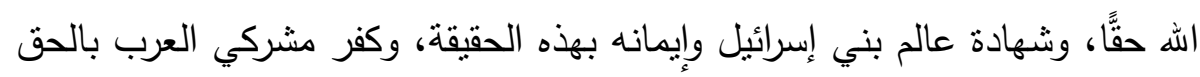

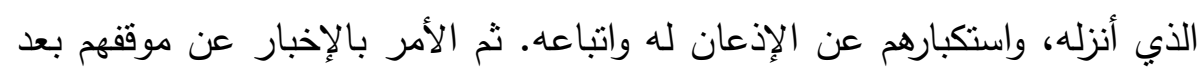

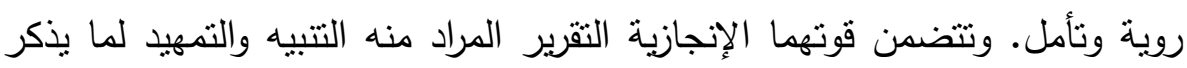

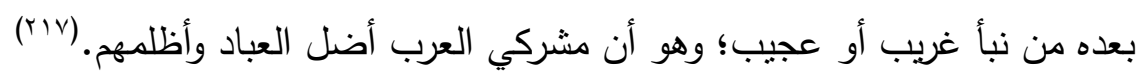

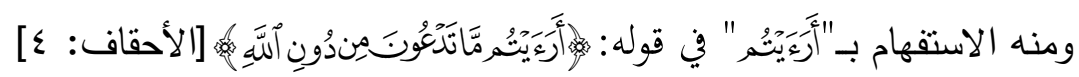
ومعناه الحرفيّ الاستفهام عن حقيقة معبودات المشركين، وتتمثل قوته الإنجازية في

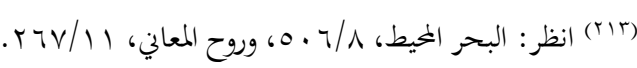

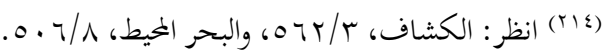

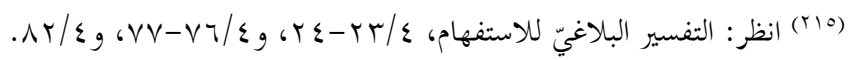

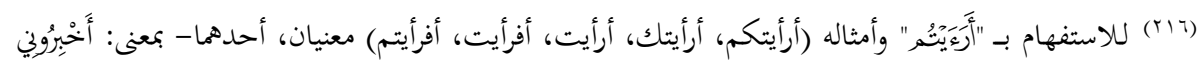

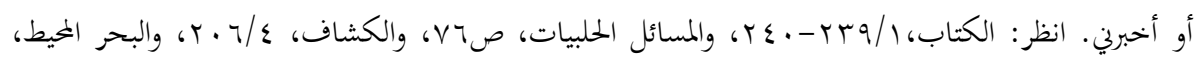

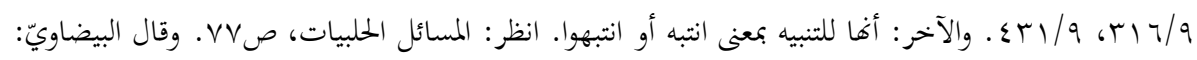

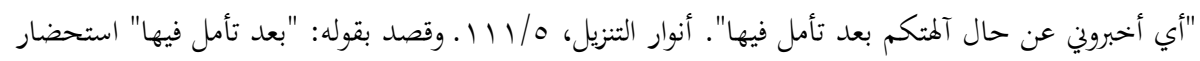

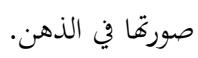

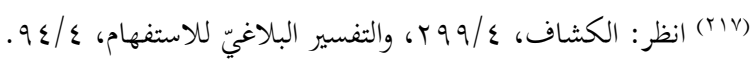
s.r 
إثارة النشاط الذهني حول معبودات المشركين، والتوطئة والإخبار -بعد رويَّة وتأمُّل -

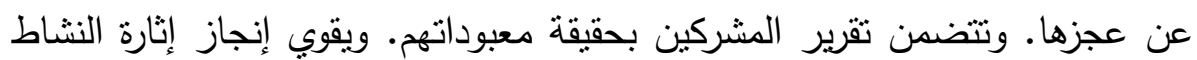
الذهنيّ تصدر الآيات بفعل الأمر (قُّ) ؛؛ للإشعار بأهمية المقول المأمور بقوله، وكونه

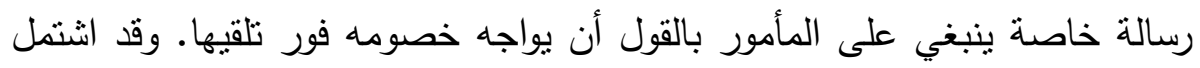

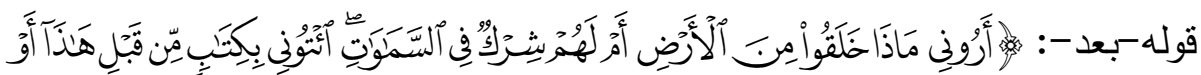

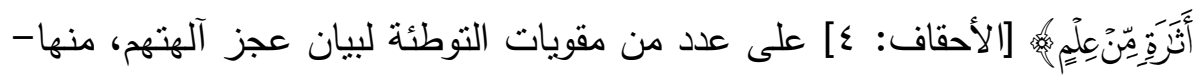

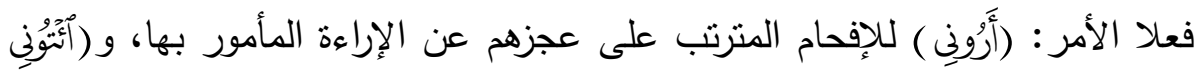

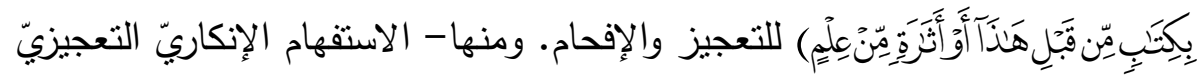

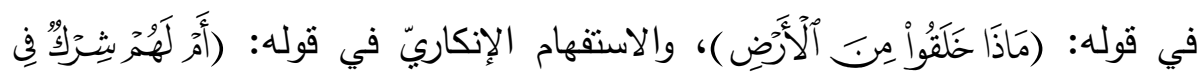
آلمَّمَوَتِِ) المتضمن التوبيخ والإفحام.

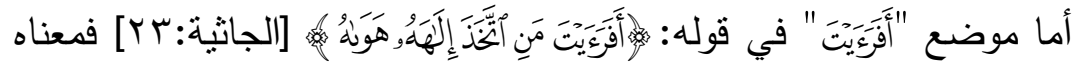
الحرفيّ الاستفهام عن اتخاذ الكافر إلهه هواه. وقوته الإنجازية هي إثارة النشاط الذهنيّ حول الكافر الخاضع لهواه، المعطّل حواسه، وإثارة الذهن حوله، والتوطئة

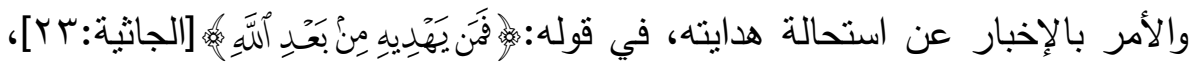

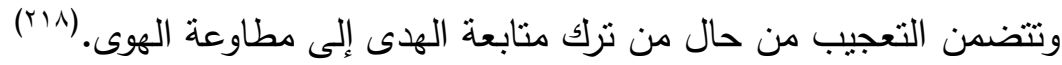

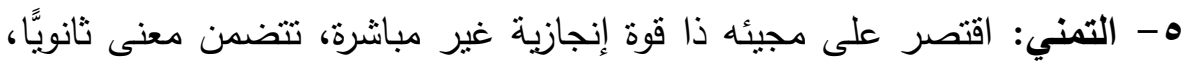
واختصاصه بالدليل الإنجازيّ " هَّْ" داخلة على جملة اسمية في موضعين، الأول-

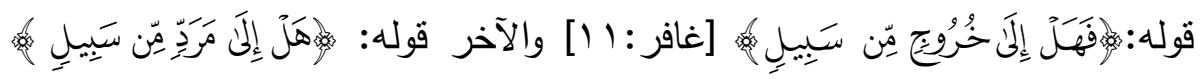
[الشورى:؟§] ومعناهما الحرفيّ الاستفهام عن الخروج من النار. والأول قوته

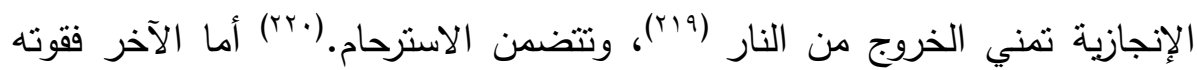

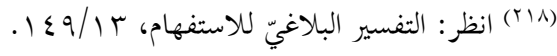

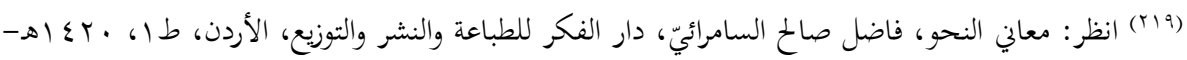

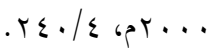

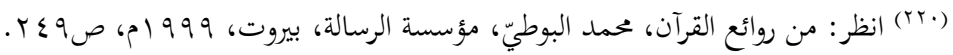


الإنجازية تمني العودة إلى الحياة(rr)، وتتضمن التحسر والتتدم على ما فات.(rrr) واستعمال (هل)، والعدول عن (ليت) يقوي إنجاز التمني؛ إذ في استعمال (هل) إبراز المتمني المستحيل وإظهاره في صورة المكن القريب من الحصول الذي لا جزم بانتفائه، لكمال العناية به والثوق إليه.(r) צ- التعجيب: وقد اقتصر على مجيئه ذا قوة إنجازية غير مباشرة، تتضمن معنى

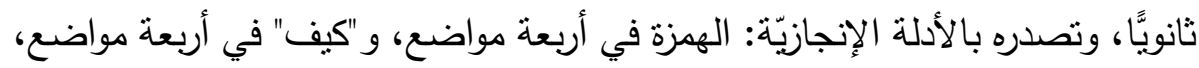

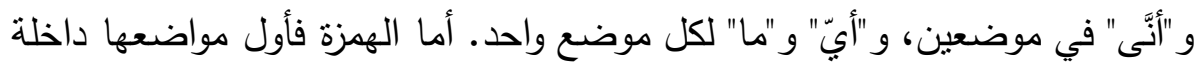

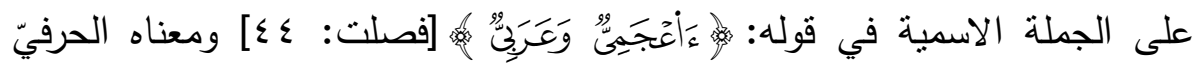
الاستفهام عن لغة القرآن والرسول. وقوته الإنجازية التعجب من التتافر بين الخطاب

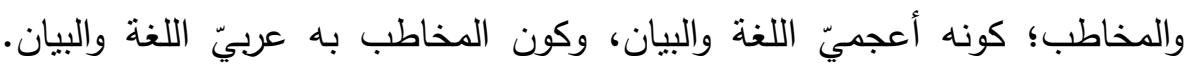

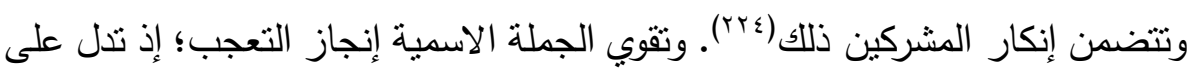
استمراره ودوامه. وثاني المواضع للهمزة الداخلة على الجملة الفعلية المضارعية المنفية

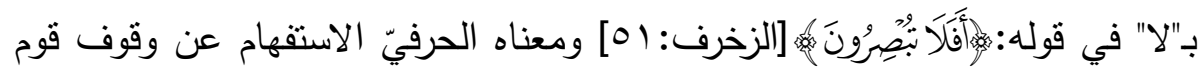
فرعون على عظمة ملكه مصر • وقوته الإتجازية التعجب من عدم وقوفهم. وتتضمن لوناه

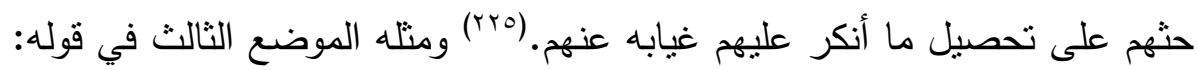

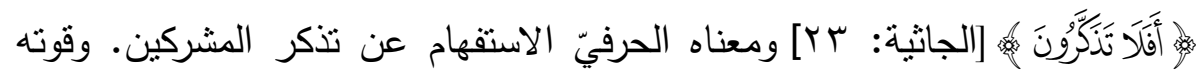

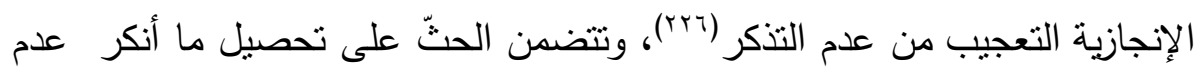
تحصيله.(YrV) أما الموضع الربابع فناءت الهمزة داخلة على الجملة الفعلية

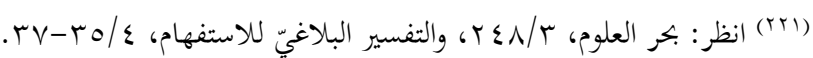

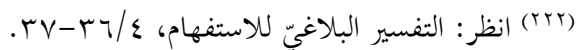

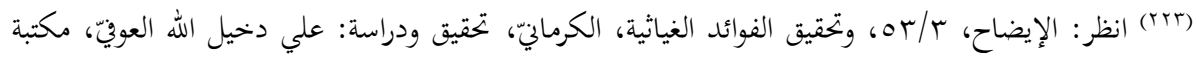

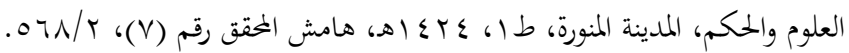

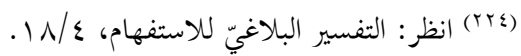

$$
\begin{aligned}
& \text { (T) }
\end{aligned}
$$

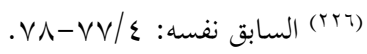

$$
\begin{aligned}
& \text { VN/ \& السابق نفسه: (TYV) }
\end{aligned}
$$




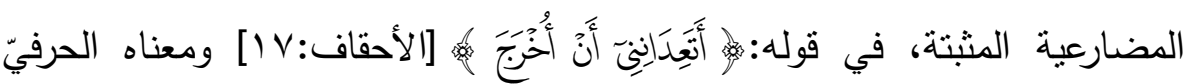

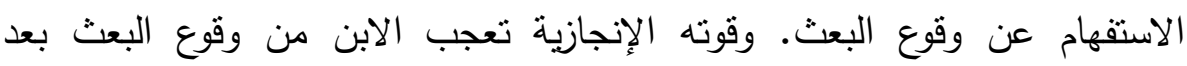

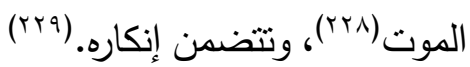
وجئ بالمضارع (تُبْرِرونَ) و و(تَذَكَّونَ) لتقوية إنجاز التعجب؛ إذ دلالة الاسم

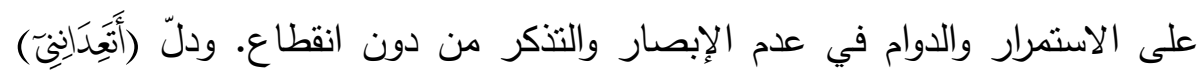

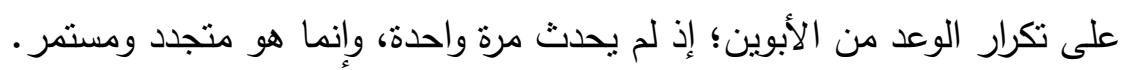
ومواضع "كيف" أربعة، وهي قوله:

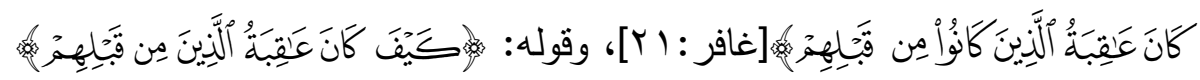

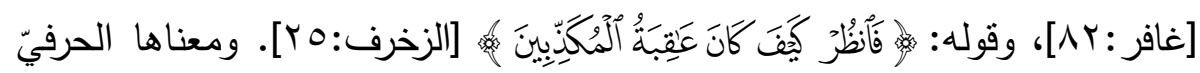
الاستفهام عن عاقبة المكذبين والمجادلين في آيات الله من الأمم السابقة، وقوتها

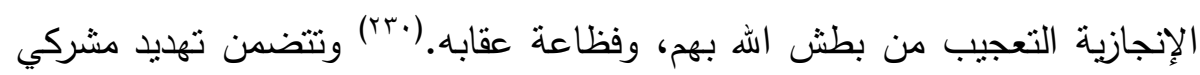

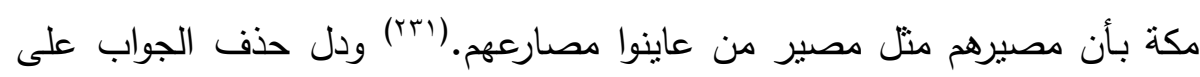

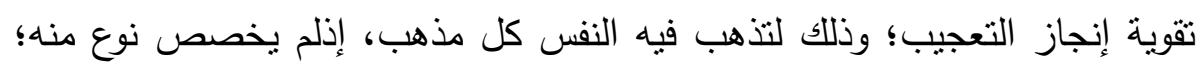
لنقف على منتهاه. وأما موضعا "أنىى" فالأول - قوله: الاستفهام عن انصراف المشركين عن آيات الله الموجبة الإيمان بها. وقوته الإنجازية

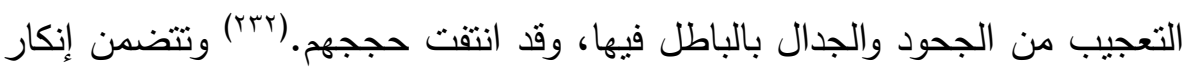
انصرافه عن آيات اله.(rrr) ويقوي إنجاز التعجيب ويؤكده السياق السابق واللاحق

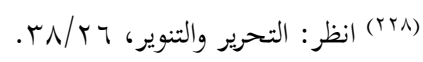

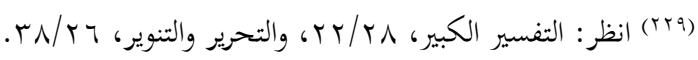

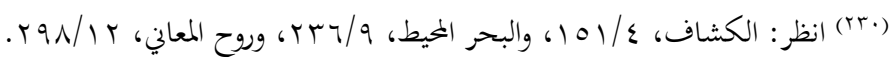

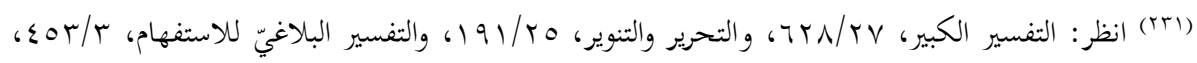
\& $\vee$ Vo/rg ؛

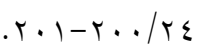

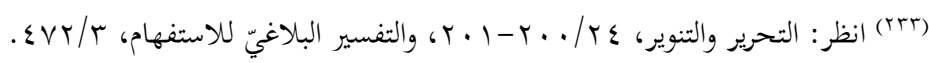
\&. 0 
للآية، أما السابق فقد ذكر فيه مراحل خلق الإنسان، واختصاص الله -عزّ وجلّ--

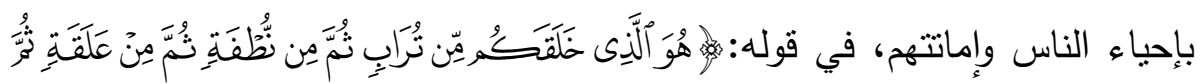

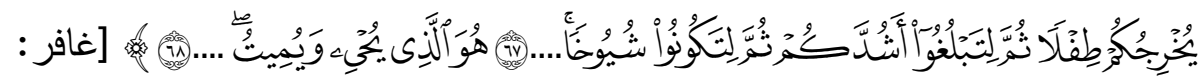

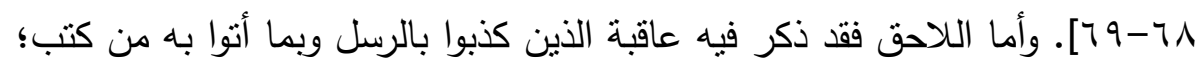

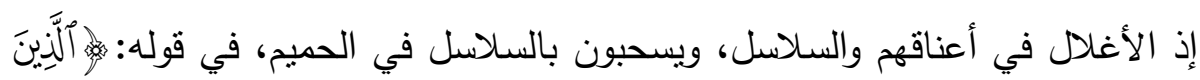

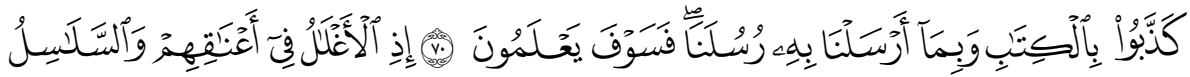

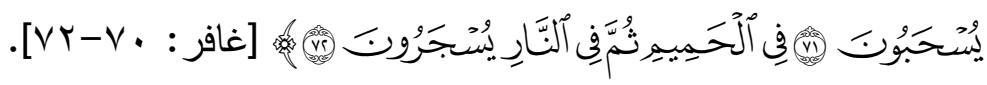
والثاني- قوله: عن اعتبار المشركين وتذكرهم، مع تكذيبهم النبيّ. وقوته الإنجازية التعجيب من أن أن

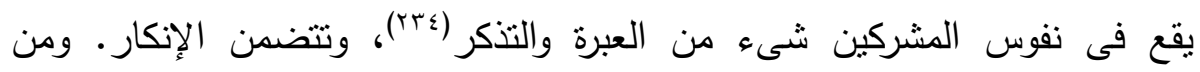

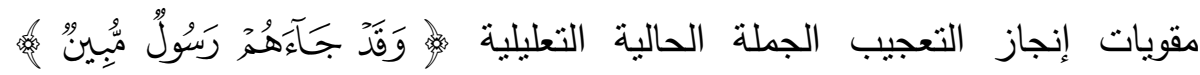

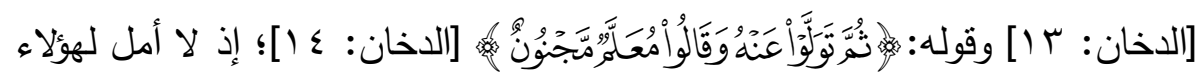

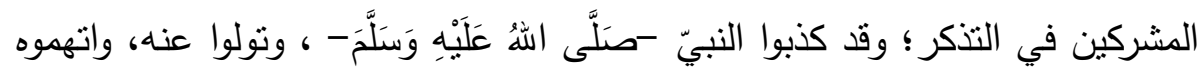
بأنه مجنون، قد علم هذا الكلام.

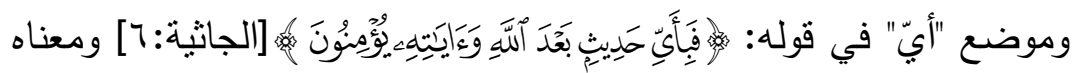
الحرفيّ الاستقهام عن موقف المشركين من الإيمان بآيات الله. وقوته الإنجازية

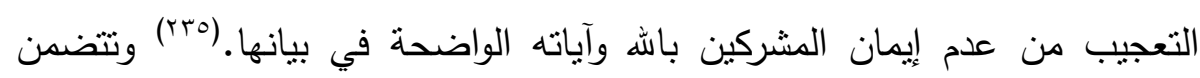

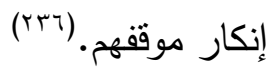

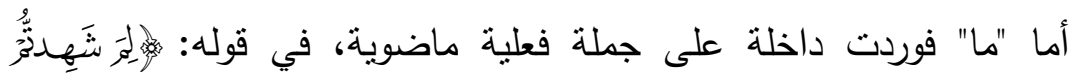

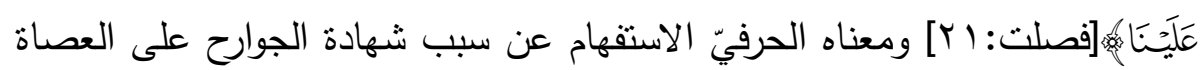
يوم القيامة. وقوته الإنجازية التعجب من شهادة الجوارح على الصحابها

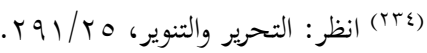

$$
\begin{aligned}
& \text { (ro) }
\end{aligned}
$$

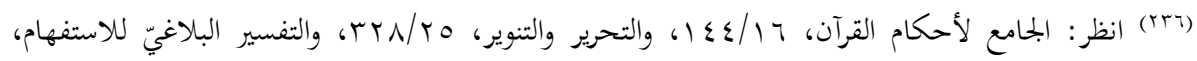




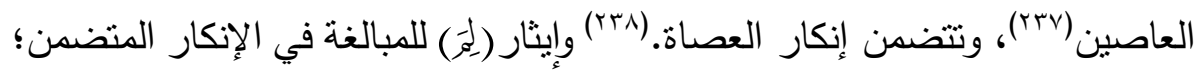
لأنها لنفي السبب وإنكاره، ونفي السبب يستلزم نفي المسبب؛ أي ليس لشهادة الجلود أسباب.

V - الاستحالة: وقد اقتصر على مجيئها ذات قوة إنجازية غير مباشرة، تتضمن معنى

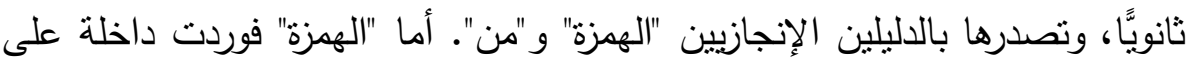

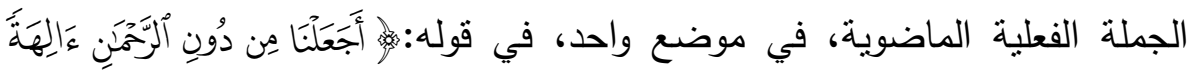

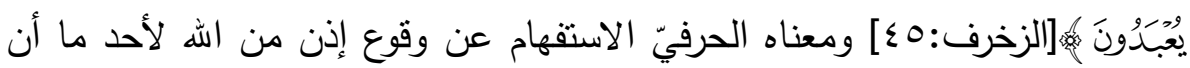

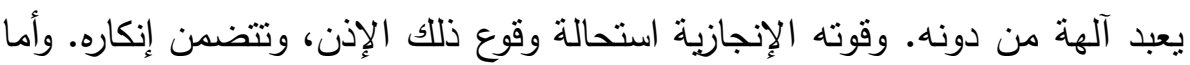

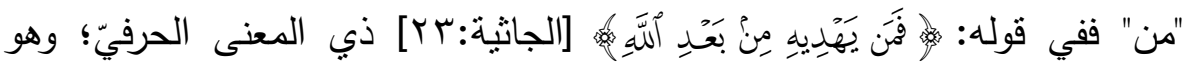

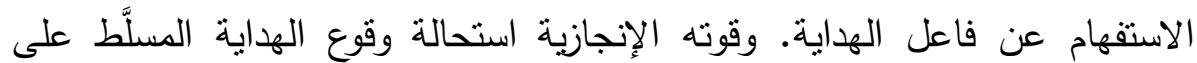

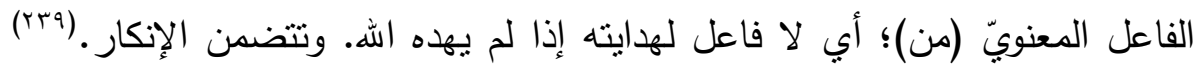
وإيثار المضارع في (يُجبَدُونَ) و (يَهُدِيهِ) يقوي إنجاز الإستحالة؛ إذ يشمل الأوقات كلها. ويقوي قوله:

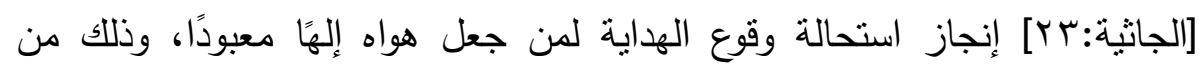

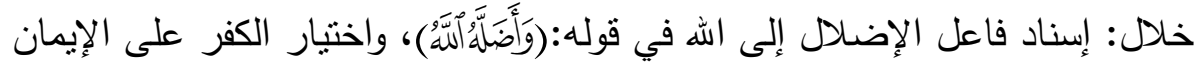
عن علم منه في قوله:(عَلَّ بعلِِِ)، ومنع وصول الهدى إلى القلب، ومنع السمع من

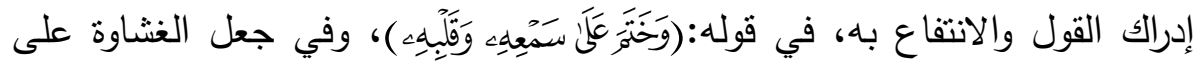

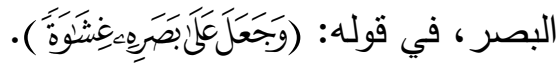

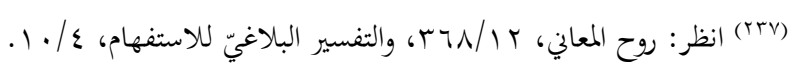

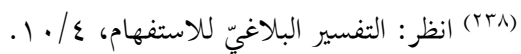

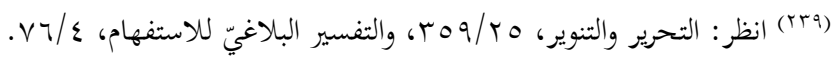




\section{الخاتمة (نتائج البحث)}

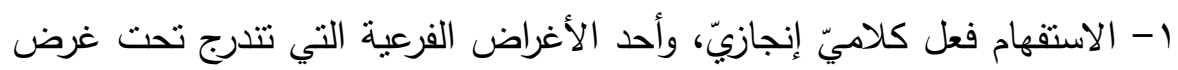
من الأغراض الإنجازية الكبرى، وهي: أفعال الإيضاح عند "أوستن"، أو أفعال التوجيه

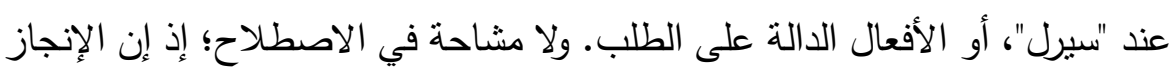

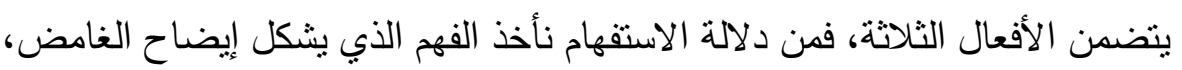

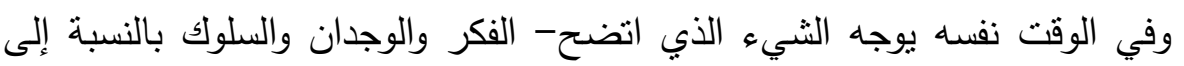
الذات والآخر، أما الأفعال الدالة على الطلب فيعتمد عليها تحت مظلة التأصيل العربيّ؛ إذ يطلب بها المتكلم من المخاطب الجواب عن سؤال يجهله.

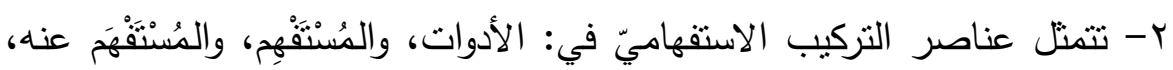
والمخاطب بالاستقهام. أما الأدوات فتمثل الأدلة الإنجازية، وقد جاءت الادرات، منتوعة في

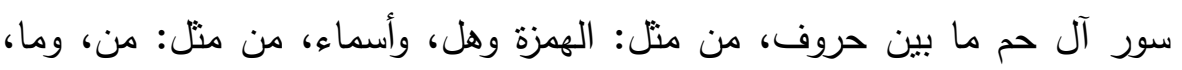

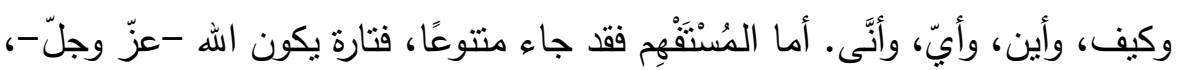

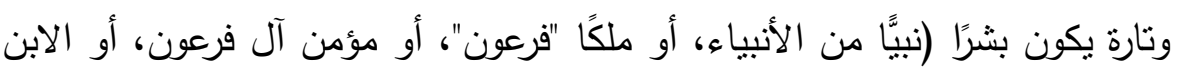

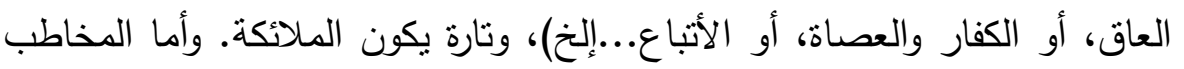

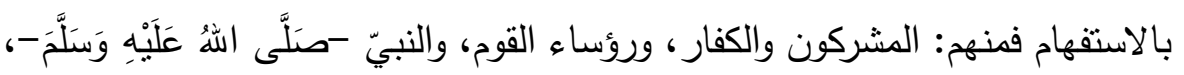
وأهل النار، وملائكة العذاب...إلخ.

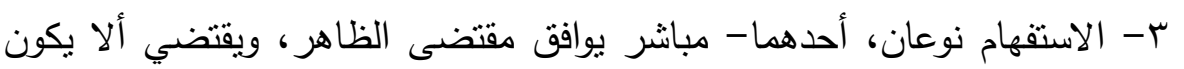

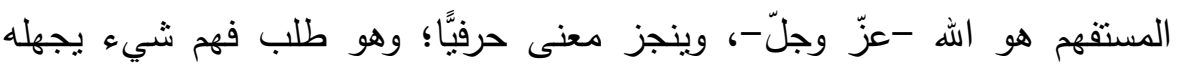

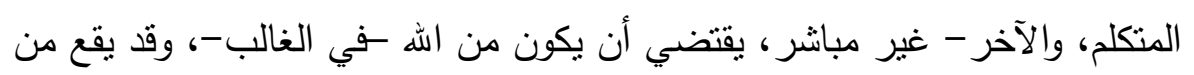
البشر والملائكة وغيرهما، ويخالف مقتضى الظاهر ، إلى معانٍ تداولية.

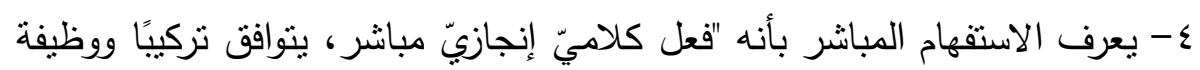

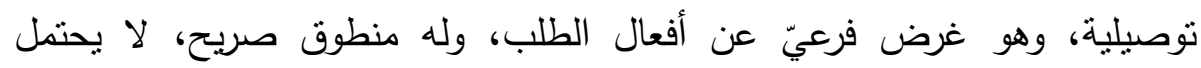
التأويل، ويقصد به إنجاز المعنى الحرفيّ الذي يلازمه في مختلف السياقات، وهو

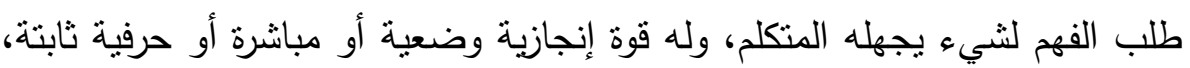


لا تتغير باختلاف السياقات، وهي الجواب عن السؤال، بأداة تمثل الدليل الإنجازيّ

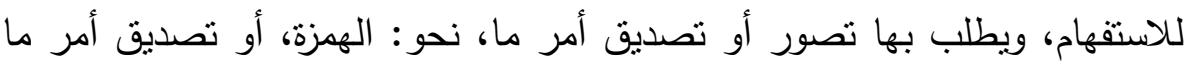

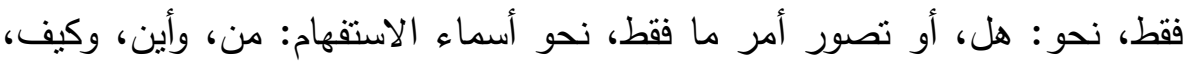

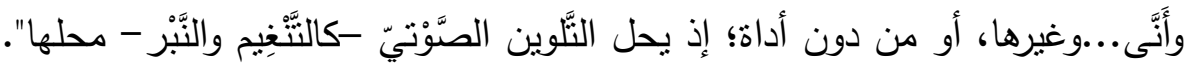

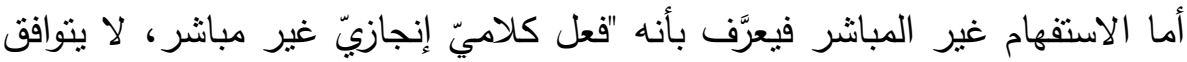
تركيبًا ووظيفة توصيلية؛ إذ ندل هيئته التركيبية على معنى لا يقصده المتكلم، فيخرج

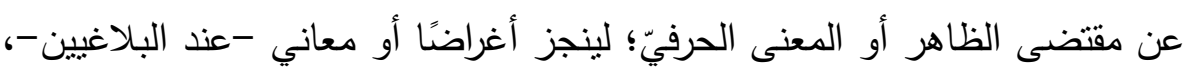

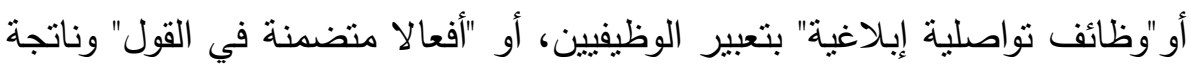

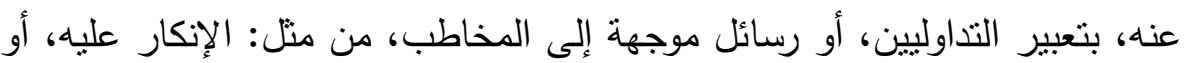
تقريره، أو توبيخه وتقريعه، تتتوع تبعًا لاختلاف السياقات، ومصدرة بالداليل الإنجازيّ،

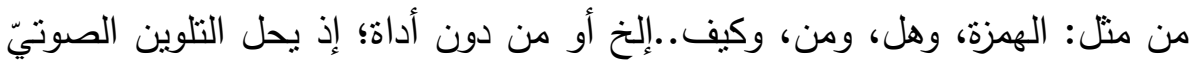

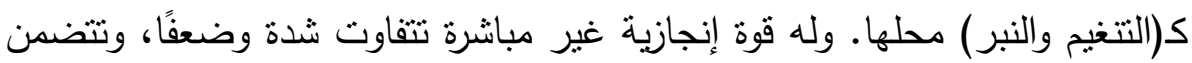

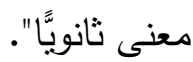
0- للاستفهام المباشر محددات أو ضوابط يجب توافرها، من أهمها: عنصر الزمان،

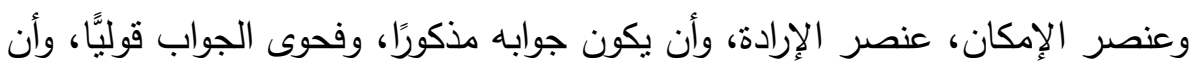

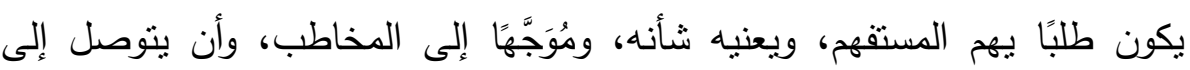
غرضه الإنجازيّ الحرفيّ من نركيب العبارة نفسه، وأنه ذو قوة إنجازية مباشرة أو ولئه وضعية.

7- للاستقهام غير المباشر محددات أو ضوابط يجب توافرها، منها: السياق، وقصد المتكلم، وقدرة الدُخَاطَب على فهم قصد السائل، وحذف الجواب ، وألا يكون الاستقهام

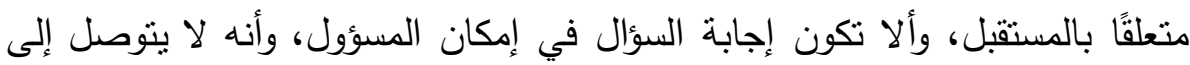
غرضه الإنجازيّ من نركيب العبارة، ويجوز أن يلغى، ويبتوع وفق السياقات المختلفة المانه

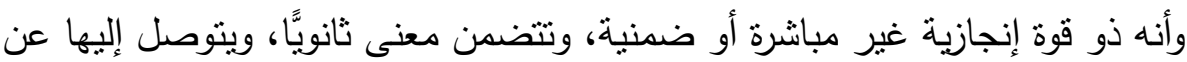
طريق عمليات الاستدلال العقليّ، وتضمنه الفعل الإنجازيّ المباشر؛ لكونه محوّلا

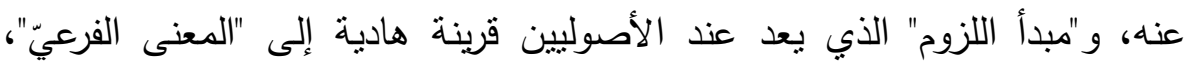
وصدوره عن الله -عزّ وجلّ-. 
V للاستقهام قوتان إنجازيتان، إحداهما- مباشرة أو وضعية، إن كان الاستقهام

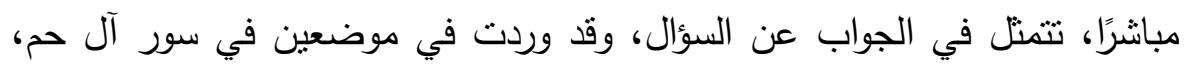

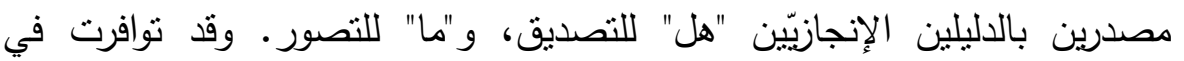
الموضعين شروط إجراء الاستفهام على الأصل، وطابقت قوتهما الإنجازية مراد

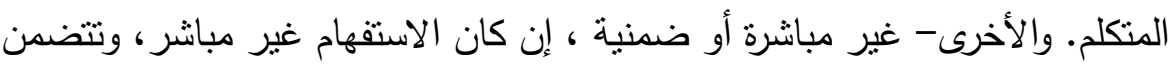

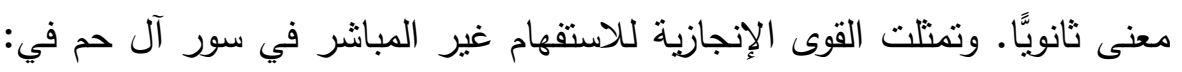

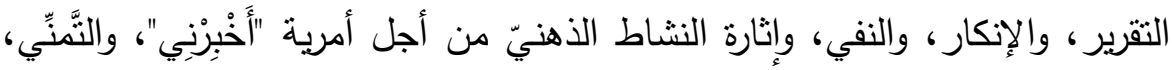

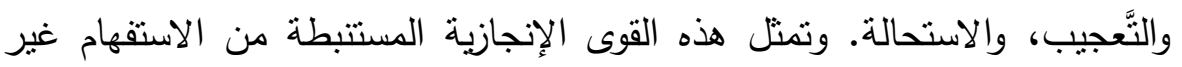
المباشر في سور آل حم بواعث إضافية أساسية، خلافًا لما ذهب إليه سيرل حين رأى الإنيه

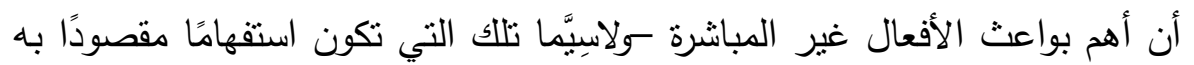
الطلب- هو التأدب في الحديث. والاستقهام -بهذه الصورة- فعل كلاميّ إنجازيّ غير مباشر؛ إذ معناه الحرفيّ غير مقصود، وتخالف قوته الإنجازية الحرفية قوته الإنجازية غير الحرفية التي هي مراد المتكلم، وهي قوى إنجازية غير مباشرة تحكمها

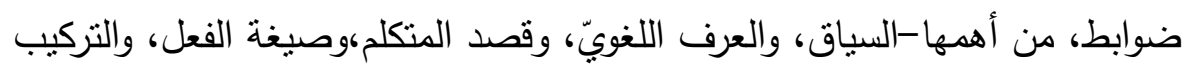
النحويّ، وقدرة المخاطب على الاستدلال، ومصاحبات المنطوق...إلخ. V - يعد التركيب الاستفهاميّ بصورته المباشرة أقوى إنجازًا من التركيب الاستقهاميّ في صورته غير المباشرة؛ إذ إنه -في صورته المباشرة- وسيلة من وسائل نقوية الإنجاز الذي يضيف قوة إلى قوة المنطوق الإنجازية؛ لصيغته ذات الدلالة الصريحة المباشرة،

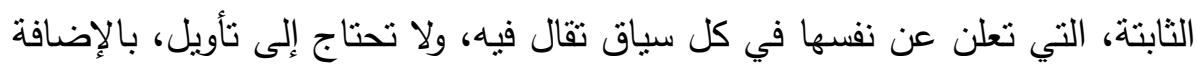

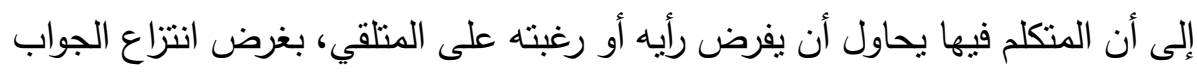

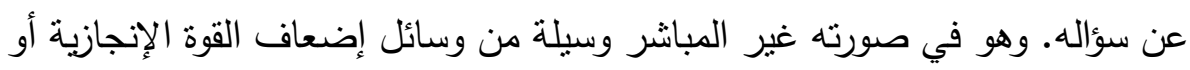

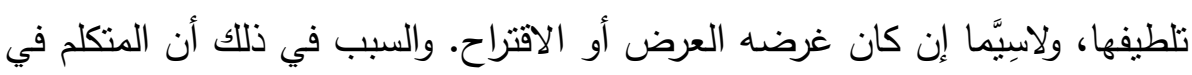

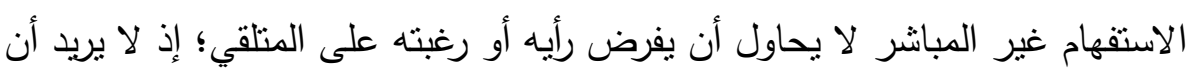

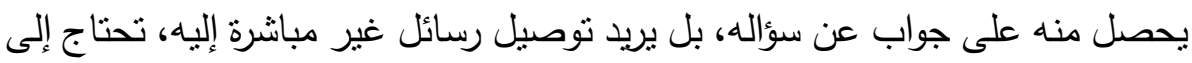

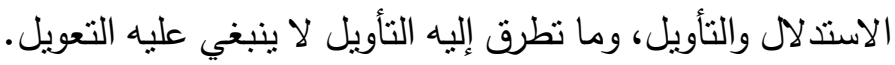


1- تكثف الدراسة التطبيقية للقوة الإنجازية للاستفهام في سور آل حم- عن تفاوت

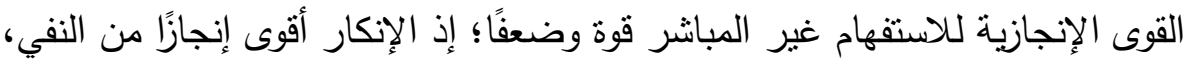

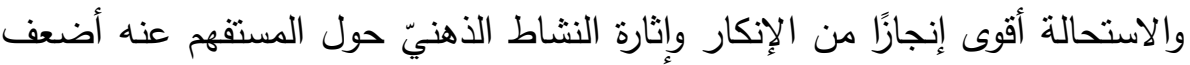

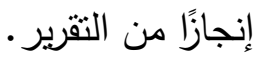
9- يعد الإنكار هو القوة الإنجازية المهيمنة على القوى الإنجازية الأخرى؛ إذ ورد في

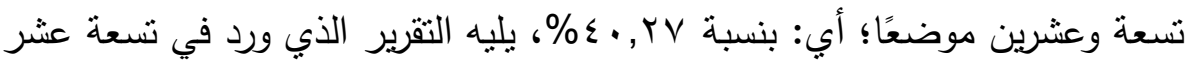

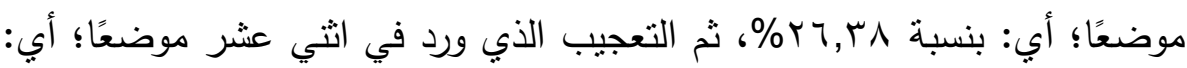
بنسبة 77,7 (7\%، ثم إثارة النشاط الذهنيّ التي وردت في أربعة مواضع؛ أي: بنسبة

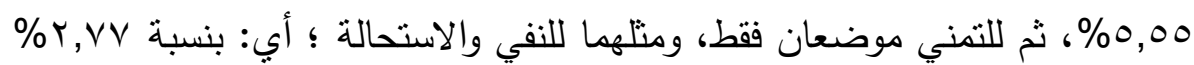

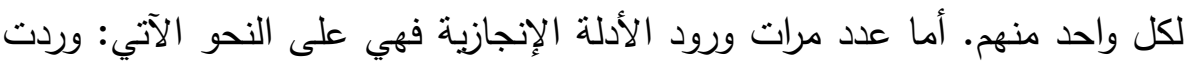

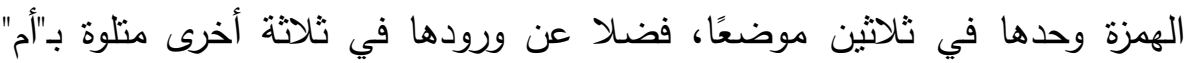

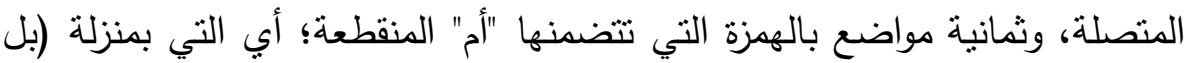

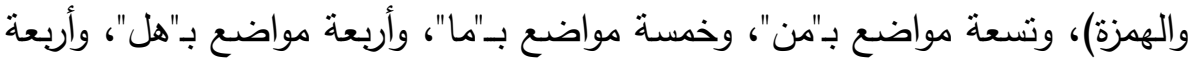

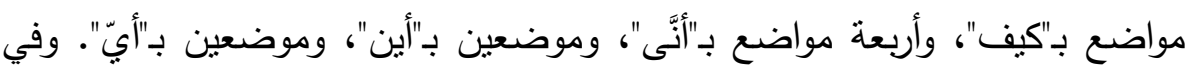

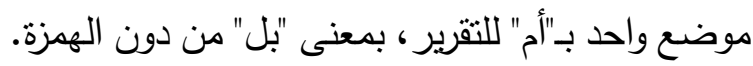
• 1- نتج عن الاستقهام غير المباشر في سور آل حم قوى إنجازية منضادة، نحو :

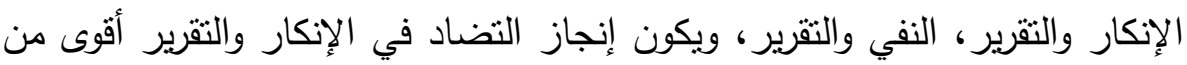
إنجاز التضاد في النفي والتقرير • ومن ثم يمكن أن نستتنج أن القوة الإنجازية تكون في التذرج شدةً وضعفًا، كما تكون في المعاني المتضادة.

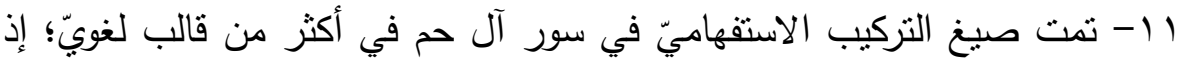

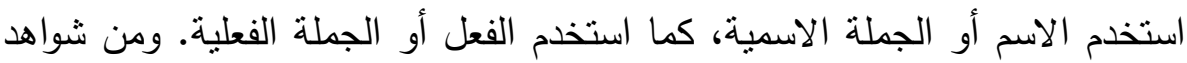

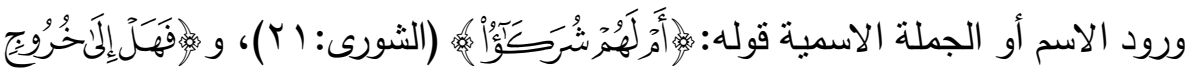

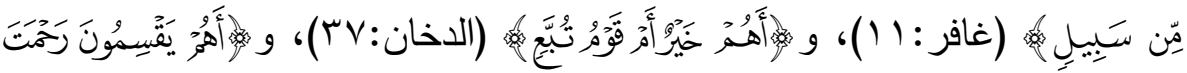

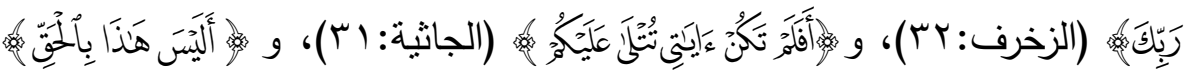

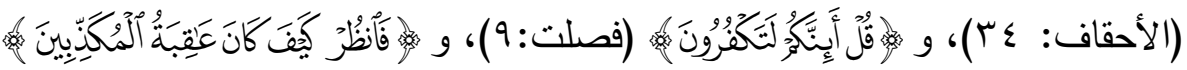




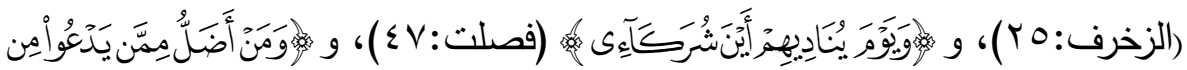

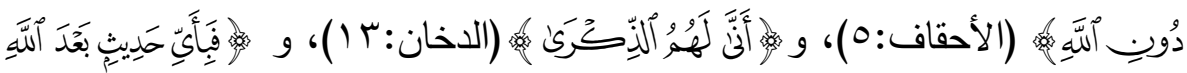

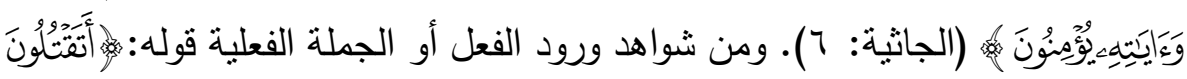

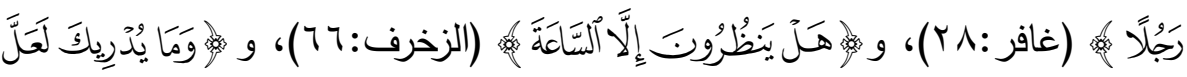

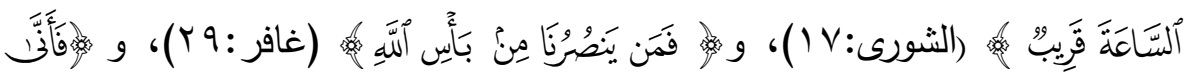

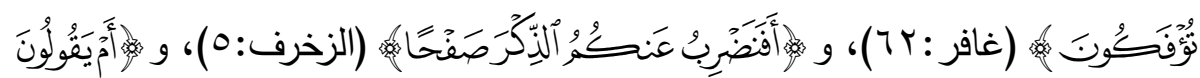

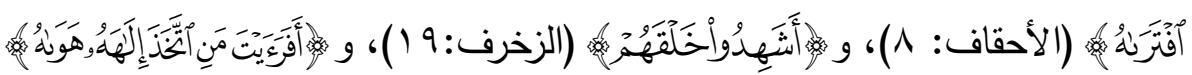

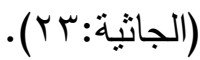

r ا - في أداء النفي والإنكار، والتقرير، والتمني، والتعجيب، وإثارة النشاط الذهنيّ، والاستحالة- عن طريق الاستفهام معانٍ لا تؤدى في غيره؛ إذ الظاهر أن معنى النفي المستفاد في سور آل حم من (الهمزة) و (ما) لا يطابق النفي بحرف النفي، بل المعنى مختلف من جهنين، الأولى - أن النفي بـ (الهمزة) و (ما) ليس نفيًا محضًا، بل إنه استفهام أثنرب معنى النفي، وقد جاء متضمنًا معنى التوبيخ مع الهمزة، والتهديد مع (ما)، وهذا ما لا يؤديه النفي المحض. والجهة الأخرى- أن المقصود من النفي عن طريق الاستفهام هو إثراك المخاطب في الأمر؛ لأثك بأسلوب الاستفهام نترقب منه جوابًا، وليس كذللك في النفي الصريح؛ إذ المقصود بالنفي الصريح إقرار من المخبر .كما يتعلق أداء النفي عن طريق الاستقهام بالدلالة على ثقة المتكلم بنفسه فيما قاله. ومثله الإنكار الذي تضمن: التوبيخ، والتجهيل، والتقريع، والتهكم، والتعجيب، والتهديد بالهمزة، والنصح ، والوعيد بـ"من". أما التقرير عن طريق الاستفهام ففيه تحفيز لإيجابية السامع؛ إذ يجعل ذهنه يبحث عن إجابات فلا يجد، فينقرر المعنى في ذهنه فضل تقرر • وكذلك تضمن التقرير : الرمي بالغفلة، والإلزام بالحجة، والتوبيخ، والتعجيب، والتكبر، والتهكم بالهمزة، والإلزام بالحجة ب"من"....إلخ. ولعل في التَّنّي بـ(هل) والعدول عن (ليت) أداء لوظيفة تواصلية؛ وهي إبراز المتمني المستحيل وإظهاره في صورة الممكن القريب الحصول الذي لا 
جزم بانتفائه؛ لكمال العناية به والثوق إليه. وتضمن التمني ب"هل" الاسترحام،

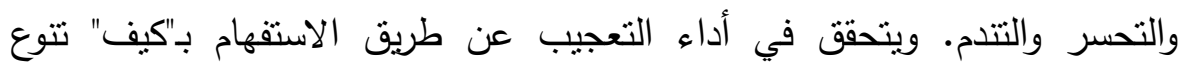
العذاب وتفاوته، الذي تذهب فيه النفس كل مذهب، ولا يتحقق بالتعجب الصريح. وقد تضمن التهديد مع كيف، والإنكار، والحث مع الهمزة، والإنكار مع "أنَّى" بـ" و "أيّ".وفي إثارة النشاط الذهنيّ حول المستقهم عنه- عن طريق الاستقهام بالهمزة المتلوة بـ"رأى"- ما ليس في غيره من الأساليب الخبرية، وكأن المستفهم يقول للسامع: اذهب فانظر بعينك الباصرة، وشكّل صورة ذهنية للمستقهم عنه بعين قلبك، ثم أخبرني بما وصلت إليه، أليس هذا الذي انتهيت إليه مطابقًا لما أقوله، ومقررًا له. وقد تضمن التتبيه، والتقرير، والتعجيب بالهمزة. وقد تضمنت الاستحالة الإنكار بالهمزة و"من". فضلا عن أن في إيراد هذه الدلالات الإبلاغية بأسلوب الاستفهام- نشويقًا وإثارة للتفكير؛ بغية الاهتداء إلى معرفة وجه الصواب، فالاستفهام لا يجهر بمثل هذه الدلالات الخفية، بل يثير العقل الواعي؛ حتى يدرك المقاصد الإلهية، والوظائف التواصلية التي تتضنهها. rا- تميز الاستفهام في سور "آل حم" خاصة، وفي القرآن عامة- باستعمال غير المباشر أكثر من المباشر؛ أب بالميل إلى المقاصد غير المباشرة في التواصل أكثر من المباشرة؛ إذ جاء الاستفهام المباشر في "سور آل حم" في موضعين بـ"هل"، و "ما"،

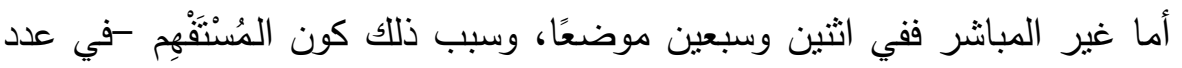
غير قليل من شواهده في سور آل حم- هو الله -عزّ وجلّ-، وهو منزه عن طلب

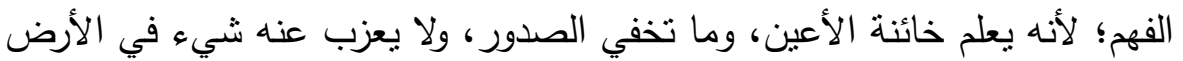
ولا في السماء، وأيضًا لتحريك آلة الاستدلال العقليّ التي يمكن أن تفضي إلى تعديل أفكار المخاطبين، وتغيير معتقداتهم. ع ا - لتقوية الإنجاز في الاستفهام غير المباشر في سور آل حم وسائل لغوية، أهمها: السياق أو مصاحبات المنطوق، والتركيب النحويّ ونتوع التعبير به تعريفًا وتتكيرًا،

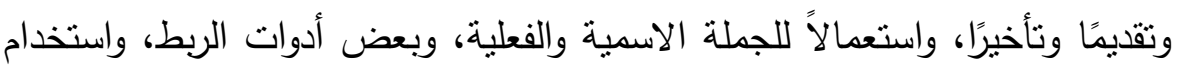


د. حسين إبراهيم محمد

شبه الجملة، وصيغة الفعل، وبعض الأدوات، مثل: أدوات الاستقهام، والتوكيد...إلخ. واستخدام بعض الأساليب، مثل: التوكيد، والحصر ، والأمر ...إلخ. 


\section{المصادر والمراجع}

$$
\text { أولا- العربية }
$$

أحمد حسام قاسم: تحويلات الطلب ومحددات الدلالة، دار النصر للنشر والتوزيع،

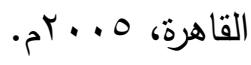

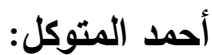

1- آفاق جديدة في نظرية النحو الوظيفيّ، منشورات كلية الآداب والعلوم الإنسانية، سلسلة بحوث ودراسات رقم (0)، دار الهلال العربية الرباط، ب99 ام. r- دراسات في نحو اللغة العربية الوظيفيّ، أحمد المتوكل، دار الثقافة، الدار

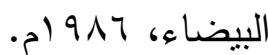
ب- المنحى الوظيفيّ في الفكر اللغويّ العربيّ-الأصول والامتداد، أحمد المتوكل، دار

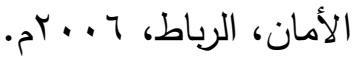
أحمد محمد الإدريسيّ: تداوليات الخطاب ولسانيات السكاكيّ، رسالة دكتوراة، جامعة القاهرة، كلية الآداب، قسم اللغة العربية، وA1 ام. الألوسيّ (شهاب الدين محمود بن عبد الله الحسيني، ت • r اهـ): روح المعاني في تفسير القرآن العظيم والسبع المثناني"، تحقيق: علي عبد الباري عطية، دار الكتب العلمية، بيروت، ط ا، 0 إع اهـ. البخاريّ (أبو عبد الله محمد بن إسماعيل- تـهـهـ): صحيح البخاري، تحقيق:

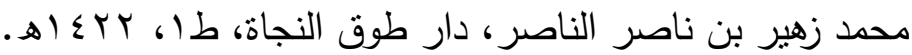
البيضاويّ (نصر الدين أبو سعيد عبد الله بن عمر - ت 710هـ): "أنوار التنزيل وأسرار التأويل"، تحقيق محمد عبد

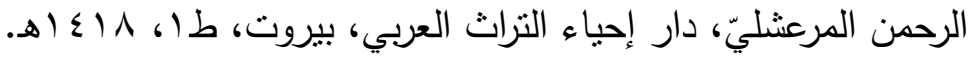
تمام حسان: اللغة العربية معناها ومبناها، دار الثقافة، الدار البيضاء، المغرب، 
الثعالبيّ (أبو منصور عبد الملك بن محمد بن إسماعيل-ت 9 ؟ـه): فقه اللغة وسر

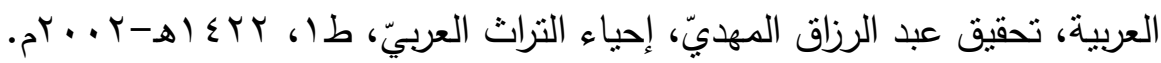
الجرجانيّ (أبو بكر عبد القاهر بن عبد الرحمن- ت (V§هـ): دلائل الإعجاز، تحقيق

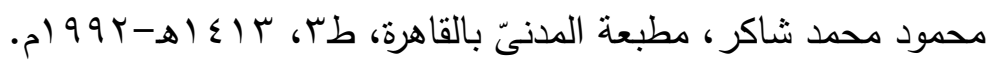

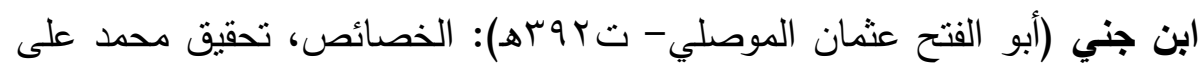

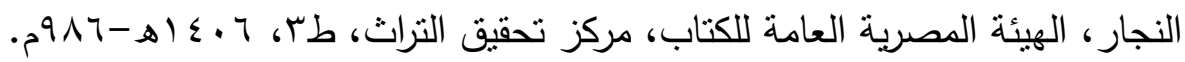

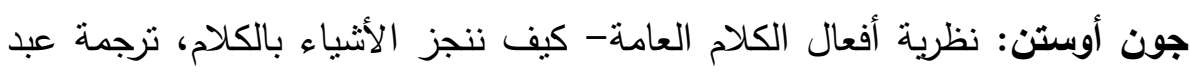

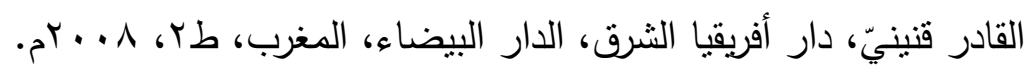
أبو حيان (أثير الدين أبو عبد الله محمد بن يوسف بن علي الأندلسيّ- ته Vهـ): البحر المحيط، تحقيق صدقي جميل، دار الفكر، بيروت، • بـ اله.

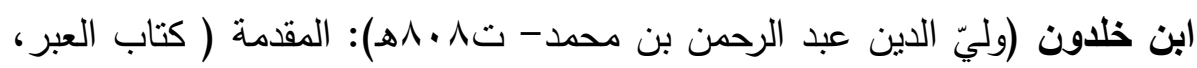
وديوان المبتدأ والخبر في أيام العرب والعجم والبربر ، ومن عاصرهم من ذوبي السبن السطان

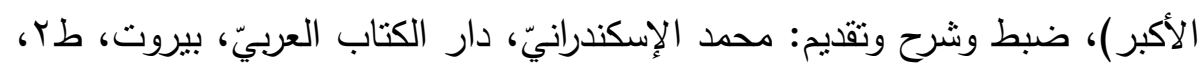
. $) 991$ الرازيّ (فخر الدين محمد بن عمر - ت7 • 7هـ): التفسير الكبير، دار إحياء التراث

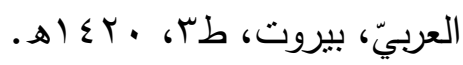
رضيّ الدين الإستراباذيّ: شرح الكافية، تصحيح وتعليق يوسف حسن عمر، جامعة

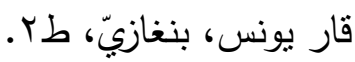
الزجاج (أبو إسحاق إبراهيم بن السَّري بن سهل- ت المآهـ): معاني القرآن وإعرابه،

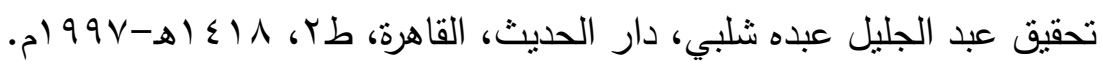
الزركشيّ (بدر الدين محمد بن عبد الله- ت \&9 9ه): البرهان فى علوم القرآن، تحقيق

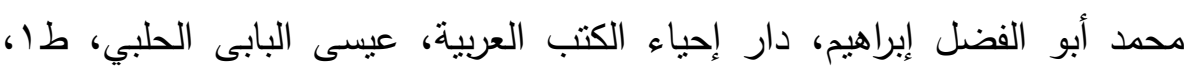
.5) $190 \mathrm{~V}-\mathrm{A} / \mathrm{MVT}$ 
الزمخشـريّ (جار الله أبو القاسم محمود بن عمر - تمرهـهـ): الكثــاف عن حقائق

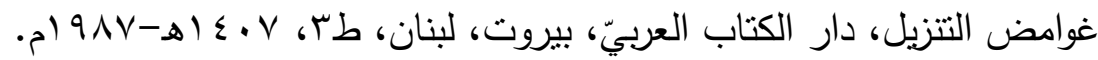

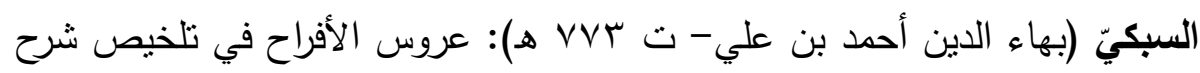

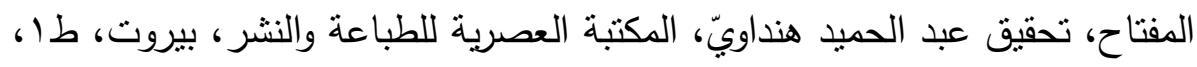
r. ستانلي فش: "هل يوجد نص في هذا الفصل"، ترجمة: أحمد الثيميّ، ومراجعة:

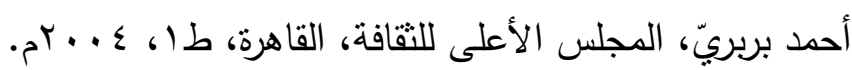
أبو السعود (محمد بن محمد العماديّ-- ت190هـ): إرشاد العقل السليم إلى مزايا الكتاب الكريم، دار إحياء التراث العربي، بيروت. السكاكيّ (أبو يعقوب يوسف بن محمد السكاكيّكت بrTهـ): مفتاح العلوم، تحقيق:

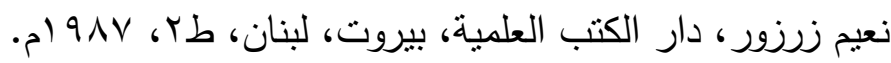

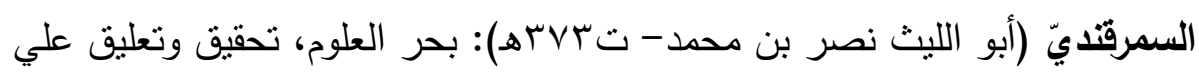
محمد معوض، وعادل أحمد عبد الموجود، وزكريا عبد المجيد النوتي، دار الكتب لهب لهن

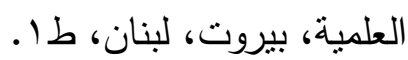
السهيليّ (أبو القاسم عبد الرحمن بن عبد الله بن أحمد- ت المهـ) ): نتائج الفكر في

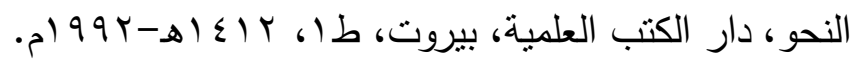
سيبويه (أبو بشر عمرو بن عثمان بن قنبر الحارثي، ت.11 (هـ): الكتاب، تحقيق

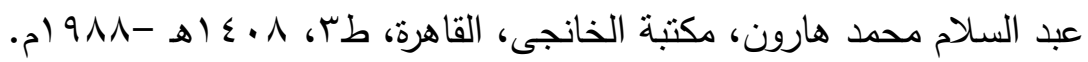
السيوطيّ (جلال الدين عبد الرحمن بن أبي بكر - ت (1) أهـ):

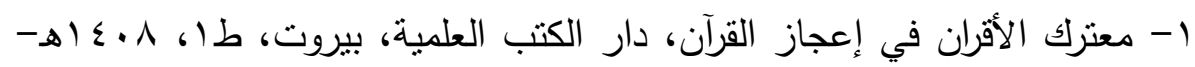
.01911 ץ- همع الهوامع في شرح جمع الجوامع، تحقيق: عبد الحميد هنداويّ، المكتبة

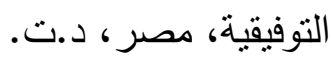


الشاطبيّ (إبراهيم بن موسى بن محمد- ت . V9هـ) الموافقات في أصول الشريعة، تحقيق عبد الله دراز، دار المعرفة، بيروت، ؟9 99 ام. ابن الشجريّ (ضياء الدين أبو السعادات هبة الله بن علي بن حمزة- ت ت ـ0هـ):

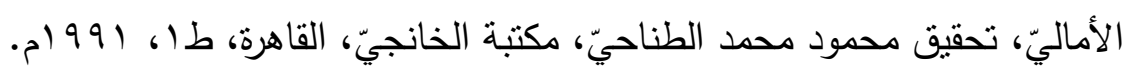

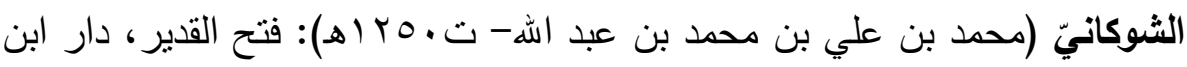

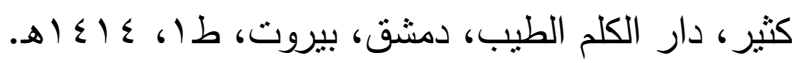

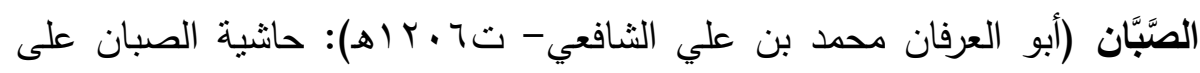

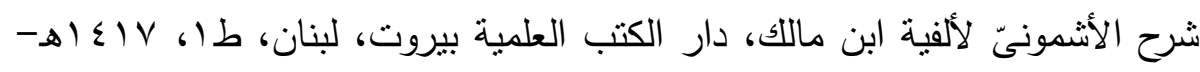
. $99 \mathrm{~V}$ صلاح إسماعيل عبد الدق:التحليل اللغويّ عند مدرسة أكسفورد،دار التتوير للطباعة والنشر كبيروت،ط أ، سو 99 ام. صلاح الدين صالح حسنين: الدلالة والنحو، مكتبة الآداب، القاهرة، طا، ه م. . بم. صلاح فضل: بلاغة الخطاب وعلم النص، الثركة المصرية العالمية لونجمان،

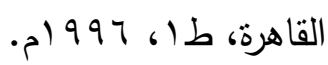
الطبريّ (أبو جعفر محمد بن جرير كت • آسه): جامع البيان في تأويل القرآن، تحقيق

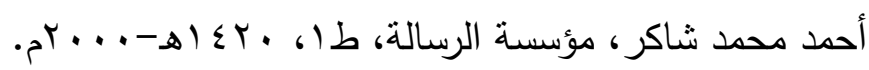

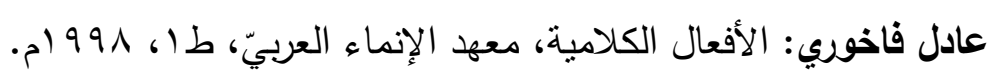

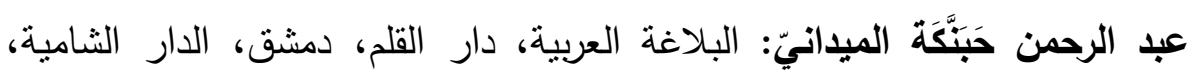

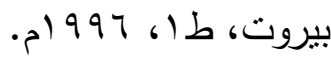
أبو عبيدة (معدر بن المثنى-ت +r. هـ): مجاز القرآن، تحقيق محمد فواد سزكين،

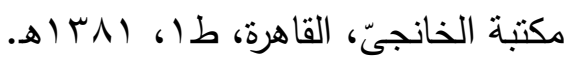
الغزناطيّ (أبو جعفر أحمد بن إبراهيم بن الزبير - تم • Vهـ): ملاك التأويل القاطع

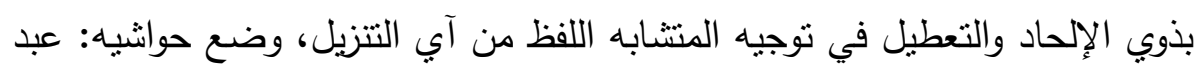

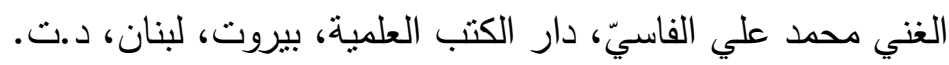


عبد السلام هارون: الأساليب الإنشائية في النحو العربيّ، مكتبة الخانجيّ بمصر، . ) $9 \vee 9$, عبد العظيم المطعنيّ: التقسير البلاغيّ للاستفهام في القرآن الحكيم، مكتبة وهبة،

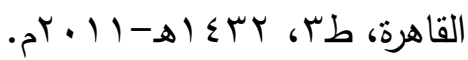
عبد الهادي الشهري:إستراتيجيات الخطاب،مقاربة لغوية تداولية،دار الكتاب الجديد المتحدة،بيروت، ط ا، ع . . ب م. ابن عطية الأندلسيّ (أبو محمد عبد الحق بن غالب- ت تعـهـ): المحرر الوجيز في تفسير الكتاب العزيز، تحقيق عبد السلام عبد الثافيّ محمد، دار الكتب العلمية،

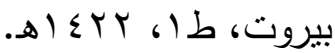

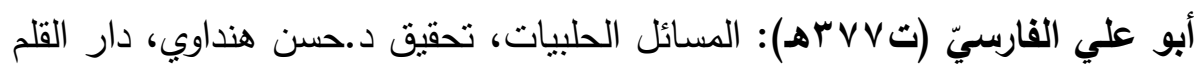
للطباعة والنشر والتوزيع، دمشق، دار المنارة للطباعة والنشر والتوزيع، بيروت، طاء، دهن . $9 \wedge \vee-ه) \leqslant \cdot \vee$ علي محمود الصَّراف: في البراجماتية، الأفعال الإنجازية في العربية المعاصرة-

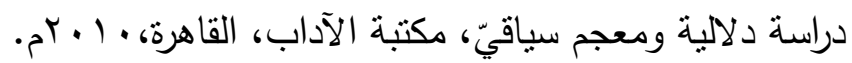

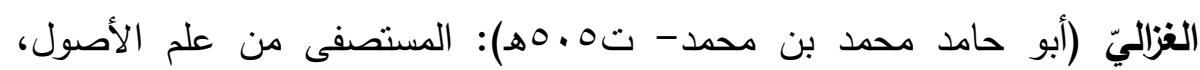
تحقيق محمد عبد السلام عبد الثنافي، دار الكتب العلمية، طا، بو99 ام. الفارابيّ: كتاب الحروف، حققه وقدم له محسن مهدي، دار المشرق، بيروت، ط؟، .p) 99 . ابن فارس (أبو الحسين أحمد بن فارس بن زكرياء- ت 90بهـ): الصاحبيّ في فقه اللغة ومسائلها وسنن العرب في كلامها، منشورات محمد علي بيضون، دار الكتب لئ بن

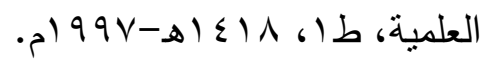
فاضل صالح السامرائيّ: معاني النحو، دار الفكر للطباعة والنشر والتوزيع، الأردن، ط فان ديك: النَّصّ والسياق - استقصاء البحث في الخطاب الدلاليّ والتذاوليّ، ترجمة عبد القادر قنينيّ، الدار البيضاء، دار إفريقيا الشرق، د.ت. 
فضل حسن عباس: البلاغة فنونها وأفنانها-علم المعاني، سلسلة بلاغتتا ولغتتا( ()،

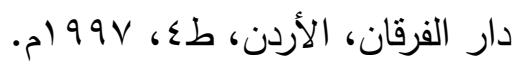

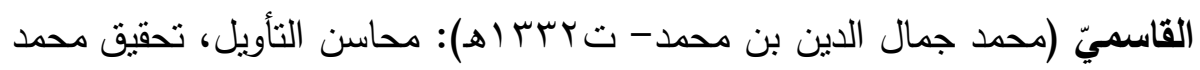

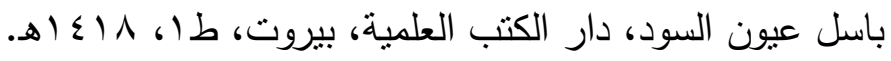

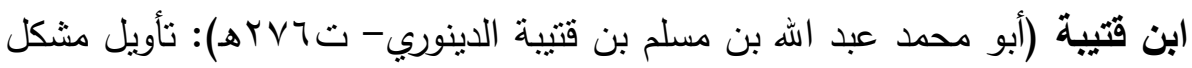
القرآن، تحقيق: أحمد صقر ، المكتبة العلمية، د.ت.

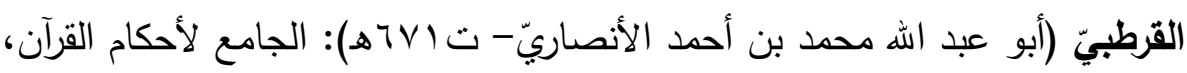

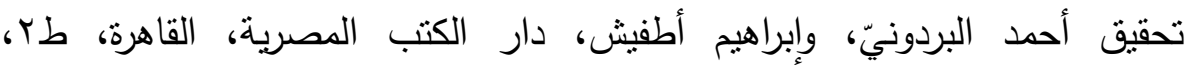
$.0197 \varepsilon-81 T \Lambda \varepsilon$ القزوينيّ (جال الدين محمد بن عبد الرحمن بن عمر - ته مVه): الإيضاح في علوم البلاغة، تحقيق: محمد عبد المنعم خفاجيّ، دار الجيل، بيروت، طس، د.ت.

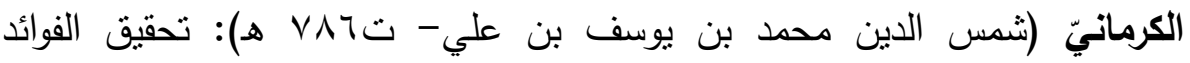
الغياثية، تحقيق ودراسة: علي دخيل الله العوفيّ، مكتبة العلوم والحكم، المدينة

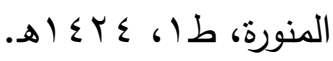

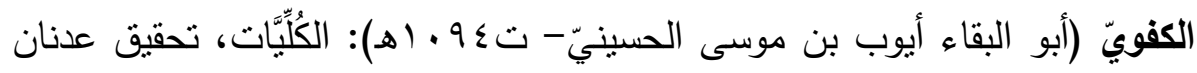

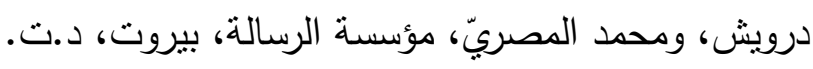

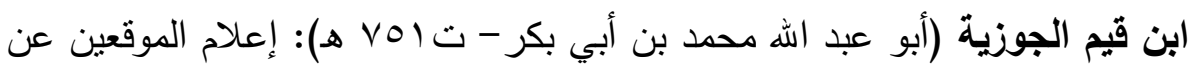

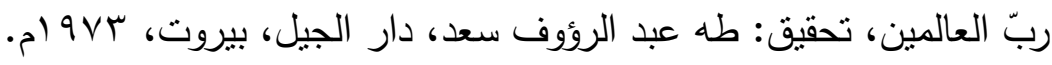

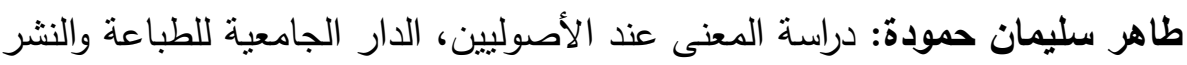

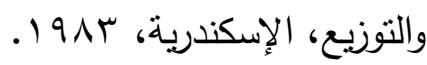
الماتريديّ (أبو منصور محمد بن محمد- ت سTسهـ): تفسير الماتريديّ "تأويلات أهل

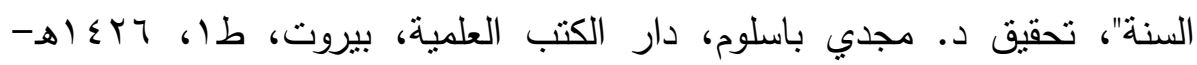
.0

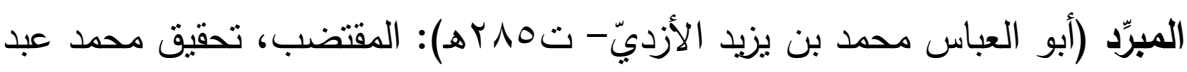
الخالق عضيمة، عالم الكتب، بيروت، د. ط، د. ت. EY. 
محمد البوطيّ: من روائع القرآن، مؤسسة الرسالة، بيروت، 999 ام.

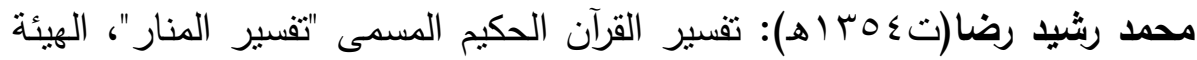
المصرية العامة للكتاب، . 99 (م. محمد العبد: النَّصّ والخطاب والاتصال، الأكاديمية الحديثة للكتاب الجامعيّ،

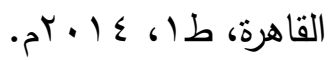
محمد الغزاليّ: نحو تفسير موضوعيّ لسور القرآن الكريم، دار الثروق، طء، $\cdot{ }^{\prime} \cdot \cdots$ محمد الطاهر بن عاثور: تفسير التحرير والتتوير اتحرير المعنى السديد وتتوير العقل الجديد من تفسير الكتاب المجيده، الدار التونسية للنشر ، تونس، ع 9 ام. محمود أحمد نحلة: آفاق جديدة في البحث اللغويّ المعاصر ، دار المعرفة الجامعية، $\cdot r^{\prime} \cdot r$ مسعود صحراويّ: التداولية عند العلماء العرب- دراسة تداولية لظاهرة الأفعال الكلامية في التراث اللسانيّ العربيّ، دار الطليعة للطباعة والنشر، طاه هبه بيروت، . . . O ابن هشام (جمال الدين عبد الله بن يوسف بن أحمد- ت (آVهـ): مغني اللبيب عن

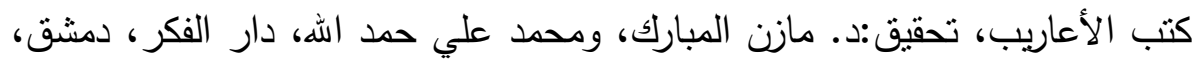
ط7، 1910 أبو هلال العسكريّ (الحسن بن عبد الله بن سهل - ت 90سه): الفروق اللغوية، حققه: محمد إبراهيم سليم، دار العلم والثقافة للنشر والتوزيع، القاهرة، مصر، د.ت. يحيى بن حمزة العلويّ- ته \ـهـ: الطراز لأسرار البلاغة ، المكتبة العصرية،

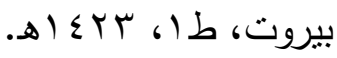




\section{ثانيًا - الأجنبية}

Austin. J. L. (1962): How to do Things with Words, Harvard University Press.

Bussmann. H. (1996): Dictionary of Language and Linguistics. Translated and edited by Trauth. G.P. and Kazzazi, K. Routledge. London\& New York.

Cohen, L.J. (1974): "Speech acts" Current trends in linguistics, Vol.12.

Geis, M, L. (1997): Speech act and Conversational Interaction. Cambridge University Press.

Green, K. \& Lebhan, J. (1996): Critical Theory\& practice, (London/New York)

Helbig, G. (1990): Entwicklung der Sprachwissenschaft seit 1970, Westdeutscher Verlag GmbH. Opladen.

Leech, G. (1983): Principles of Pragmatics. Group limited. London. Leech, G \& Thomas, J. (1990): Language, Meaning and context: Pragmatics, in: Collinge, N.E (ed): An Encyclopedia of Language. Routledge London and New York.

Levinson. S. C. (1983): Pragmatics. Cambridge University Press Lyons. J. (1996): Linguistic Semantics. An Introduction. Cambridge University Press.

Searle. J. R. (1969): Speech Acts. An Essay in the philosophy of language. Cambridge University Press.

Searle. J. R. (1972).: The Philosophy of Language, Oxford University Press.UK..

Searle. J. R. (1981): Expression and Meaning. Studies in the Theory of Speech Acts, Cambridge University Press.

Thomas. J. (1996): Meaning in Interaction. An Introduction to Pragmatics.

Longman, London and New York

Vanderveken, D. (1990): Meaning and Speech Acts. Vol.1:

Principles of Language, Cambridge University, Press. 